Portland State University

PDXScholar

\title{
Wedding Bands and Marriage Bans: A History of Oregon's Racial Intermarriage Statutes and the Impact on Indian Interracial Nuptials
}

Matthew Aeldun Charles Smith

Portland State University

Follow this and additional works at: https://pdxscholar.library.pdx.edu/open_access_etds

Part of the History Commons

Let us know how access to this document benefits you.

\section{Recommended Citation}

Smith, Matthew Aeldun Charles, "Wedding Bands and Marriage Bans: A History of Oregon's Racial Intermarriage Statutes and the Impact on Indian Interracial Nuptials" (1997). Dissertations and Theses. Paper 5723.

https://doi.org/10.15760/etd.7596

This Thesis is brought to you for free and open access. It has been accepted for inclusion in Dissertations and Theses by an authorized administrator of PDXScholar. Please contact us if we can make this document more accessible: pdxscholar@pdx.edu. 
THESIS APPROVAL

The abstract and thesis of Matthew Aeldun Charles Smith for the Master of Arts in History were presented May 5, 1997, and accepted by the thesis committee and the department.

COMMITTEE APPROVALS :

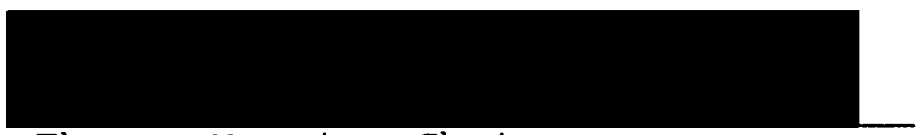

$$
\text { Thomas Morris, Chair }
$$

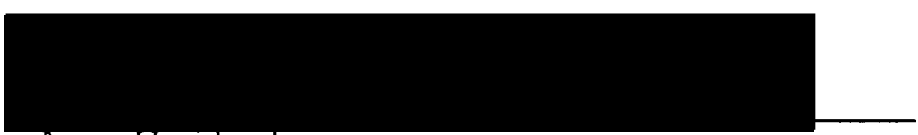

Ann welke1

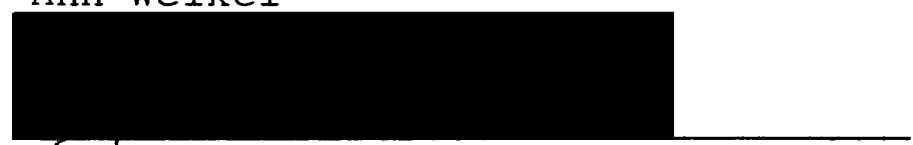

Gergion Dodds



Darrell Millner, Representative of the Office of Graduate Studies

DEPARTMENT APPROVAL:

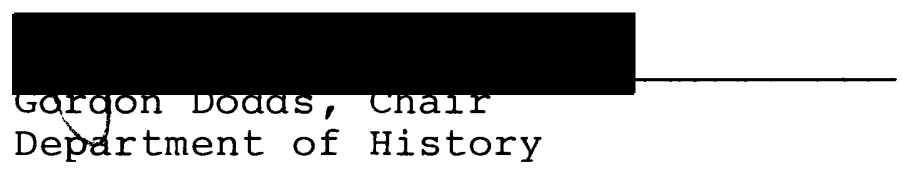



ACCEPTED FOR PORTLAND STATE UNIVERSITY BY THE LIBRARY

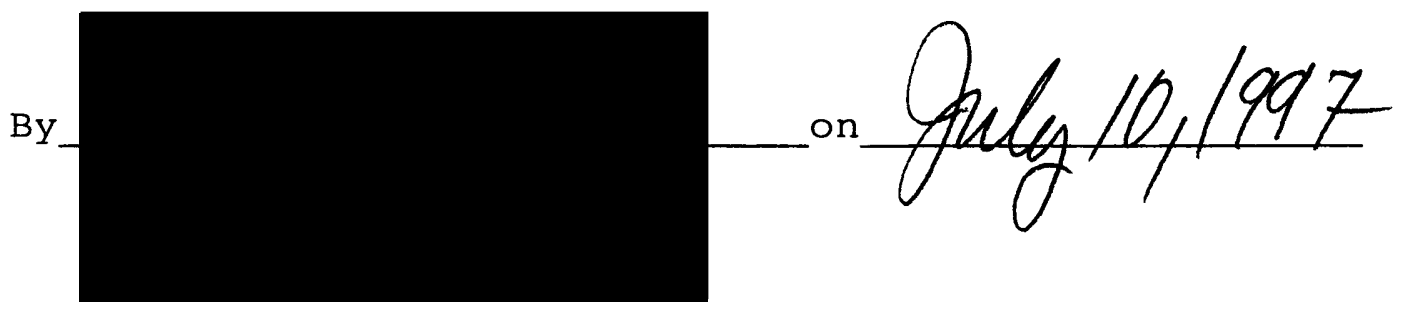




\section{ABSTRACT}

An abstract of the thesis of Matthew Aeldun Charles Smith for the Master of Arts in History presented May 5, 1997.

Title: Wedding Bands and Marriage Bans: A History of Oregon's Racial Intermarriage statutes and the Impact on Indian Interracial Nuptials.

Beginning in the late eighteenth century, the first contacts between white and Indian cultures in oregon quickly secured marriages between the European and American traders and trappers and indigenous women. These unions sustained economic alliances and nurtured cultural links.

But the opening of the Oregon Trail brought an influx of white men and women from America's Middle West who stored more than supplies in their wagons. They transported racial beliefs which subjugated all non-whites to an inferior status. Laws were passed by this generation of pioneers in each governmental period -- provisional, territorial and statehood -- which codified a wide spectrum of prejudicial thoughts. This thesis focuses on the interracial marriage bans which were passed in the $1860 \mathrm{~s}$, with special consideration given to the 1866 law which stated that it was a criminal offense for a white person to marry a black, Chinese or Hawaiian person of one-fourth or more blood, or an Indian of more than one-half blood. 
This sweeping marriage ban was not repealed until 1951.

The purpose of this study is to examine white-Indian marriage in the context of this law which existed for eighty-five years. Primary sources are utilized extensively for each of the chapters. Catholic church records underscore the prevalence of white-Indian marriages which existed throughout the region in the years leading up to the $1860 \mathrm{~s}$

The legislative tussle waged over the bill in the 1866 session is complimented by newspaper accounts and Oregon census materials. These documents show clearly how the creation of the comprehensive intermarriage law was steeped in a mixture of national issues and local motivations. This combination of national and local impulses was repeated during the repeal process in 1951 . Valuable office of Indian Affairs documents from the mid-1880s to the mid-1930s unearth plentiful evidence of interracial marriage during these years. Indian censuses carried out on Oregon's four major reservations preserve a fifty-year legacy of marriages which flouted the law. In conclusion, this study finds that despite the presence of an Oregon law which levied criminal sanctions against people who even attempted a banned marriage, whites and Indians continued to solemnize their relationships. 
WEDDING BANDS AND MARRIAGE BANS:

A HISTORY OF OREGON'S RACIAL INTERMARRIAGE STATUTES AND THE IMPACT ON INDIAN INTERRACIAL NUPTIALS

$$
\text { by }
$$

MATTHEW AELDUN CHARLES SMITH

A thesis submitted in partial fulfillment of the requirements for the degree of

\author{
MASTER OF ARTS \\ in \\ HISTORY
}

Portland State University

1997 
TABLE OF CONTENTS

PAGE

INTRODUCTION ...........................

CHAPTER

I LOVE BEFORE THE LAW: INTERRACIAL NUPTIALS PRIOR TO OREGON'S MARRIAGE BANS..............

II THE ADVENT OF OREGON'S RACIAL INTERMARRIAGE LAWS ...................

III RESERVATIONS WITH MARRIAGE: RACIAL INTERMARRIAGE IN THE OREGON INDIAN CENSUS



IV REPEAL AND VALIDATION IN THE 1950s: THE TERMINATION OF OREGON'S RACIAL INTERMARRIAGE BANS ..................

CONCLUSION

BIBLIOGRAPHY

APPENDIX A CROSSING THE COLUMBIA: OREGON INTERRACIAL MARRIAGES IN CLARK COUNTY...

APPENDIX B A DISGUSTING SPECTACLE: PORTLAND'S RESPONSE TO THE AOKI-EMERY WEDDING..... 
INTRODUCTION

Tales of interracial marriage in the histories of pioneer Oregon commonly portray the unions as pragmatic liaisons between fur company trappers bereft of white women and Indian women forging economic ties. With the onset of the Oregon Trail and the imposition of the reservation system, white society and Indian culture are segregated in these stories. Oversimplified by these accounts, the implication is that white-Indian marriage was merely a vestige of a bygone era. "The writings about Indian-white relations and Indian cultures in Oregon have done little justice to fact," writes Stephen Dow Beckham in The Indians of Western Oregon: This Land Was Theirs. "Most historians have not examined the manuscript sources in the national archives nor have they read the monographs on Indian culture written by anthropologists over the last century." 1 In finding this oversight a national trend, two noted scholars contend that "perhaps the greatest potential for quantitative methods in Indian history lies in the realm of social history." 2 Contemporary issues "would especially profit from a reorientation of research issues." ${ }^{3}$

My thesis attempts to redress some of these oversights by examining white-Indian marriage in the context of Oregon's racial intermarriage bans. Broadening an 1862 law, the comprehensive bill passed in 1866 banned marriage 
between Indians of more than one-half blood and whites. Blacks, Chinese and Hawaiians of one-fourth or more blood also were barred from marrying whites under this criminal statute.

The first chapter is devoted to examining interracial marriage in Oregon until 1860. In the first chapter I aim to illustrate the extensive marriage trends that were readily apparent to legislators in the late $1860 \mathrm{~s}$. Combining the Catholic Church Records of the Pacific Northwest, census figures and land claims, I will highlight how interracial marriages became an ingrained part of the economic, political and social life of pioneer Oregon. From anonymous French-Canadian farmers to architects of Oregon's destiny, dozens of settlers built lasting bonds with their Native American wives.

Weaving a thread through this period -- from provisional government to territorial government and statehood -- was a generation of laws which discriminated against blacks, Chinese, Indians, Hawaiians and mulattoes. The second chapter studies the increasingly hostile climate that oregon fostered towards interracial marriages in the 1860s. From the Legislature to the editorial offices to the general populace, Oregonians solidified a disgust with the practice. The repercussions of the Civil War reverberated through the Oregon Legislature in 1866. Democrats embittered by the passage of the Fourteenth Amendment utilized Union Republican opposition to 
interracial marriage. Documents illustrate that despite the unmistakably confrontational tone, settlers of various backgrounds and Native Americans continued to marry.

The heart of the third chapter comes from the Indian censuses kept on an annual basis by the agents of oregon's four major reservations. The censuses run on microfilm from the 1880s to the 1930s and offer a sizable body of evidence confirming racial intermarriage. The chapter opens with an overview of Indian policy in Oregon which culminated in consignment to reservations. I have also included several events which affected intermarriage during this period on all four reservations.

The reservations did create a segregated oregon. "By the 1880s Oregon Indians, for the white majority, were literally out of sight and out of mind, consigned to fringe regions, unworthy in their impotence even of hatred. They had become a sacrifice to the cultural conservatism of white Americans who transplanted racism in the wagon train to the new land." 4 But federal policies beginning with the Dawes Act in 1887 opened up reservation land to a major non-Indian presence. I will examine the reservations -Klamath, Siletz, Umatilla and Warm Springs -- in alphabetical and chronological order. The Klamath Reservation receives special attention because of the considerable evidence of Indian and non-Indian marriage. Similar to the impulses which dictated the 1866 debates, a potent mixture of national and local trends 
precipitated the repeal of the interracial marriage laws in 1951. Chapter four examines this symbiotic repeal process under the guidance of Governor Douglas McKay. Nationally, the political climate in the wake of World War II favored transferring Indian control from federal authorities to state officials. Locally, civil rights legislation reversed much of Oregon's discriminatory legacy. While the main focus of this thesis is white-Indian interracial marriage, I have added two appendixes which more directly address racial groups other than Native Americans. The first appendix examines the practice of Oregon couples marrying in Washington, a state which never placed racial provisions in its marriage code. A study of clark County marriage records for random years in the 1920s, 1930s and 1940s finds couples who would have faced criminal sanction for attempting to marry in oregon.

The second appendix outlines the imbroglio which erupted in the spring of 1909 when an interracial California couple announced their intention to marry in oregon. The wedding plans engendered vitriolic newspaper accounts.

For almost ninety years, Oregon defined interracial marriage as a criminal act. Despite the repressive ban and a majority mind-set which perpetuated segregation, racial intermarriage continued throughout the law's existence, each ceremony testifying to perpetual cultural links forged by couples who married in love and with affection. 


\section{CHAPTER I}

LOVE BEFORE THE LAW:

INTERRACIAL NUPTIALS PRIOR TO OREGON'S MARRIAGE BANS

From the advent of the Pacific Northwest fur trade in the 1780 s and the influx of European and American adventurers, white pioneers and Native American women formed sexual relationships. Captain Robert Gray's discovery of the Columbia River in 1792 elicited excitement and the travels of Meriwether Lewis and William Clark bolstered aspirations of westward expansion. The subsequent proliferation of trading companies in the $1810 \mathrm{~s}$ and $1820 \mathrm{~s}$ intensified economic rivalries between competitors. European and American traders and businessmen vied for closer ties with the well-established tribes of the Northwest. "By marriage to the daughter of a chief or other prominent Indian, the European trader was often able to assure himself of the friendship and commerce of that man, his family, and his village, tribe or group," writes John Hussey . $^{1}$

Indian chiefs sought the economic partnership of the new sojourners. "It is important to emphasize that the Indians initially encouraged the formation of marriage alliances between their women and the European traders," writes Sylvia Van Kirk in $\frac{\text { Many Tender Ties, }}{5}{ }^{2}$ an examination 
of women in the fur-trade society from 1670 to 1870 .

"The Indian viewed marriage in an integrated social and economic context; a marital alliance created a reciprocal social bond which served to consolidate his economic relationship with a stranger. Thus, through marriage, the trader was drawn into the Indian's kinship circle. And in return for giving the traders sexual and domestic rights to their women, the Indians expected reciprocal privileges such as free access to the posts and provisions. The marriage of a daughter to a fur trader brought Brestige and the promise of security to an Indian family."

Marriage effectively bridged the two cultures. In present- day northwest Oregon and southwest Washington the rival Clatsop and Chinook tribes frequently intermarried with whites in the first decades of the nineteenth century. ${ }^{4}$ "These relationships not only helped to cement a better relationship between the whites and natives, but they also were a great influence on the history of Oregon," wrote Emma Gene Miller in a history of Clatsop County. 5 The daughter of Chief Cobaway of the Clatsops, Celiast, served as a conciliatory presence during disputes and misunderstandings, especially in the late $1820 \mathrm{~s}$ when an argument over the ownership of washed up cargo erupted between the Clatsops and the Hudson's Bay Company. ${ }^{6}$ Married to a white man regarded as the first teacher in Oregon, Celiast mediated between the sparring forces, helping achieve a peaceful remedy. 7 Just to the north of the Columbia River, Chief Concomly of the rival Chinooks saw his family marry whites on an extensive basis. 8

By the 1820s, when the Hudson's Bay Company expanded operations to the Pacific coast, custom and precedent 
sanctioned intermarriage between white men and Native American women. The Company solidified a stranglehold on trade in the Northwest by merging with several opposition companies. In anticipation of border disputes and international squabbles, Hudson's Bay officials shifted Oregon headquarters to the east from Fort George, or the present city of Astoria at the mouth of the Columbia River, to a spot on the northern bank of the river. Fort Vancouver was completed in the spring of $1825 .^{9}$

Before the 1820s marriages were either celebrated by the tribal customs of the region's diverse Indian populations or conducted as "country marriages," as interracial marriages which were a hybrid of European pomp and Indian custom were regularly called. In many of these relationships, the European trader paid the father of the bride a dowry. The marriage could be ended at any time by either party. According to John Hussey, after 1821 the Hudson's Bay Company initiated a marriage contract to bolster the tenuous quality of the country marriage. 10 Still living in a region without recognized religious authorities, the couples were bound by a marriage contract that declared the woman to be a "'lawful' wife [and] specified the economic responsibilities of the husband, and they often required the couple to be remarried by a clergyman when an opportunity presented itself," writes Hussey. 11

Dr. John McLoughlin, the company's chief factor for 7 
the Columbia District from 1824 to 1845 , loomed as the dominating presence in the region. He was directly involved in intermarriage because in late 1811 or early 1812 he married by local custom Margaret McKay, whose mother was described as either a "full-blooded Indian" or a "half breed."12 Richard Montgomery in The White-Headed Eagle: John McLoughlin - Builder of an Empire delves into supposition when assessing McLoughlin's desire to marry a woman of Indian heritage. "One wonders whether John, despite his admiration for Margaret's charm and innate wisdom, may not have thought twice before taking a wife of Indian blood," Montgomery writes. "Such marriages, however, were the order of the day. They were, in fact, the only ones. Those early traders knew only too well that white girls could not stand the rough life at far-flung outposts whereas Indian women and half breeds knew no other."13 Montgomery's description of their relationship possesses traces of condescension. "Margaret, with her Indian heritage, could follow the doctor wherever he went, and he could not have found anywhere a more loyal or helpful companion. Indeed she was to prove a model of self-sacrifice and wifely devotion."14

In Royal Family of the Columbia: Dr. John McLoughlin and His Family, Alberta Brooks Fogdall describes interracial marriages in pragmatic terms. White women failed to travel to the Pacific Northwest before the $1840 \mathrm{~s}$ in any great numbers so, Fogdall suggests, the unions between white 
men and Native American women materialized out of business-like necessity. "Thus Indian wives were the result of the process of elimination," she concludes. 15 Fogdall pinpoints five advantages from the relationships.

"1. While social life was peculiar due to the absence of white women, it would have been virtually non-existent without Indian wives.

2. Indian wives brought protection to their husbands, since Indian women were less vulnerable to attack from their own race than white women would be.

3. Marriage connections brought business to the white trappers, guaranteeing them a food supply as they traveled.

4. Indian wives helped their husbands to learn and understand the language and customs of various tribes, promoting friendship and goodwill.

5. Indian women were hardier than their Caucasian counterparts, better able to bear childrep and to take care of households in frontier country."

Under McLoughlin's tutelage, marriages between white settlers and Native American women were accorded a reverence which belied the sense that they were simply products of a process of elimination. McLoughlin supervised the approval of marriage certificates. He would issue the certificate, and the record of any certificate was made in the Chief Factor's annual report. 17 "It may be truthfully said that the character of the factors, traders and clerks of the company was, as a rule, so high that the marriage relation, although with women of Indian blood, was held in high respect," writes T.C. Elliott. 18

This innate respect infused the Company's policy whereby desertion of Indian wives was looked upon with 
great disdain by Company representatives. "A company marriage, even though blessed by neither Church nor state, was binding and legal," writes Fogdall. "In a sense the Honourable Company was both church and state providing both legal and moral restrictions for many years."19 McLoughlin reiterated the importance of marriage throughout his tenure. "Years later, at Fort Vancouver, he was not only to set an example of marital fidelity but to compel every man who had taken an Indian wife to treat her exactly as if the Church and state had sanctified the wedding," writes Montgomery. 20

Hubert Howe Bancroft in his History of Oregon captured the spirit of a community intimately linked with Fort Vancouver. Plainly, by 1834 interracial marriage was commonplace:

"Between the fort and the river, on the smooth sloping plain, by a village consisting of thirty or forty log houses, ranged along a single street, [lived] servants of the company, Canadians, half-breeds, and Hawaiians, with a few from Orkney Island. In every house an Indian woman presided as mistress, and the street swarmed with children of mixed blood. Nothing offensive met, the eye: everywhere cleanliness and decorum prevailed."

As the village settled into a pattern of contentment, a missionary from the East entered the willamette Valley south of Fort Vancouver in 1834 to plant the region's first mission. The Methodist Church had ordered Jason Lee to Oregon with the express purpose of Christianizing the Indians. The Catholic- dominated Hudson's Bay Company owned a decade's head start in fostering links with the 
extensive Indian populations in the area. Lee needed a strong stratagem to overcome its predominance.

In Equality on the Oregon Frontier: Jason Lee and

the Methodist Mission, 1834-43, Robert Loewenberg traces Lee's plan to convert the Native Americans of the oregon Territory. Before Lee's appearance, the two types of marriage which existed in the area were tribal marriage or the Company-sponsored contract marriage. One glance at a contract certificate, Cornelius Brosnan declares in Jason Lee: Prophet of the New Oregon, "recalls for a later generation the primitive conditions that prevailed in those early days when Jason Lee helped to break the solitude of that distant region." 22 In the search for successful selling points, "Jason Lee discovered 'a proper system' when he realized that the institution of Christian marriage might be used as a device for converting Indians," writes Loewenberg. 23 Lee sought to utilize weddings as a means of converting whites and Native Americans by example. "The missionary's marriage would inspire emulation among the white-Indian couples living in the valley. These couples, with familial and other links to the Indians, would in turn influence the heathen," writes Loewenberg. 24

For those white-Indian couples who chose marriage, Lee planned a dual purpose. "First these couples would be examples to surrounding Indians; for this reason Lee ardently believed [the couples'] 'influence must be corrected," writes Loewenberg. "Second, settlers with 
Indian wives had prestige among the Indians and Lee hoped to exploit it for the missionary ends by winning the confidence of the settlers and then using it to reach the Indians." 25

However, some religious figures recoiled at intermarriages, such as the Anglican Reverend Herbert Beaver and his wife, Jane, who arrived at Fort Vancouver in September 1836. "She scorned the part-native and Indian wives of the gentlemen at the Fort whom she considered were living in sin because the Beavers would not recognize the native rites of marriage," writes Vera Martin Lynch in Free Land for Free Men: A Story of Clackamas County. 26

Soon Lee was joined in the sacred battle for souls. Subsidized by the Hudson's Bay Company, which hoped to lure former employees onto willamette Valley land, two priests journeyed to Oregon and became the first official Catholic presence in the region. 27 Arriving at Fort Vancouver in November 1838, Father Francois Norbert Blanchet and Father Modest Demers then secured a mission in Champoeg in the Willamette Valley early the next year. ${ }^{2}$ Blanchet and Demers immediately began to replace marriage by certificate with recognized religious ceremonies that even the Beavers could not scorn.

Upon their arrival in the region, Blanchet and Demers kept church records of births, deaths and, most importantly for this study, marriages. Chronicled as the Catholic Church Records of the Pacific Northwest, the annals kept 
by the two pioneering priests and their successors began in the late 1830s and continued until the early twentieth century. Starting in the Fort Vancouver region, the records followed the path of priest and pioneer alike as they ventured forth to other areas in present-day oregon. My examination of these Catholic Church records illustrates a proliferation of interracial marriages when the priests arrived. Between 1838 and 1855 the entries for Vancouver verify eighty-four marriages between white settlers and full Native American women. 29 Twelve more marriages occurred between white men and women of one-half or less Indian ancestry. 30 Combined with additional information from later land claims and census information, the Vancouver marriages which begin in December 1838 challenge the concept that white-Indian marriages were simply calculated business ventures or an expedient diversion until white women arrived in the region.

Beginning in December 1838, these weddings fastened many of the region's dynamic and respected economic, social and political pioneers to the Oregon landscape. ${ }^{31}$ The ceremonies engendered understanding between diverse cultures of American and Canadian farmers, trappers, and former Hudson's Bay employees and dozens of Native American tribes. Although these marriages provoked unease and rebuke for many of the generation which traveled to Oregon in the $1840 \mathrm{~s}$ as the first wave on the Oregon Trail, the numerous biographical portraits underscore the deep and lengthy 
bonds between husband and wife which resounded for generations despite racist rhetoric or restrictive law.

On December 27, 1838, Amable Petit married "Susanne, natural daughter of Thomas Twakka and of a woman of the country."32 They were the fourth couple married at Fort Vancouver and the third on that day. Father Blanchet led the ceremony which legitimized seventeen-month-old Henri. According to his claim made for the oregon Donation Land Act of 1850, Petit was born in Canada in 1819 and married another woman, Emely, in February 1846.33 susanne's fate is unknown, but petit settled a land claim in Marion county in February 1850 and was granted citizenship in November 1853.34

All three marriages performed on December 29 stipulated that the ceremonies were conducted with the consent of James Douglas, commander of Fort Vancouver. 35 Each marriage legitimized children born to the couples. Basile Piorier married "Louise, woman of the Dalles," but he also recognized three children ranging in age from fifteen to seven-years-old from an earlier relationship with an Indian woman. 36 The two other ceremonies of that day showed the diversity of tribal affiliation as the brides were "of the nation of Indians of the Cascades" and a cree woman. 37

The newly arrived presence of Blanchet and Demers prompted a plethora of marriages, with twenty-three ceremonies in January 1839 alone. The weddings developed into communal events for the Fort as thirteen marriages 
were celebrated on January 21 and a further seven were solemnized on January $28 .{ }^{38}$ Twentyone of the twenty-three marriages were between white men and full Indian women. The vast majority of men marrying in the month were farmers from Canada. The international flavor was underscored with a French day laborer and two Irish farmers serving as grooms.

On January 21, a Canadian farmer named Francois Rivet married "Therese," a Flathead Indian, in a ceremony which joined in wedlock a couple together since at least 1814.39 Father Blanchet, who used the term "teteplatte," which meant Flathead, to describe the bride, also officiated over the legitimization of their two sons, Antoine, aged twenty-five, and Joseph, aged twenty-three. Francois and Therese secured a land claim in Marion county by the end of the year. According to Donation Land Claim records, Francois was born in Canada in 1759.40 A February 7, 1877 letter from B.F. Harding of Fairfield in Marion County to Owen Wade, the registrar of the Oregon City Land Office, provides colorful yet apocryphal insight into his journey to Oregon. "He came to this country with Lewis and clark. started from st. Louis in the spring of 1804 . He stopped in the spokan Country and never returned to Mo.." "writes Harding. 41 Instead he settled a land claim on December 30,1839 and became a naturalized citizen in september 1852 , just months before his death at the age of 94.42 Two children were legitimized when Canadian Louis 
Labonte and "Marguerite," a Clatsop Indian, married on January 21. 43 A third child, "Victorie, daughter of bride with Mr. McMullin," was also recognized by the couple. 44 Labonte was born in 1783 and settled his land claim in October 1837. The land claim entry was a year off when it stipulated that the marriage occurred in January 1840.45 Eleven years later Labonte received American citizenship in Yamhill county. 46

Six children were legitimized on January 21 when Joseph Delard, a Canadian farmer, wed "Lisette." 47 However Delard's land claim does not suggest a lengthy union between the parents of the children. Born in Canada in 1794, Delard arrived in Oregon in 1815 and settled his claim in Marion County in October 1835.48 The claim noted that he married Mary Conissaint Piorier on January $18,1842.49$ The claim included a copy of the marriage certificate signed by Father Antoine Langlois, Priest of St. Paul's, located in the Willamette Valley. Delard became a citizen in October 1864.50

The legacy of Etienne Lucier, who was one of the twentythree men married in January 1839, in the development of organized government in Oregon is immeasurable. In Men of Champoeg, a worthy biographical sketch written by Caroline Dobbs about the pioneers who voted in favor of provisional government in May 1843, Lucier stands out as a pivotal player. Several of the French-Canadians, including Lucier, were wary of American government because 
of rumors circulating that the United States imposed heavy duties, even going so far as to place a tax on windows. 51 The Company and Catholic priests hosted several meetings leading up to May 1843 to discourage Canadian participation in the community organization. 52 "The story goes that the cause might have even then been lost had not Lucier broken away from the other French Canadians who had been instructed to vote 'no' and cast the deciding affirmative vote with the Americans," Dobbs writes. 53

Efforts to stitch together Lucier's biography highlight some of the difficulties in utilizing assorted pioneer-era records. The Catholic Church records described a January 23, 1839 marriage between "Etienne Lussier," a Canadian farmer and "Josephte." 54 The wedding legitimized six children ranging from twenty-five-years-old to six months. The Donation Land Claim entry listed the spelling of his name as "Etiene Lucier," and noted that he was born in Canada in 1785 and settled his tract in November 1831.55 However, in regard to a wedding, the entry said that Lucier married "Margaret" in July 1840.56 The 1860 census of Marion County listed a Margaret Lucier as a fifty-year-old Indian born in oregon and the owner of three thousand dollars in real estate and three hundred and fifty dollars in her personal estate. 57 Two sons, Peter, aged sixteen, and Etienne, aged fifteen, were too young to be the legitimized children. 58 They lived with their mother as farmers but did not receive any racial distinction in the 
census category

The same day, January 23, 1839, Pierre Depot and "Marguierite," a Klamath Indian, were married. 59 The Oregon Donation Land Claim stated that Depot was born in Canada in either 1799 or 1800.60 Depot's trouble with dates even included his wedding day. He wrote that he wed Margaret in either "December 1835 or $1838 . " 61$ However he was sure that he secured his claim on Christmas Day, 1839. Margaret died in January 1850 , leaving three children. Depot collected his naturalized citizenship in september 1851.62

Father Blanchet and Demers married seven interracial couples on January 28, 1839, including Joseph Gervais, a Canadian farmer and "Marguerite," a clatsop Indian. 63 Seven children were legitimized during the ceremony for the couple who soon settled a land claim. Furthermore on January 28, another signer of the Champoeg provisional government pact was married. According to Dobbs, William McCarty arrived in 1834 from Ireland with aspirations of becoming a farmer. "He married a daughter of Chief carcowan of the Chehalis."64 Her name was Charlotte when she was listed in the church records. 65

Father Blanchet remained busy as he performed extensive mass nuptials, with eleven Hudson's Bay employees marrying Indian women on February 11, 1839. All eleven men were Canadian but the brides illustrated the breadth of tribal affiliation created between Native Americans and the white pioneers and settlers. The women were described by Blanchet 
as members of the following nations: Cathlamet, Chinook, Kawachens, Makah, Nez Perce, and Sookes. 66

Throughout 1839 church records continued to document weddings, with a mixture of Hudson's Bay employees and Canadian farmers and hunters marrying local Native American women. On June 10, Demers married "Peter Wagner," a Company worker from Canada and "Marie."67 The ceremony legitimized three children. In the 1860 census for Marion County, "Peter Waggoner," a sixty-four-year-old farmer born in Canada was living with Mary, a sixty-year-old Indian born in British America. 68 Peter possessed three thousand dollars in real estate and three hundred dollars in his personal estate. 69

The Vancouver church records had a gap between the middle of 1839 and December 1841 when no marriages were listed. When the records resumed in November 1842 for St. James Church in Vancouver, marriages dotted the ledger, with the most prominent Hudson's Bay official seeking church sanction. On November 19, Dr. John McLoughlin and Margaret renewed "their consent of marriage." 70

Even though interracial marriages continued, the number of weddings never resembled the frequency of 1839 , when forty-four marriages were solemnized. The figures for the rest of the Vancouver church records showed three marriages in 1842, seven in 1843, six in each year between 1844 and 1846 , three in 1847 and eight ceremonies spread over the remaining seven years. 71 Even though the nuptials 
flagged, many white men sought Native American brides after the immigration of white women. The legacy of Antoine Azure provided an example of this choice. Azure married "Lisette," a Klamath "of age of infidel parents" on January 29, 1844. 72 Seven months after Lisette's death in October 1845 he married "Marie Madeline," an Indian from the Cascade Mountains. 73 The final listing in the Vancouver records on February 12, 1855 noted that Azure married "Catherine," a Shoshoni "living at Fort Vancouver." 74

The decline in interracial marriages at the Vancouver church was partly the result of shifting demographics as many of the Company's former employees became farmers in the fertile willamette Valley. As these men moved south into the valley, new Catholic parishes were initiated and the records of these parishes documented interracial marriages. The parish of St. Paul was established in 1839 and included all of French Prairie. ${ }^{75}$ Blanchet moved into a humble log chapel in October of that year. 76 Between 1839 and 1847 , st. Paul recorded twenty-seven marriages between white men and full Indian women. 77 A further twenty-six marriages were solemnized between couples with at least one partner having mixed parentage, which meant a Canadian or American father and an Indian mother. 78 Widowed upon the death of Margaret in January 1840, Joseph Gervais was remarried by Father Blanchet in July to a Chinook Indian, "Marie, formerly of Vancouver."79 Etienne Lucier was also remarried in st. Paul parish. 20 
Jospehte was buried in the st. Paul cemetery on January 12,1840 after dying the day before at the age of forty. 80 On August $10, \mathrm{Blanchet}$ wed Lucier and a Chinook woman named Marie. 81

During the time the Catholic Church initiated marriage ceremonies and Methodist missionaries like Lee attempted to sway religious loyalties through nuptials, Oregon underwent a political gestation. The American settlers who ventured to Oregon in the early 1840 s envisioned an Oregon with undying ties and loyalties to the United States. French-Canadians were increasingly outnumbered by American pioneers in the valley. Many of the old guard either bristled at British influence or were resigned to the inevitable American link. A spirit of conciliation towards the Native Americans was waning. By 1843 immigrants who would not countenance marriages between whites and Indians arrived in droves. After 1843 the region was populated with many people eager to disparage amicable white and Indian relations. In Katherine Berry Judson's account of Oregon during this time, interracial marriage was the key issue in an 1843 Willamette Valley incident involving several of the new immigrants which was defused before causing irreparable damage.

"Forty of these rougher men planned to drive all the white men out of the valley who had Indian wives. Most of these men were French-Canadian but some were American. The French-Canadians had been there many years; their lands were well cultivated, and their cabins good. It would be an easy way for lawless men to get a good cabin and farm. The FrenchCanadians, who were part Indian, got their 
guns ready, and so did many of the Americans who had Indian wives. But the better element refused to join these law-breakers. There were not enough of them to 8 force the 'squaw-men' out, and so the plot fell through." 82

Instead of guns, the old and the new in oregon battled with words over the dilemma of initiating a provisional government. In May 1843 some 100 settlers and pioneers convened in Champoeg to determine the type of government the Oregon region would adopt. "This was the time and place for the final decision between the factions opposing and favoring the establishment of a government -- a test of strength between the French Canadians and Hudson's Bay adherents and the Americans," writes Dobbs. 83 Dobbs sketches personal descriptions of fifty-two men who voted for provisional government. She breaks the group into eight factions based on their arrival in the willamette Valley. In examining the biographical information of the members of these factions, it is clear that fifteen of the fifty-two supporters of provisional government were married to Native American women. 84 This twenty-eight percent of the total was most heavily concentrated in two of the categories, the earliest settlers and the mountain men, and accounted for eleven of the marriages. The earliest settlers were men who arrived before 1832 and five of the seven earliest settlers wed Native American women. Two of these men, Etienne Lucier and William McCarty, were listed in the Catholic Church records. 85 All six of the pioneers classified by Dobbs as "Mountain 
Men" married Native American women, including Joseph Gale, who was named to the provisional government's first executive committee. 86 Arguably the most famous of the "Mountain Men," Joe Meek, the legendary hunter and trapper and future United States marshal for Oregon, was indebted to his wife. "Once his life was saved by a beautiful Shoshone girl, who afterwards became his wife, or was so called until a Bannock arrow ended her life."87

Yet these eleven men were vastly outnumbered by men who would not breach the lines of interracial marriage. With the creation of the provisional government in 1843, Oregon adopted laws which discriminated against several racial groups. While the Organic code of the provisional government in 1843 possessed a ban on slavery, the code included a provision which bestowed voting rights on free male descendants of white men, thereby denying the vote to blacks and most Native Americans. 88

The next year the provisional law took a much harsher tone towards blacks when the oregon authorities passed an exclusion law in June 1844 which prohibited slavery and required all blacks to leave the territory within three years. 89

When a new executive committee met in the same month, the trio of governors exhibited racial precepts in agreement with the new immigrant ferment. The executive committee consisted of an Englishman who had lived in Oregon since 1835, a fur company worker seen as "well fitted to represent 23 
the conservative and moral element of colonial society," and an immigrant from $1843 .{ }^{90}$ when the committee sent a letter to the Oregon legislative assembly, the prospects for conciliatory white and Indian relationships seemed damaged. Coming three months after the Cockstock Affair, the June 18, 1844 missive called for the adoption of the laws of Iowa for the territory. A sizable number of the Oregon settlers came from the Middle West, notably the Ohio and Mississippi river valleys. ${ }^{91}$ They transported many of the tenets of Middle West constitutions. The executive committee's letter included proposals which jeopardized white-Indian unions and foreshadowed more intense efforts to extinguish intermarriage. They recommended "that a law be enacted for the punishment of offenders inciting the Indians against the whites, and regulating the intercourse of the whites among the Indians of this colony." 92

The first Oregon law on marriage made no mention of race. In fact, the 1843 law was quite broad in its scope. The marriage section of the provisional government stipulated that:

"All male persons of the age of sixteen years and upwards and all Females of the age of fourteen years and upwards shall have the right of engaging in Marriage provided that where either of the parties shall be under twenty one years of age, the consent of the Parents or Guardians of such Minors shall be necessary to the validity of such matrimonial engagement." 93

The law added that every ordained minister and justice 
of the peace in the region could solemnize "Marriages according to Law." 94 Then all marriages would be recorded by the Territorial Recorder within one month of the wedding. Despite a growing unease with interracial relationships and the intermingling of white and Indian populations, racial stipulations would not enter Oregon's marriage strictures for another generation.

Southern Oregon faced a similar transformation as the one visited upon the Willamette Valley. Acceptance of interracial unions diminished. In the 1830s, interracial marriages contributed to the Hudson's Bay's success in the southern part of the territory. Norman Dennis Schlesser describes, in Bastion of Empire: The Hudson's Bay Company's Fort Umpqua, the integral economic and social bonds forged through interracial marriage based at the first white settlement in southern Oregon. Michel LaFramboise, clerk of the Company's Southern Party married a woman whose father was a French-Canadian and whose mother was a full Indian. In addition to legitimizing their ten-month-old child in the 1839 ceremony LaFramboise also recognized his twenty-month-old child by another woman. ${ }^{95}$ LaFramboise "would be characterized as an ex-officio member of the Umpqua tribes and through the good offices of his wives he could travel in safety through the region." 96

Schlesser describes Jean Baptiste Gagnier as the best known of the French Canadians who served at Fort Umpqua. ${ }^{97}$ He was postmaster and resident in charge of Indian Trade 25 
from 1836 to 1841. "The fact that Jean Baptiste Gagnier according to the custom of mountain men of his day had taken the daughter of a prominent Umpqua as his wife no doubt went far to promote amicable relations between Hudson's Bay men and the Indians of the lower valley," Schlesser sums up. 98

But unions such as Gagnier's fell in esteem in a racial climate where tolerance for interracial marriages faltered during the 1840s. "Before the coming of large numbers of settlers into the region with all their prejudices against mixed marriages many happy alliances between whites and Indians had been formed," writes Schlesser. 99

By 1845 the population in St. Paul parish grew so quickly that the southern section of French Prairie received a pastor of its own. 100 The southern section, which was named Grand Prairie, became the parish of st. Louis. Beginning in 1845, St. Louis priests solemnized twelve marriages between white men and full Indian women over the next thirteen years, with the last of the twelve celebrated on August 23, 1858.101 All twelve men were French-Canadians and the women came from a variety of tribes, including Saste, Snake, and Walla Walla. ${ }^{102}$ An additional forty-five nuptials between January 1845 and January 1863 were performed when at least one of the parties was listed as one-half Indian. Thirty of these marriages were between white men, predominantly French-Canadians, and women noted as one-half Indian. Twelve of the 
forty-five marriages brought together couples who both had a white father and an Indian mother. In three of the forty-five, a man with a white father and an Indian mother married a full white woman. 103

In 1846 oregon City became the seat of the newly established Archdiocese and was graced with an impressive church overlooking the Willamette River. Records were kept for Oregon City beginning in 1842 and they produced scant evidence of racial intermarriage. ${ }^{104}$ In March 1842, Father Demers wed two French-Canadians to a Nisqually and a Chinook woman, respectively. ${ }^{105}$ The Oregon City scrolls added three more marriages, with each of these between a full white man and an Indian woman of mixed parentage. ${ }^{106}$

In the second volume of st. Paul records, which spanned the years 1847 to 1864 and included the northern section of French Prairie, interracial marriages were much more prevalent. Thirteen marriages were conducted between white men and full Indian women, with a further thirty-three ceremonies joining couples where at least one party had a white parent and a Native American parent. ${ }^{107}$ On July 2, 1848, Louis Vassal, aged twenty two, married Catherine who was "baptized the same day of infidel parents and already married or allied to the said bridegroom since several years in the manner of the infidels of the country."108 The marriage recognized two children, ages two and three months.

When the Oregon Territory was created in 1848, several 27 
of the adopted racial laws replicated provisional statutes. A territorial exclusion law was passed in much the same manner as the earlier version. Both laws gained support in the aftermath of highly publicized murders of white people. While the 1844 law was ratified in the wake of the Cockstock Affair, the territorial law was motivated by the Whitman massacre of November 1847, in which fourteen white settlers were murdered at their Wailatapu mission by Cayuse Indians. "Although no black people were involved in this incident, racist legislation was again seen as a cure for white anxieties," writes Elizabeth McLagan in A Peculiar Paradise. 109 The following preamable to the 1849 exclusion bill encapsulated the perception among many white settlers of a fomenting racial insurrection against them. The preamble also offered an explanation as to why lawmakers singled out blacks even though the motivating incident involved Native Americans.

- . situated as the people of oregon are, in the midst of an Indian population, it would be highly dangerous to allow free negroes and mulattoes to reside in the territory or to intermix with the Indians, instilling in their "piffds feelings of hostility against the white race

\section{The first federal census conducted for the oregon} Territory in 1850 contains evidence of racial intermarriage, and while the practice was becoming less common in the region, the count for the areas in present-day Oregon seemed to underestimate the extent of intermarriage. The 1850 census recorded forty-seven interracial marriages, with 
the vast majority of the couples living in Lewis County, which would become part of Washington Territory in 1853. ${ }^{111}$ Thirty marriages were listed in Lewis County, with the remaining seventeen spread between several counties which became part of the state of oregon. ${ }^{112}$ Located on the Pacific Coast, Benton County recorded one marriage between a white man and a black woman. Running almost the entire length of Oregon's Columbia River border, Clackamas County listed eight marriages, with four between white men and Indian women and four between white men and mulatto women. In the northwestern corner of the region, Clatsop County listed three white-Indian couples while Washington County had four white-Indian marriages.

Even though it was the hub of the French-Canadian community, Marion County included only one interracial marriage. The husband was F.B. Mathier, a thirty-one-year-old farmer from Canada with four thousand dollars in real estate. La Rose Mathier was a twenty-two-year-old woman born in Oregon who was listed as "HB," a reference to "half-breed" or mixed parentage. 113 Three children, ages six to two, had no racial designation. Yamhill County, which had become a popular farming spot for many of the French-Canadians, listed no interracial marriages. 114

The 1850s witnessed an upsurge in white-Indian hostilities. Increasing encroachment by settlers on Indian land fueled tensions. The Oregon Donation Land Act of 29 
1850 precipitated much of the unease. An important part of the Act gave land to settlers who already lived in Oregon. The Act stated that any eighteen-year-old white male, including "American half-breed Indians" who cultivated a land claim for four consecutive years before December 1, 1850 received 320 acres. All other racial categories were disqualified from the land rush. The recipient had to be a citizen or file their intention for citizenship by December 1, 1851.115 If he was married, then his wife received another 320 acres. A married couple stood to hold 640 acres. 116 In all, 7,432 claims were made under the provisions of the Donation Act in present-day Oregon.

In southern Oregon the Rogue River Wars from 1850 to 1855 pitted gold hungry miners against Native Americans who also felt embattled by the swarms of pioneers who were enticed by the Donation Land Act. By the middle of the decade, the federal government instituted a reservation system which consigned thousands of Native Americans to partitioned parcels of land. Indians were corralled into four reservations in present-day Oregon.

Several Catholic Church parishes and missions which initiated services in the $1850 \mathrm{~s}$ illustrated this separation as interracial marriages rarely graced the record books. The earliest Catholic Church records of the Roseburg mission and the Jacksonville mission in southwestern Oregon offer evidence that this separation spread to the altar. Beginning in 1853, the Roseburg register did not list a 
single interracial marriage conducted by a Catholic priest. 118 The Jacksonville entries began in 1854 and did not record any interracial marriages. 119

The burgeoning city of Portland founded the parish of the Immaculate Conception in 1853. For nearly thirty years, it would serve as Portland's only Catholic church. 120 The collected records of the church spread over an eighteen-year-period and exhibited few interracial marriages. On September 10, 1853 Louis Nepucingue married Lisette, a Klickitat woman. ${ }^{121}$ More than a decade passed until November 1863 when John Laurence, whose parents were both from "the island of San Antonia" married Louisa Donaville, whose parents were recorded as "both Indians."122 On December 20, 1864 Henry Sunshine, who was born in Prussia, married Nancy Mary Glenn, whose parents were listed as Indians. 123

Court documents help illuminate the prevalence of interracial unions and the controversy they generated in the 1850s. In December 1854, the Territorial Supreme Court in Oregon settled a land dispute in Vandolf v. Otis, which centered on the racial status of Louis Vandolf's wife. Louis Vandolf was born in Canada in 1798 and married Catherine on September 14,1840 in Champoeg. ${ }^{124}$ The couple settled their land claim on Christmas Day, 1842. Vandolf became a citizen on september $8,1851.125$ Daniel otis was born in Vermont in 1821, arrived in Oregon in the fall of 1852, and settled his family's claim in November 1855.126 
The dispute between the two hinged on the Donation Land Act. Otis admitted that he tried to siphon off the southern portion of Vandolf's tract because Vandolf was married to a Native American. 127 The case before the court was to determine if Vandolf was entitled to the entire 640 acres if his wife, who remained unnamed in the opinion, was classified as an "Indian." In an eloquent opinion Chief Justice George Williams affirmed the Vandolf's entire land claim and seemingly validated intermarriage. Williams placed Catherine Vandolf's status as a wife above any other consideration, including race.

"If the wife of a competent settler has no rights under the donation act, because she is not 'white,' then it is perfectly certain that the wife of such a settler has no rights under said act, unless she is over the age of eighteen years, for the law, in one breath, prescribes both age and color. Such a conclusion would not only contravene the obvious meaning and uniform construction of said act, but would destroy the hifherto unquestioned right to a large amount of property."

Then Williams addressed the married relationship between the Vandolf's as compared to a white couple and conclusively supported the sanctity of the Vandolf's fourteen-year marriage.

"Now, is not a man, legally married to an Indian woman, as such a 'married man,' to all intents and purposes, as though his wife were the 'fairest of the fair?' Is not an Indian woman, married to a white male citizen of the United States, 'a wife in every sense of the law?' If two women are married in the same way to the same sort of men, can it be said that one is a 'wife' because she is white and other is not a 'wife' because she is copper-colored? Are the children of a white man and an Indian woman, legally, married, bastards, because their mother is not white?" 32 
Williams rebuffed the argument from the otis legal camp that Catherine was an alien and so subsequently she could not receive her husband's property or claim any authority to administer the parcel of land.

"The conclusion is irresistible that an Indian woman, married to a 'settler,' is a 'wife,' within the meaning of the donation act, and therefore, on account of her wifeship, entitled to one-half of her husband's claim. But it is said that an Indian woman is an alien, and therefore, has no inheritable blood, and cannot be endowed of her husband's estate. Admitting this to be true, is wholly immaterial, and avails nothing in this case. The question here is, not what would be the rights of an Indian wife in the estate of a deceased husband, at common law, but what are her rights under the donation act, as the wife of a living legal settler . . But this absurd doctrine that one has inheritable blood, and another has not, is exploded here, for by our law aliens can purchase, inherit, hold and convey property as if they were native-born citizens."

The Chief Justice tackled the paradox that if the United States government currently was implementing reservation policies which separated whites and Native Americans, then why would Congress draft legislation which sanctioned further racial integration through marriage? Williams countered that intermarriage in Oregon was common knowledge and Congress, if the august body so desired, possessed the ability to produce legislation which forbid interracial couples from collecting 640 acres.

"When the donation act was passed, Congress must have known that many of the early settlers of Oregon had married Indian women: and if it was not intended to place men so married upon the same footing "with other married men, why did not Congress say so - . "

Williams understood the importance of his decision by noting that many people hoped he would decide against 33 
the right of Indian wives to possess land under the act. Public opinion did not sway the jurist.

"Doubtless it would be better if land so held belonged to white men; so it would be better if the lands of the indolent were in the hands of the industrious; but such considerations, if worthy of notice at all, cannot weigh against the plain meaning and effect of the statutes." 12

In summing up the case, Williams believed the purity of the donation act's promise far outweighed the avarice of a fellow homesteader. Besides, the Chief Justice seemed to define the issue in social terms.

"Indian women, as the wives of white men, and the offspring of such marriages, are unavoidably a part of our people, and it is better that they should have property and homes, than that they shơuld be worthless and wandering vagabonds in the country."

The Williams opinion earned a swift reaction from The Oregon Statesman. The Salem newspaper was edited by Asahel Bush, who two years earlier helped form the Democratic Party in Oregon. On December 5, 1854, an unsigned editorial next to the unabridged text of Williams' judgment praised the Chief Justice for his thorough contemplation of the matter. "This decision is an important one to the whole of Oregon and Washington Territories; but it is especially so to this county," the anonymous author intoned. 139 The importance may have come from sheer numbers. "We presume there are more Indian wives of lawful settlers in Marion than in all the other counties in the Territory," the author wrote. "And we are informed that nearly if not quite all (some say all) of those claims have been jumped within the past few days, upon the strength 
of a report that Judge Williams had decided against the right of squaws to hold."135 But while the editorial lauded Williams for his prudence, the statesman contended that the decision contravened white wishes in the Territory and suggested that future efforts would allay the rumblings of the settlers.

"We doubt not that many of the settlers upon the French Prairie would prefer that the lands held by these Indian wives should pass into the hands of white settlers, and believe it would be to the advantage of the community and country that they should do so. Still we do not think they would wish to see the law violated $i^{\prime}$ effecting this desired change. Time will effect it."

The editorial writer proved prescient as both the Oregon and Washington territories increasingly spoke and acted in ways which denigrated racial intermarriage. In January 1855, a month after the Williams decision, the Washington Territory authorities passed a law voiding any marriage "between a white person and an Indian who was more than a half blood."137 In the same month, the oregon territorial legislators debated a bill which would exclude "negroes" and "mulattoes" from settling in the territory. A member of the Territorial House of Representatives infused his call for exclusion with a diatribe lauding racial purity that forecast an ominous fate for racial intermarriage. Even though Native Americans were not the target of the bill and the legislator's enmity rested with blacks, the perception of racial pollution through sexual liaisons was clear. 
"Niggers . . should never be allowed to mingle with whites. They would amalgamate and raise a most miserable race of human beings. . . If niggers are allowed to come among us and mingle with the whites, it will cause a perfect state of pollution . . I don't see that we should eggualize ourselves with them by letting them come among us." 138

When Oregon achieved statehood in 1857, the voters adopted a constitution filled with racial stipulations, including an exclusion provision banning all blacks and mulattoes. 139 Hostility was directed towards Hawaiians as well. Commonly refered to as "Kanakas," Hawaiians ventured to Oregon in the early nineteenth century as employees of the fur companies, especially the Hudson's Bay Company. By 1845, the provisional government levied a tax on employers for every Hawaiian worker, with a higher tax imposed on newly arrived employees. ${ }^{140}$ Hawaiians were not eligible for property under the provisions of the Donation Land Act and the state constitution banned the Islanders from voting. The Chinese pioneers who ventured to Oregon in the $1850 \mathrm{~s}$ to work as miners were barred from obtaining citizenship, voting, owning property and working mining claims. 141

The oregon constitution was hardly an original document, with the constitutions of Indiana, Iowa and Michigan serving as the principal models. 142 Those states were a great influence because the settlers in Oregon came predominantly from the Mississippi Valley. The evidence of social conservatism of the later settlers from the Mississippi Valley had been on display since the immigration 
of the 1840s and became codified in the constitution. "Nowhere was this conservatism more evident than in the provisions reflecting racial or ethnic prejudice," writes Gordon Dodds. 143 
1 Stephen Dow Beckham, The Indians of Western Oregon: This Land was Theirs (Coos Bay, Oregon: Arago Books, 1977), p. 220 .

2 Melissa Meyer and Russell Thornton, "Indians and the Numbers Game: Quantitative Methods in Native American History," in New Directions in American Indian History, ed. Colin Calloway (Norman: University of Oklahoma Press, $1988)$, p. 17 .

3 Ibid., p. 19

4 Gordon Dodds, Oregon: A History (New York: W.W. Norton, $1977)$, p. 114 .

\section{ENDNOTES FOR CHAPTER I}

1 John Hussey, "The Women of Fort Vancouver," Oregon Historical Quarterly 92 (Fall 1991): pp. 266-67.

2 Sylvia Van Kirk, Many Tender Ties: Women in Fur-Trade Society, 1670-1870 (Norman: University of Oklahoma Press, 1980), p. 28. Similar information on white and Indian attitudes to interracial marriage can be found in Jennifer Brown, Strangers in Blood: Fur Trade Company Families in Indian Country (Vancouver: University of British Columbia Press, 1980) and Yvonne Hajda, "Regional Social Organization in the Greater Lower Columbia, 1792-1830" (Ph.D. diss., University of Washington, 1984). Hajda notes that "though marriages were very likely undertaken in order to 'strengthen their commercial relations,' the only example is a white-Indian marriage, not one between Indians." (p. 180).

3 Ibid., pp. 28-29.

4 Emma Gene Miller, Clatsop County, Oregon: Its History, Legends, and Industries (Portland: Binford and Mort, 1958), pp. 57 and 64 .

5 Ibid., p. 56

6 Ibid.

7 Ibid., p. 57

8 Ibid., p. 64 
9 Gordon Dodds, The American Northwest: A History of Oregon and Washington (Arlington Heights, Illinois: The Forum Press, 1986), p. 40 .

10 Hussey, p. 268.

11 Ibid.

12 Richard Montgomery, The White-Headed Eagle: John McLoughlin, Builder of an Empire (New York: The Macmillan Company, 1934), p. 11 .

13 Ibid., p. 27

14 Ibid.

15 Alberta Brooks Fogdall, Royal Family of the Columbia: Dr. John McLoughlin and His Family (Portland: Binford and Mort, 1978), p. 71 .

16 Ibid.

17 T.C. Elliott, "A Hudson's Bay Company Marriage

Certificate," Oregon Historical Quarterly 10 (September $1909):$ p. 325 .

18 Ibid.

19 Fogdall, p. 71

20 Montgomery, p. 30 .

21 Hubert Howe Bancroft, History of Oregon, vol. 29 of The Works of Hubert Howe Bancroft (San Francisco: The History Company, 1886), p. 9 .

22 Cornelius Brosnan, Jason Lee: Prophet of the New Oregon (New York: The Macmillan Company, 1932), p. 89.

23 Robert Loewenberg, Equality on the Oregon Frontier: Jason Lee and the Methodist Mission, 1834-1843 (Seattle: University of Washington Press, 1976), p. 112.

24 Ibid., p. 113

25 Ibid., p. 119

26 Vera Martin Lynch, Free Land for Free Men: A Story of Clackamas County (Portland: Artline Publishing, 1973), p. 122 .

27 Dodds, American Northwest, p. 58 . 
28 Montgomery, p. 253.

29 Harriet Duncan Munnick, ed., Catholic Church Records of the Pacific Northwest, Vancouver, vol. 1 and 2, (St. Paul, Oregon: French Prairie Press, 1972).

30 Ibid.

31 Ibid.

32 Munnick, Vancouver, vol. 1, 27 December 1838.

33 Genealogical Forum of Portland, Oregon, Genealogical Material in Oregon Donation Land Claims, vol. 1, (Portland: Genealogical Forum of Portland, 1962), claim no. 1821 .

34 Ibid.

35 Munnick, Vancouver, vol. 1, 29 December 1838.

36 Ibid.

37 Ibid.

38 Ibid., 21 January and 28 January 1839.

39 Ibid., 21 January 1839.

40 Genealogical Forum, vol. 1, claim no. 2197.

41 Ibid. The notion that Rivet traveled with Lewis and clark seems apocryphal.

42 Ibid.

43 Munnick, Vancouver, vol. 1, 21 January 1839.

44 Ibid.

45 Genealogical Forum, vol. 1, claim no. 1797.

46 Ibid.

47 Munnick, Vancouver, vol. 1, 21 January 1839.

48 Genealogical Forum, vol. 1, claim no. 2239.

49 Ibid.

50 Ibid. 
51 Charles Carey, General History of Oregon Prior to 1861, vol. 1, (Portland: Metropolitan Press, 1935), p. 331 .

52 John Hussey, Champoeg: Place of Transition, (Portland: Oregon Historical Society, 1967), p. 149 .

53 Caroline Dobbs, Men of Champoeg, (Portland: Metropolitan Press, 1932), p. 17 .

54 Munnick, Vancouver, vol. 1, 23 January 1839.

55 Genealogical Forum, vol. 1, claim no. 1745.

56 Ibid.

57 Bureau of the Census, Eighth Census of the United States, 1860, Oregon, (Manuscript Census Schedules). All future references to the census will note MCS.

58 Ibid.

59 Munnick, Vancouver, vol. 1, 23 January 1839.

60 Genealogical Form, vol. 1, claim no. 1839.

61 Ibid.

62 Ibid.

63 Munnick, Vancouver, vol. 1, 28 January 1839.

64 Dobbs, p. 24 .

65 Munnick, Vancouver, vol. 1, 28 January 1839.

66 Ibid., 11 February 1839.

67 Ibid., 10 June 1839.

68 MCS, 1860 .

69 Ibid.

70 Munnick, Vancouver, vol. 2, 19 November 1842.

71 Ibid., Vancouver, vol. 2 .

72 Ibid., Vancouver, vol. 2, 29 January 1844 .

73 Ibid., Vancouver, vol. 2, 13 April 1846.

74 Ibid., Vancouver, vol. 2, 12 February 1855. 
75 Harriet Duncan Munnick, ed., Catholic Church Records of the Pacific Northwest, st. Louis, vol. 1, (Portland: Binford and Mort, 1982), p. xv.

76 Harriet Duncan Munnick, ed., Catholic Church Records of the Pacific Northwest, st. Paul, vol. 1, (Portland: Binford and Mort, 1979), p. xviii.

77 Munnick, st. Paul, vol. 1.

78 Ibid.

79 Munnick, st. Paul, vol. 1, 6 July 1840.

80 Ibid., 12 January 1840.

81 Ibid., 10 August 1840 .

82 Katherine Berry Judson, Early Days in Old Oregon (Portland: Metropolitan Press, 1935), pp. 158-59.

83 Dobbs, p. 1 .

84 Ibid., p. 28 .

85 Ibid.

86 Ibid., p. 77. The original executive committee of Oregon's provisional government was a three-person body which served as the equivalent of a governor in the fledgling government.

87 S.A. Clarke, Pioneer Days of Oregon History, vol. 2, (Portland: J.K. Gill Company, 1905), p. 261.

88 Elizabeth McLagan, A Peculiar Paradise: A History of Blacks in Oregon (Portland: The Georgian Press, 1980), p. 25 .

89 McLagan contends that the "Cockstock Affair" prompted the exlusion law. McLagan writes that in Oregon City in March 1844, a Native American named Cockstock swore vengeance on George Winslow, an African American who allegedly never delivered a promised horse as Cockstock's payment for farm labor. Winslow sold the horse and his farm to a black man named James Saules. After Saules refused to turn over the horse, Cockstock stole the animal, and was trailed by Elijah White, the local Indian agent. When cockstock was confronted, a gun battle ensued and a legislative clerk was killed in the blaze of bullets. Still bristling from the incident months later, the Oregon authorities passed an exclusion law in June 1844 which prohibited slavery and required all 
blacks to leave the territory within three years.

90 Bancroft, vol. 29, p. 428 .

91 McLagan, p. 24 .

92 Bancroft, vol. 29, p. 428 .

93 David Duniway and Neil Riggs, "Oregon Archives, 1841-1843," Oregon Historical Quarterly, 60 (June 1959): p. 278 .

94 Ibid.

95 Munnick, Vancouver, vol. 1, p. 428.

96 Norman Dennis Schlesser, Bastion of Empire: The Hudson's Bay Company's Fort Umpqua, (Oakland: Oakland Publishing, 1973), p. 28 .

97 Ibid., p. 26.

98 Ibid., p. 27.

99 Ibid.

100 Munnick, St. Louis, vol. 1, p. xv .

101 Ibid., vol. 1 .

102 Ibid.

103 Ibid.

104 Harriet Duncan Munnick, ed., Catholic Church Records of the Pacific Northwest, Oregon City, (Portland: Binford and Mort, 1984 .

105 Ibid., 30 March 1842.

106 Ibid. The Oregon City Catholic Church records show scant evidence of intermarriage. Catholicism was dwarfed by Protestantism in a town which swelled with the immigrants of 1842 and 1843. Oregon City was the location of the first Protestant church built on the Pacific. Racial intermarriag was probably not particularly fancied by these new arrivals.

Furthermore, white-Indian relations were strained for Oregon City inhabitants. A Portland Oregonian story on Oregon City in the March 11, 1900 edition helps illustrate the uneasy relations: "For many years the village was kept in a ferment of excitement by the 
fear of Indians and by the Indians themselves. Peace was secured with the savages only at intervals, and most of the fighting forces were raised at Oregon City."

107 Munnick, St. Paul, vol. 2 .

108 Ibid., 2 July 1848.

109 McLagan, p. 26.

110 Ibid. The exclusion law was on the Oregon books from 1849 to 1854. The law was repealed through a legislative oversight during a massive revision of territorial laws. Attempts to revive the exclusion law before statehood failed. (pp. 27-28).

111 Bureau of the Census, Seventh Census of the United States, 1850, Oregon, (Manuscript Census Schedules). While the provisional and territorial government censuses were kept during the years from 1842 to 1859 , these censuses did not include any racial information. In many cases only males older than twenty-one were actually listed in the rolls.

112 Ibid.

113 Ibid.

114 Ibid.

115 Harlow Zinser Head, "The Oregon Donation Claims and Their Patterns" (Ph.D. diss., University of Oregon, $1971)$, p. 20 .

116 Ibid., p. 22. For those people not settled in Oregon, then any new land recipient had to be a white, American citizen who was at least twenty-one years old and came to Oregon between December 1, 1850 and December 1, 1853. This recipient could receive 160 acres of land and a married couple could receive 320 acres.

117 Ibid., p. 25

118 Harriet Duncan Munnick, ed., Catholic Church Records of the Pacific Northwest, Roseburg, (Portland: Binford and Mort, 1986).

119 Harriet Duncan Munnick, ed., Catholic Church Records of the Pacific Northwest, Jacksonville, (Portland: Binford and Mort, 1984).

120 Harriet Duncan Munnick, ed., Catholic Church Records of the Pacific Northwest, Portland, (Portland: Binford 44 
and Mort, 1986).

121 Ibid., 10 september 1853.

122 Ibid., 25 November 1863.

123 Ibid., 20 December 1864. While there were no racial intermarriages listed in the Portland register after the anti-miscegenation law passed, an entry from January 29, 1867 described a child of mixed parents. Two-monthold Therese was baptized by her parents, Catherine "an Indian woman" and "Charley, an American."

124 Munnick, St. Paul, vol. 1, 14 June 1841. The entry noted that "Louis Vandal" and an Indian woman named "Catherine" were married on that day. Two children, ages seven and two, were legitimized by the ceremony.

125 Genealogical Forum, vol. 1, claim no. 4698.

126 Ibid.

127 Vandolf v. Otis, 1 Or. 153 (1854), p. 154 .

128 Ibid.

129 Ibid., p. 156

130 Ibid.

131 Ibid.

132 Ibid., p. 157

133 Ibid.

134 The Oregon Statesman, 5 December 1854, p. 2 .

135 Ibid.

136 Ibid.

137 Robert Ruby and John Brown, Indians of the Pacific Northwest: A History (Norman: University of Oklahoma Press, 1981), p. 148.

138 Robert Johannsen, Frontier Politics and the Sectional Conflict: The Pacific Northwest on the Eve of the Civil War (Seattle: University of Washington Press, 1955), p. 23 .

139 McLagan, p. 28. Slavery was illegal under the constitution. The state's exclusion clause was not 
repealed formally until 1926 .

140 Dodds, American Northwest, p. 83.

141 Ibid., p. 84 .

142 Dorothy Johansen and Charles Gates, Empire of the Columbia: A History of the Pacific Northwest (New York: Harper and Row, 1957), p. 263.

143 Gordon Dodds, Oregon, p. 100. 
THE ADVENT OF OREGON'S RACIAL INTERMARRIAGE LAWS

At the dawn of the $1860 \mathrm{~s}$, Oregon possessed a sizable body of law and custom which splintered the races. Yet, the 1860 census for Oregon contained an unexpected upsurge in the number of interracial couples living in the state. The census recorded sixty-seven interracial couples spread throughout the state and hundreds of interracial children born to those parents. 1 Comparatively the 1850 figures found only seventeen interracial couples in areas which would become the state of oregon. ${ }^{2}$ Both Catholic Church records and the prevailing attitudes of the post-1840 settlers pointed towards a decline in the number of interracial couples chronicled in the 1860 census. However, one can conclude that the census takers were more conscientious in 1860 in categorizing people by race. Furthermore, given the miniscule number of white-Indian households found in the willamette Valley region in the 1850 census, it seems clear that the actual number of interracial unions was noticeably undervalued.

Southern Oregon hosted a sizable pocket of interracial relationships. Twenty-eight couples involved a white man and an Indian woman, five marriages were between a white 
man and a mulatto woman while an additional two marriages were between a black man and an Indian woman. Coos county on the southwestern coast had eight interracial couples, all between white men and Indian women. None of these couples were made up of the earliest settlers as all but one of the brides were under the age of twenty-four. 3

A typical listing showed David Wall, a twenty-nine-year-old laborer born in Ohio, married to Mary Wall, a seventeen-year-old "Indian" born in Oregon. Two children, ages four and three, were listed as Indian and were both born in Oregon. 4 None of the husbands were French-Canadians. Instead, two were born in Germany, with the others from Illinois, Maine, Michigan, and Ohio. The men were either farmers or laborers. 5

A neighbor of Coos County, Curry County was nestled in the southwest corner of the state and recorded nine interracial couples in the 1860 census. 6 Like its northern neighbor, Curry's couples were a newer generation of interracial unions. The grooms were Americans from states such as Maine, New Jersey, New York, Pennsylvania, and Tennessee with an international flavor added by husbands from Prussia and Russia. Their livelihoods were varied as they worked as blacksmiths, farmers, farm laborers, ferrymen, and lumbermen. 7 Elisha Messerney was a twenty-seven-year-old ferryman from Maine. Jane Messerney was a fifteen-year-old Indian born in Oregon and with her occupation listed as housekeeper. In a census slot which 
stated "married within year," both Messerney's had a check. 8

The largest county in size in western Oregon, Douglas County recorded five marriages between white men and Indian women. 9 Several of the couples had lived in Oregon for decades but one couple came together after the immigration flurry of the 1840s. Thomas Brown was a forty-year-old farmer from Scotland who was married to Sarah, a twenty-two-year-old Indian born in Oregon. 10 They had two sons, ages two and two months. Brown's real estate value was ten thousand dollars and his personal estate was worth nearly three thousand dollars. 11

Just a few years before it was swallowed up by Douglas County in a round of county redistricting, Umpqua county totaled three interracial marriages, with two listed between a white man and an Indian woman. Umpqua County also documented a white-mulatto couple. George Mansell was a thirty-one-year-old hotelkeeper from England married to "Anetta," a nineteen-year-old woman born in Mississippi and listed as "m" in the color category. Two children, ages two years and four months, were also listed as "m."12 Bordering California, Oregon's remaining southwestern counties, Jackson and Josephine, both displayed a diversity in their interracial unions. In the Jackson and Josephine scrolls, the term "mulatto" was used. Seven interracial couples lived in Jackson County and in four of the marriages the women married to white men were described as " $m$ " in the color category. 13 The children from those marriages 49 
were 1isted as "m" as well. But in the two white-Indian marriages, the children were listed as Indian. ${ }^{14}$ Samuel Furman was a thirty-four-year-old blacksmith born in Kentucky while his wife was Drusilla Furman, aged twenty, who was born in Tennessee and listed as "m."15 The couples three children, who ranged from four years to ten months, were listed as "m."16 Another Jackson County couple were E.J. Langley, a twenty-five-year-old miner from England and "Mrs. Langley," a twenty-two-year-old Indian born in oregon. 17 Their eight-month-old son was listed as an Indian. There was also one marriage listed between a black man and an Indian woman.

In Josephine County the use of " $m$ " carried a different connotation with two of the three interracial couples. In the case of Joseph Louise, a black fifty-one-year-old barber from England, and his thirty-year-old Indian wife Lucy, their three children, aged eleven to four, were listed as "m."18 Yet the one-year-old daughter of Thomas Moore, a twenty-six-year-old white farm laborer, and Lucy, his twenty-year-old Indian wife, was listed as "m."19

In the regions near the willamette valley corridor, Washington County cited four white-Indian marriages while Multnomah County listed one white-Indian marriage and one blackIndian marriage. 20 wasco county in north central Oregon listed eight couples with a white husband and an Indian wife. 21 All eight men were farmers. The women were housekeepers. 
Located in the heart of the French-Canadian community and home to many Americans amenable to interracial marriage, Marion County saw a considerable rise in the reported marriages from the 1850 figures. Fourteen marriages were listed between white men and Indian women. 22 Nine of the men were born in Canada, four were born in the United States, and the final groom was born in England. The majority of the men were over fifty-years-of-age. In addition, three more couples were made up of French-Canadian men and women listed as one-half Indian. 23 In one marriage a French-Canadian was married to a woman listed as "m" and their four pre-teen children were recorded as "m."24 In the 1862 session an Oregon Legislature dominated by the Union Party, a coterie of Republicans and pro-Union Democrats, passed two major pieces of racist legislation. The state instituted an annual five-dollar poll tax to be paid by "every Negro, Chinaman, Kanaka, and Mulatto residing within this state." 25 Following the lead of Washington Territory and continuing the trend of racially restrictive laws, the Legislature also adopted a marriage ban. But the statute included only one racial class of Oregonian. In October 1862, the Legislature in a comprehensive section on marriage prohibited the nuptials of polygamists, first cousins and "when either of the parties is a white person and the other is a negro or person of one-fourth or more negro blood."26 The law declared that anyone who solemnized a prohibited marriage faced 51 
up to a year in the penitentiary and up to a one hundred dollar fine. Governor Addison Gibbs signed the bill into law on October 15. Legislators not only criminalized this type of miscegenation but added the ban to the civil code section outlining marriage contracts.

The first attempt to expand the scope of the law occurred during a special session in December 1865 when the Legislature ratified the Thirteenth Amendment to the United States Constitution, which abolished slavery. The December 18 Oregon Statesman noted that Representative George Lawson, a Republican from Yamhill County, introduced House Bill 14 which provided "penalties for intermarriage of white persons with negroes, mulattoes, chinese, kanakas, etc., or any person having one-eighth or more of each blood."27 The bill did not pass but sentiments were more favorable in the next regular session.

Oregon's Fourth Legislative Session bristled with tension and acrimony. The twenty-four Republicans and their allies, still under the banner of the Union Party, held a slim advantage over the nineteen Democrats in the House. 28 The Senate also favored the Republicans by a margin of seventeen to seven. With America restructuring itself in the wake of the Civil War, the dominating issue in the fall of 1866 was the ratification vote on the Fourteenth Amendment. The amendment vested citizenship in former slaves and strengthened federal sovereignty over the state's affairs. Punctuated by intense constitutional 
questions, apocalyptic racist diatribes and a massive partisan battle, the Oregon Legislature tackled the amendment in early september. The constitutional imbroglio coursed through the fourth session, permeating many of the debates.

The Senate debates over the amendment reached a crescendo on September 14. "It will inflict an injury on southern people which is an equal injury to the people of Oregon," said Senator W.D. Jeffries, a Polk County Democrat. "Here it will raise Chinamen and Indians to an equality with the whites. . the day which witnesses the equalization of the races here will also witness the disruption of our Republic [sic] Government."29

Senator H.C. Huston, a Democrat from Lane County, complained that the constitutional amendment circumvented the Oregon Constitution by granting citizenship to blacks and Chinese. "Now it is sought to place the inferior races upon an equality with the superior; to make a mongrel people; to place a negro or greasy Chinaman on the same level with Grant the hero and Johnson the incorruptible Chief Magistrate." 30

Despite the heated rhetoric, the senate passed the resolution to ratify the constitutional amendment by thirteen votes to nine. 31 In the weeks following the constitutional amendment tussles, a bill banning a plethora of interracial marriages provided a platform to once again speak out on crucial racial and political issues. The 
debates on the House floor indicated that many representatives viewed the bill as a chance to reaffirm states' rights and further dictate racial hegemony. Several opposing solons saw the anti-miscegenation law as a repudiation of the federal civil rights bill. The following account illustrates a dramatic episode brimming with racial, sexual and political overtones.

On the morning of September 24, James Gingles, a Republican from Benton County, introduced House Bill 2, a piece of legislation which prohibited the intermarriage of white Oregonians with a host of racial groups. ${ }^{32}$ The racial distinctions in Gingles's original proposal prohibited marriage between a white person and a person having one-fourth or more Chinese, Indian, Kanaka or Negro blood. The bill made intermarriage a criminal offense like the 1862 law. Jail sentences up to a year and monetary fines (increased to a maximum of one thousand dollars) would be levied against anyone who entered into the marriage or performed the ceremony. For the next week-and-a-half the bill moved through the procedural hoops until October 4 when a contentious debate ripped through the House chamber, the spirit of which was captured by an account in the Portland Oregonian.

After consultations with committee members, Gingles proposed that the bill be amended so that it read:

"That hereafter it shall not be lawful, within this state, for any white person, male or female, to intermarry 54 
with any Negro or Chinese or any person having one-fourth or more Negro or Chinese blood, or any person having more than one-half Kanaka or Indian blood, and all such marriages or attempted marriages shall be absolutely null and void."33

Representative George Helm, a Democrat from Iinn County, ridiculed the amendment because "he thought it should prohibit the intermarriage of all persons not entirely of the same blood."34 An unidentified representative cautioned that the bill would contravene the Fourteenth Amendment, but Helm dismissed the concern, noting brusquely that "[the civil rights] law was a disgrace to our statute book, and not entitled to a moment's consideration." 35

W.W. Upton, a Multnomah County Republican, hoped that the law would not invalidate marriages sanctioned before the law's passage. 36 However, he also stated that he "thought the idea that there is any party in the state which favors amalgamation of the races too absurd to demand attention." 37

Still, Upton's reference to current marriages was reiterated by John White, another Multnomah County Republican, who addressed the issue of children of white Oregonian men and Native American women. 38 He advocated the exclusion of people with "light Indian blood" from the strictures of the legislation. 39 White did not expand on the percentage of "Iight Indian blood" which should have excused some from the bill. 40 But he praised these 
multiracial progeny as worthy citizens. "There are a great many people in the state of this class, who are persons of talent and respectability -- some of them educated and highly accomplished. This would be a direct insult to them," White stated. 41

With an understanding of the presence of numerous multiracial families in Oregon and fearing that the anti-miscegenation law contradicted the Fourteenth Amendment, F.G. Lockhart, a Coos County Republican, moved to include the words "not a citizen of the United States" after the word "Indian." 42 However his suggestion was not adopted during the proceedings.

Robert Cochran, a Democrat from Lane County, then challenged White's earlier comments by favoring a strict segregationist line. "Cochran said that if the gentleman from Multnomah [Mr. White] had such fine ladies of color among his constituents he should be in favor of learning them to advance to a higher degree of attainments among their own kind." 43 The Lane County Democrat then provided a direct link between the marriage ban and the recently approved Fourteenth Amendment. "He desired to pass this bill in order to carry out the wish of his constituents, who wish to have the binding force of the civil rights bill tested in the courts." 44

W.A. Starkweather, a Republican from Clackamas County, was not content with simply supporting the marriage prohibitions. "He was in favor of passing a law to 
disenfranchise all white male citizens marrying persons of color," the article noted. 45

Isaac Cox, a Josephine County Democrat, used the debate over the anti-miscegenation law to condemn the constitutional amendment. "It will destroy the rights of the states entirely. Under it, all our acts are null and void. It is just as plain as a sunbeam," Cox said, with the Oregonian noting that the comment aroused "merriment."46 Then Cox agreed with Cochran's earlier charge that Oregon citizens deserved the marriage ban because the courts would overturn the constitutional amendments approved in the wake of the Civil War. 47

But I am in favor of this [anti-miscegenation bill] believing, as I do, that those laws of Congress, and that the late amendments to the Constitution will, in the course of time, be declared null and void. You have interfered with the domestic institutions of the states in one instance and it extends to all instances. When you come down to the truth of the matter, our 4 fegislature does not amount to the snap of your finger."

The defiant oration spurred a heated exchange between the Josephine County Democrat and Upton, the Multnomah County Republican.

"'Does the gentleman hold that it is one of the rights and privileges of a negro to marry a white person?' asked Upton. responded.

'I hold that it is a privilege to marry,' Cox

'For a negro to marry a white person?' Upton inquired again.

'You can make no distinction on account of race or color under the civil riggts bill. It is a right under that bill," Cox stated." 
Then Upton asked Cox for his position on Gingles's "Indian" amendment, but Cox only continued with his sarcastic responses. "I am replying to this thing that you have brought up here to show how ridiculous it is. I can consistently vote for this bill, but the gentleman who voted for the amendment cannot," Cox said. 50

In the October 4 afternoon session, White, Upton's fellow Multnomah County Republican, "moved to strike out all of the first section after the word 'Indian' so as to have the prohibitions stop with persons of full blood." 51 This proposed amendment was questioned by several legislators. J.E.P. Withers, a Lane County legislator with no party affiliation, believed White's suggestion was an attempt to submerge the bill. 52 A Republican from Marion County, J.I.O. Nicklin, urged an uncompromising bill. "The Legislature should pass a strong law to prevent the increase of a mongrel race that even the inferior races are ashamed of," Nicklin said. 53

As the discussion drifted into early evening, Upton highlighted how the debate over the anti-miscegenation bill actually provided legislators with an opportunity once again to argue the merits of the Fourteenth Amendment. "In this case the civil rights bill has been more discussed than the pending bill," Upton noted. "He considered party principles foreign to the bill under consideration." 54

When the speaker called for order, Gingles's amendment was approved. 55 Nine days later, on October 13, the House 58 
approved the marriage ban without a recorded debate by a vote of thirty-two to four. 56 The four representatives who voted against the bill which made marriages between whites and several racial groups illegal were a bipartisan group: two Democrats and two Republicans. Sadly, the vast majority indicated that arrogant beliefs in racial supremacy and purity fostered bipartisan agreement.

The bill entered the senate on october 15, and by the end of the week, the upper chamber passed the anti-miscegenation legislation. 57 Governor George Woods signed the legislation on October 24 and so Oregon instituted a comprehensive "act to prohibit amalgamation and the Intermarriage of Races."58 The entire law read as follows:

"Section 1. Be it enacted by the Legislative Assembly of the state of oregon, That hereafter it shall not be lawful within this state for any white person, male or female, to intermarry with any negro, chinese or any person having one-fourth or more negro, chinese or kanaka blood, or any person having more than one-half Indian blood; and all such marriages, or attempted marriages, shall be absolutely null and void.

Sec. 2. If any white person, negro, chinese, kanaka, or Indian, within the above forbidden degrees, shall knowingly intermarry, or attempt the same, by procuring a solemnization of marriage, under any of the forms or ceremonies legalized in this state, such person, or persons, upon conviction thereof, shall be punished by imprisonment in the penitentiary or county jail, not less than three months, nor more than one year.

Sec. 3. If any person authorized to license marriages, or to solemnize marriages, within this state, shall willfully, or knowingly, license, marry, or attempt to marry, any of the persons above forbidden to marry, such person or persons, upon conviction 
thereof, shall be imprisoned in the penitentiary, or county jail, not less than three months, nor more than one year, and be fined not less than one hundred dollars, nor more than one thousand dollars.

Sec. 4. It shall be the duty of the clerks of the several counties in this state, when applied to for a 'license' to marry, to inquire into the facts, as to whether either of the parties to such proposed marriages comes within the above forbidden degrees, and for this purpose, he may put such applicant on oath, and demand further proof in his discretion; Provided, Such clerk shall not require more than the affidavit of one other disinterested person."

Several of the state's major newspapers printed the entire text of the new marriage law in their roundups of the legislature's work, but the press was largely silent in the runup to the bill's vote. 60 A survey of the state's newspapers in 1865 and 1866 found no editorials or news stories which delved into racial intermarriage, let alone any which expressed chagrin. But as the votes were cast, editorial writers addressed the issue.

On October 8, 1866 an editorial in the Oregon statesman studied the continual controversy over black suffrage. "Thus the African, conspicuous for nothing save degradation, brutality and barbarism, has for nearly half a century convulsed a continent with fretful bickering and stormy contention," wrote the editorial writer. 61 The author continued to examine the black experience in disparaging terms. "White men could fight and fall unnoticed, forsooth, while a negro could not invade a poultry yard without being entitled to a full length portrait in Harper, and a column or so of adulating comment." 62 
The exasperated writer then penned a passage filled with undertones of miscegenation. "strange to say, the people are almost ready to yield the sanctity of their highest prerogative to pollution and dishonor, and clothe a mongrel race with the sovereignty of enlightened freedmen!"63 He continued in a sarcastic tone about voting rights: "It is now plain that the valiant and patriotic negro needs protection, an end which can only be secured by that surest of freedom's bulwarks -- the right of suffrage!" 64

Less than a week later, the Albany state Rights Democrat published its regular legislative column, "Letter from the Capital." Written on October 3 from Salem but not published until ten days later, the column penned by "LISTENER" delivered unblinking evaluations of the politicians. 65 several of the legislators who would speak passionately on the anti-miscegenation bill the next day were evaluated. Race and sexuality were clear targets for the pseudonymous critic. "starkweather is a consistent partisan," wrote the scribe, who added that "[Starkweather] believes a nigger as good as a white
man, would be proud to see the amalgamation of the races,
and especially would be pleased to see the slave in the
South trample upon his master and debauch the daughter,
through personal hostility to the growing enterprise of
a class so much envied by the picayune spirit of New
England, and is therefore consistently opposed to the
Democracy, the old Constitution, liberty and to a republican
form of government."66. For another Republican representative, "LISTENER" 
expressed his contempt with more brevity. "Upton, of Multnomah, is the most rotten and corrupt of any man in the House."67 As a group, legislators like starkweather and Upton riled the columnist into a frenzy. "These men, many of them, were once Democrats; were once friends of their country, but have sold themselves for a price which they have not received. Some of them are in a worse condition than the famed Judas who did receive the thirty pieces of silver; and some of them are daily selling out their country," the writer noted. 68

The next month, the "Letter from the Capital" columnist concluded his roundup with unflinching opinions:

"Of Lockhart, of coos and Curry, I have had occasion to speak heretofore. I could not, perhaps, deal out justice to him were I to make an effort to do so. His record is most inconsistent as a partisan; an Abolitionist by profession and a Radical at heart, fully up to the most extended idea of equalizing the races, he voted against the Constitutional Amendment! Radicals, do you endorse the vote of Lockhart upon that megsure? Democrats, do you believe that he was sincere?

The column ended with a political prayer. "God grant that Olney, and Upton, and Granny Cheneworth, and Hangman Dolph, and Africanus Johnson, and Honest Tom Cornelius will never again be the leaders of the House and Senate, as long as honest men and white men are determined to govern themselves. Men of Oregon, remember the outrages done you at this session." 70

Directly below this column, the state Rights Democrat reprinted an "amusing account of a Northern miscegenation affair" from the Nashville Dispatch and titled the story 62 
"Unprofitable Miscegenation." The story told of the travails of a woman from Indiana who moves to Nashville, Tennessee with her infant and soon needs the attention of a doctor. "Imagine the surprise of the doctor on noticing that the color of the infant did not at all correspond with the complexion of the mother. Kinky hair, flattened nose and thick lips, gave indubitable evidence of African descent."71 After the doctor inquired, the woman said that she left Indiana because of her child, but that she believed mixed race children were not uncommon in Nashville. "Further, she would like to dispose of it (the child) in some manner; could the doctor afford her any assistance in this direction also? 'No madam,' replied the Doctor, 'such property is of no value here now. A few years ago it would have been worth a hundred dollars, but there is no market for it now." 72 The state Rights Democrat added that "we have yet to learn what disposition has been made by the mother of her dusky offspring. The Doctor's dry joke doubtless astonished her."73

Oregon newspapers did not delve into the issue of miscegenation until the Daily oregonian published a lengthy editorial titled "Matrimonial Prospects of the Negro Race" on september 12,1867 . The piece adopted a sardonic tone towards positions like that of the state Rights Democrat.

"It is not easy to see how any one who takes the Democratic view of politics can avoid admitting that the prospects of the negro race for forming advantageous matrimonial alliances are becoming unusually good. Certainly this is the case for it is granted that it would 63 
be of any advantage to the negroes to form conjugal alliances with that class of whites who adhere to the Democratic party. For that class tell us and have told us for many years that the recognition of any rights to the negro race would infallibly lead to enforced social equality and compel white people to marry 'niggers.' The abolition of slavery, it was feared, would produce this direful result. The arming of blacks against the rebels was only putting arms into the hands of 'disgusting niggers' to enable them to enforce mafrimonial alliances with the fair daughters of the land."

The editorial continued to outline the justifications that many in the Democratic movement utilized in order to argue against black freedom. Stirring up potent sexual images was the key to many of these arguments.

"Civil rights were to be feared as a pestilence; for when a negro was endowed with civil rights could he not turn his matrimonial aspirations any whither and compel any alliance he should see fit?"75

When the fear of black lust failed to provoke, then the concept of white passion for interracial unions was bandied about, according to the author. "Occasionally the argument has taken a somewhat different course, and fears have been expressed lest white people, finding legal restraints removed, should neglect attractive persons of their own race and mate only with blacks," the oregonian stated. "This is the true meaning and interpretation of the word 'mongrelize,' and so often finds a place in Democratic literature."76 The editorial writer admitted that this argument was both potent and desperate, yet failed to ever mention that oregon currently had legal restraints on these type of marriages. Instead the writer hardly endorsed intermarriage when he made a cutting remark 
regarding Clark's slave, York.

They talk about 'negro equality' being possible, just as if there were anything like equality, in a social point of view, among different classes of whites; just as if anything like 'equality' in the sense in which they use the term, ever existed or ever could exist in the world. And they talk about the country becoming 'mongrelized,' just as if our people were like those women of the Indian race who were met by Lewis and clark on their Pacific expedition, and who took a very great fancy to the black negro man who accompanied the explorers, making him their preferred favorite above all others. It would be insulting to common intelligence to propose such stuff as many of their journals constantly 5 gem with as argument worthy of serious consideration."

Two weeks later the State Rights Democrat delivered two powerful salvos in the war of words over black suffrage and miscegenation. The first shot was a New York Press reprint which possessed "the ring of the true metal" for racial purity. 78

"Our fathers . . never intended to share their co-partnership with these Indians, any more than with the Chinese or Japanese, our own Pacific ocean neighbgrs. The land was made open and free for Anglo-Saxon."

With veiled references to the constitutional amendments, the Press unequivocally said that white men alone deserved self government. "The white man is the superior man, the dominant man, over the African, the Mongolian, the Esquimaux, or other species, of men, and was designed and destined by God to be so," the paper wrote. 80

"All attempts of our race to share government, and our society with the inferior races of men . . . have been destructive of both races - . Amalgamation is death, both to white, negro men, or Mongolian men. Equality and fraternity with these lower races is against the will of God and God punishes by the destruction of both races all these violations of His Holy Will." 
In the same edition, the state Rights Democrat editor, M. Abbott, tackled black voting rights in an editorial titled "Resisting Fate -- Negro Suffrage." Abbott bemoaned the defeated tone of many of his movement's followers and challenged stalwarts to resist the temptation to give up, and instead he urged them to follow the example of Luther and Patrick Henry. 82 He said all this while unleashing a blistering racist attack on miscegenation.

"When we cease to oppose Negro Suffrage -- when we cease to oppose the inevitable sequence of Social Negro Equality -- when we cease to raise our voice against the intermarriage of the kinky-haired, flat-nosed, thick-lipped, long-heeled, sweet-scented, lazy negro with the Caucasian race -- may our right hand forget its cuphing, and our tongue cleave to the roof of our mouth."

The paper vowed to "fight as long as we live" and prayed for the repeal of "the nefarious laws which a fanatical Congress have placed upon our statute books."84

The September 30 edition of the Salem Daily Record quoted the more sensational segment of the state Rights Democrat's editorial. The editor, S.A. Clarke, then responded.

"The Democrat has our sympathies. We agree with him heartily, for once. It is evident that some female of the above eloquently described species has attempted to marry our Albany contemporary; but hold out stoutly, brother; don't do it. The community will applaud you, and you shan't be hurt. By the way, what fearful powers of description the Democrat has; but what have Luther and Patrick Henry got to do with it?" 85

The 1870 census provides a surprising revelation. More than three years after the passage of the comprehensive anti-miscegenation law the number of reported mixed race 
couples continued to rise in Oregon. Despite the evidence from Catholic Church records illustrating a sizable decline in the number of interracial marriages and both social custom and legal barriers dissuading potential partners, the trend towards fewer interracial families did not materialize in the census. As in the case of the 1860 census -- which showed an unexpectedly substantial rise in the number of interracial couples from the 1850 census -- recording diligence must have played an instrumental part in the jump. The 1870 census totaled 105 interracial marriages. 86 Hundreds of children were listed as the children of these unions. 87

As in 1860, southern Oregon offered a strong interracial presence. Coos County produced thirteen couples with some form of miscegenation. ${ }^{88}$ Ten of the marriages were between white men and full Indian women. In all ten marriages, the children were listed as one-half Indian. One couple was listed as a white man and a one-half Indian, with their four children listed as one-fourth Indian. Another couple was Henry Barrett, a forty-four-year-old farmer from New York and Mrs. Cora Barrett, a twenty-five-year-old "mix" woman born in Oregon. Three children were listed as "mix," while the youngest, a four-month-old infant, was listed as one-half mix. ${ }^{89}$ The final interracial couple was listed as a white man and a one-half "mix" woman.

The ten husbands married to full Indian women were 67 
farmers and gold miners who hailed from Kentucky, Missouri, Ohio, Pennsylvania, Tennessee and Vermont. 90 There were no French-Canadians as the foreign birthplaces included Denmark, England and Hamburg. All but one of the ten was too young to have married before the migration of the $1840 \mathrm{~s}$ but all of the couples could conceivably have been married before the anti-miscegenation law.

The records of coos county illustrated an interesting development which pervaded the 1870 Oregon census. In hundreds of cases throughout the state, a child whose parents were white and full Indian had their original one-half Indian designation scratched out. A large "W" had been penciled in over the original mark. Several other counties underwent these alterations, including Curry County, where any reference to one-half Indian was scribbled over with a "W." 91 Curry county recorded seven marriages between white men and full Indian women, one marriage between a white man and a one-half Indian woman, and one marriage between a black man and a one-half Indian woman. 92 As in coos County, none of the men were French-Canadians. Douglas County listed fourteen white-Indian marriages but none of the children from these unions were referred to as one-half Indian. The nine marriages between a white man and a full Indian woman with children had the children listed in two ways.93 In five of the families, the children were originally marked as Indian, then someone scribbled over this mark with a "W." In four of these marriages, 68 
all of the children were characterized as white without any prior marks or scratching out.

Two of the Douglas County marriages highlighted the precarious nature of pioneer record keeping. In the census David O'Neal was a twenty-nine-year-old farmer born in Pennsylvania who lived with Rosa, a seventeen-year-old Californian. 94 Two children, a four-year-old and an infant, lived with the couple. In the census David was slated as white while Rosa and the two children were designated as Indian. Yet David and Rosa's Douglas County marriage certificate dated June 17,1870 made no reference to race or ethnicity. 95

Frank Acosta was a thirty-seven-year-old farmer born in Mexico who was living with twenty-five-year-old Cecillia, who was born in Washington Territory. 96 Frank was listed as white, Cecillia as Indian, and four children, ages six to two months, were listed as Indian, as well. In a request for a Douglas County marriage license from an undetermined year in the 1860s "Mary Cecile Dumont" was referred to as a "half breed Indian" who was over the age of eighteen. 97 The justice of the peace who wrote the request for Frank and Mary Cecile noted that he hoped "it would not be nesisary [sic] for them to be sworn." 98

Douglas County revealed the first census evidence of a marriage between an Indian man and a white woman. 99 Peter Grolouis was a forty-three-year-old farmer born in Oregon. Florence was his forty-year-old wife who was born 69 
in British Columbia. 100 Their seven children, ranging in age from ten to one month, were all born in Oregon and all recorded as Indian. There were no scratch outs or additions to their information. The final Douglas County interracial marriage was between an Indian man and a mulatto woman .

The two remaining southern Oregon counties, Jackson and Josephine, continued to provide ample evidence of racial intermarriage. Jackson County listed eleven marriages between white men and Indian women. The 1870 census noted that George Marshall, a thirty-eight-year-old miner from Missouri, shared his residence with five Oregon-born Indian women, including three adults and two children. 101 One of the adults was Celia, a twenty-seven-year-old woman. In August 1871, George and Celia were one of four white-Indian couples married by the same Jackson County justice of the peace.

According to the marriage certificates, Justice James Wade married Frank Silva and "Nancy an Indian woman" on August 2, 1871, at Silva's house. 102 Then Silva's residence hosted the marriage of Edward Langley and "Betsy an Indian woman" on the same day. 103 The certificates were filed and recorded the next day by Jackson County clerk Silas Day. On August 14, 1871, Wade wed Thomas Brown and Sarah Kane "an Indian woman" at Brown's home. 104 Two days later George Marshall and "Cecelia an Indian woman" were married by Wade. 105 Both of these certificates were 70 
duly filed and recorded by the county clerk. Three of the marriages were particularly intriguing because the women lacked last names and were clearly spelled out as Indian women, yet the County clerk did not ask for an affidavit to verify the race of the couples and did not delay recording the marriages.

Jackson County's western neighbor, Josephine County, totaled two interracial marriages, both between white men and Indian women. 106

The eastern portion of the state showed very little census evidence of intermarriage, with Grant county in the southeast registering only one white-Indian marriage, and northeastern Umatilla County listing one white-Indian marriage and one white-mulatto marriage. 107

Splayed across central Oregon, Wasco County illustrated a diverse collection of families, and displayed evidence again of someone tampering with the original information. Wasco recorded five white-full Indian marriages, one white and one-half Indian marriage, and one black-Indian marriage which was celebrated in June $1870 .^{108}$ In the cases of the four white-full Indian couples with children, the children of these unions were listed originally as one-half Indian but someone covered these in thick ink with a "W."109

The northwest corner of the state provided some evidence, with Benton County on the coast listing four white-full Indian marriages and one marriage between a white man and a one-half Indian woman. 110 clackamas county 
recorded two interracial marriages but neither breached the anti-miscegenation law as the couples were a mulatto man and an Indian woman and a black man and an Indian woman. 111 In Clatsop County, the census stated that the county clerk, S. Aiken, was married to an Indian woman. 112 The fifty-two-year-old clerk from England lived with thirty-six-year-old Maria and their three children, ages fourteen to one month. All three of the children were listed as Indian. Clatsop included five other white-Indian marriages, with four of them rewritten so that children with an Indian classification then had a "W" added to the ledger. ${ }^{113}$ The one marriage between a white man and a one-half Indian woman listed the two children as one-quarter .

In Multnomah County, the number of couples may not have been sweeping but they exhibited racial diversity. The couples consisted of a black man and a mulatto woman, a mulatto man and a black woman, a black man and an Indian woman, and two marriages of white men and Indian women. ${ }^{114}$ In an intriguing instance, Mary Lee, a twenty-year-old prostitute from China had a one-year-old son who was born in Oregon. Mary's race was Chinese while the son's was listed as "m." In the child's parental information, the slot for "father of foreign birth" was left blank while under "mother of foreign birth" there was a slash. 115 Marion County dominated the interracial landscape as it had in 1860 . The county brimming with 
French-Canadians and their descendants listed ten marriages between white men and full Indian women, twenty-eight marriages between white men and one-half Indian women, and eighteen marriages where the husband and wife were both one-half Indian. 116 None of the white-full Indian marriages appear to have been performed after the anti-miscegenation statute became law. The records of st. Paul from 1866 to near the turn-of-the-century and St. Louis from 1869 to 1900 fail to document any white-full Indian weddings. However a smattering of marriages were performed between whites and half-Indians as well as with couples who were both one-half Indian. 117

In every case in the Marion County census, people of mixed racial heritage were designated as "HB," or half-breed. More than two hundred children of these families who were originally tabbed as "HB" were written over with a large "W."118 The symbolic power of this erasure of Native American existence could not have been lost on a state where reservations solidified Native American isolation. But the segregation was not as complete as most people believed, and, as four couples in Jackson County showed, marriage laws could not eliminate all attempts at love across the color line. 
1 Bureau of the Census, Eighth Census of the United states, 1860, Oregon, (Manuscript Census Schedules). Another racial examination of the 1860 oregon census is found in K. Keith Richard, "Unwelcome Settlers: Black and Mulatto Oregon Pioneers, Part I," Oregon Historical Quarterly 84 (Spring 1983). In addressing interracial marriages, Richard writes that the "census of 1860 reveals six such unions in which one partner was white and the other black or mulatto, and three in which the female was Indian and the male was black." (p. 42) Richard does not list white-Indian marriages in his total because they lie outside the scope of his work. In all, Richard finds nine interracial marriages in the 1860 census. Excluding the white-Indian couples, I also totaled nine unions. We found the same three black-Indian couples, and the same four white-mulatto couples in Jackson County and one white-mulatto couple in Umpqua County. We uncovered different examples for the sixth marriage. Richard lists a Multnomah County marriage between a black man and a white woman. I discovered a Marion County marriage between a white man and a mulatto woman.

2 Bureau of the Census, Seventh Census of the United States, 1850, Oregon, (Manuscript Census Schedules).

$3 \mathrm{MCS}, 1860$.

4 Ibid.

5 Ibid.

6 Ibid.

7 Ibid.

8 Ibid.

9 Ibid.

10 Ibid.

11 Ibid.

12 Ibid. A seminal study of mulattoes is found in Joel Williamson, New People: Miscegenation and Mulattoes in the United States (New York: The Free Press, 1980). Williamson states that "mulatto' in the United states has generally been understood to refer to people in whom the mixture of black and white is visible. 
Such, for instance, was the use made of the word in the United States Census from 1850 to 1920." (p. xii)

The issue of defining "mulatto" is addressed in Winthrop Jordan, White Over Black: American Attitudes Toward the Negro, 1550-1812 (Chapel Hill: University of North Carolina Press, 1968). Jordan notes that while there was no uniform designation of mulatto, the trend throughout the United States was to link blacks and mulattoes.

"Americans lump together both socially and legally all persons with perceptible admixture of Negro ancestry, thus making social definition without regards to genetic logic." (pp. 167-168)

A study of the definition of mulatto in individual states is found in Thomas Morris, Southern Slavery and the Law, 1619-1860 (Chapel Hill: The University of North Carolina Press, 1996). Virginia's influential definition in 1785 listed a mulatto as a person with one-fourth or more "negro" blood, while North Carolina favored a percentage of one-sixteenth. (p. 23) Morris adds that the definition broadened even further later in the nineteenth century when the "one-drop" rule "apparently existed in the south after the end of slavery." (p. 27)

\section{Ibid.}

14 Ibid.

15 Ibid.

16 Ibid.

17 Ibid.

18 Ibid.

19 Ibid.

20 Ibid.

21 Ibid. The Wasco County marriage index listed four of the white-Indian marriages listed in the 1860 census as occurring in 1856, 1858, and two in 1859.

22 Ibid.

23 Ibid. 
24 McLagan, p. 64 .

25 MCS, 1860 .

26 Codes and Laws of Oregon, 1862 , p. 660 .

27 The Oregon Statesman, 18 December 1865, p. 1 .

28 Chronological List of Oregon's Legislatures, p. 78 .

29 Portland Oregonian, 17 September 1866.

30 Ibid.

31 Ibid.

32 Oregon. Journal of the Fourth Regular Session of the House of Representatives, 24 September 1866.

33 Portland Oregonian, 6 October 1866, p. 2 .

34 Ibid.

35 Ibid.

36 Ibid.

37 Ibid.

38 Ibid.

39 Ibid.

40 Ibid.

41 Ibid.

42 Ibid.

43 Ibid.

44 Ibid.

45 Ibid. The divisive 1866 legislature illustrated a political pattern in Oregon history where the differing parties wrangled over political issues but shared similar racial views. This may help to explain why oregon Republicans such as starkweather held a view much more bigoted view than the national Republican leadership. David Alan Johnson shows that a decade earlier the Republican and Democratic politicians who met at the state's Constitutional Convention of 1857 showed a "unanimity on matters of race" at the otherwise 
contentious event in Founding the Far West:

California, Oregon and Nevada, 1840-1890 (Berkeley:

University of California Press, 1992), p. 181 .

The Oregon political climate in 1866 is discussed in

Walter Carleton Woodward, The Rise and Early History

of Political parties in Oregon, 1843-1868 (Portland:

J.K. Gill Company, 1913). Woodward notes that the Oregon

Democrats hoped to make black equality a major issue

in the upcoming elections. In response, the Union Party,

filled with Republican supporters, created a party

platform both vague and moderately conciliatory to

Democratic leanings. (pp. 244-248)

46 Ibid.

47 Ibid.

48 Ibid.

49 Ibid.

50 Ibid.

51 Ibid.

52 Ibid.

53 Ibid.

54 Ibid.

55 Journal of the Fourth Regular Session, 4 October 1866 . A Representative McCoy moved for an amendment to shift Kanakas from the Indian percentage of more-than-one-half to the one-quarter or more percentage of blacks and Chinese. The amendment was passed by an unspecified vote. The amendment was not included in the Oregonian's roundup of the debate. Interestingly, the House Journal referred to Mr. McCoy, yet a reference book on legislators does not list a McCoy serving in the 1866 session.

56 Oregon. Journal of the Fourth Regular Session of the Senate, 13 October 1866 .

57 Ibid., 15 October 1866

58 Oregon Laws, 1866, p. 10

59 Ibid.

60 The text of the anti-miscegenation law appeared in several state newspapers, including the oregonian and 
the State Journal, as well as others.

61 The Oregon Statesman, 8 October 1866, p. 2 .

62 Ibid.

63 Ibid.

64 Ibid.

65 Albany State Rights Democrat, 13 October 1866, p. 2 .

66 Ibid.

67 Ibid.

68 Ibid.

69 Ibid., 3 November 1866, p. 2 .

70 Ibid.

71 Ibid.

72 Ibid.

73 Ibid.

74 Portland Oregonian, 12 september 1867, p. 2 .

75 Ibid.

76 Ibid.

77 Ibid.

78 State Rights Democrat, 28 september 1867, p. 1 .

79 Ibid.

80 Ibid.

81 Ibid.

82 Ibid., p. 2 .

83 Ibid.

84 Ibid.

85 Salem Daily Record, 30 September 1867, p. 2 .

86 Bureau of the Census, $\frac{\text { Ninth Census of the United States, }}{78}$ 
1870, Oregon, (Manuscript Census Schedules).

87 Ibid.

88 Ibid.

89 Ibid.

90 Ibid.

91 The specific reason for the removal of all references to "half-breeds" in the 1870 Oregon census remains unclear, but the Oregon revision may have been related to a nation-wide undercount of racial minorities. Nationally, the 1870 census "suffered from extremely poor field procedures and some badly worded questions. It was plagued with undercounts, local demands for recounts, and inadequate responses to questions," as shown in Margo Anderson, The American Census: A Social History (New Haven: Yale University Press, 1988), p. 78 .

The subject of quantifying the Indian population posed a dilemma for the Bureau of the Census. The history of Indians in the federal census is shown in Hyman Alterman, Counting People: The Census in History (New York: Harcourt, Brace and World, 1969). Alterman states that "until 1860 there was no reference to the Indian in any census. The few who were counted were probably included among the 'free colored." (p. 293) This was the case with Oregon's federal census in 1850 where more than three dozen references to Indians of some degree were listed in the "white and free colored section." In the three subsequent federal censuses, Alterman shows major fluctuations in the number of "Indians taxed" in the 1860,1870 and 1880 census. This category listed Indians who lived among the white population. The census for these years excluded Indians living on reservations or under the supervision of Indian agents. The national total for 1860 was 44,021 , but dipped in 1870 to 25,731 and then jumped in 1880 to 66,407 . (p. 293) "One does not have to be an expert to sense that these numbers do not describe real people. From 1860 to 1870 , the population is almost cut in half. In the next ten years, it increases more than oneand-one-half times," writes Alterman. "Since 'Indians taxed' lived among the white population, they were less subject to violent changes in number. Therefore, the changes are the result of different techniques and emphasis rather than being real changes in the number of 'Indians taxed." (p. 293) The removal of references to half-breed and mixed racial ancestry also occurred in at least one Southern state, South 
Carolina. The federal census finally recorded all Indians for the first time in 1890 .

The instructions to census enumerators in 1870 spelled out the directions in filling out the color category, especially in regard to blacks. "Be particularly careful in reporting the class Mulatto. The word is here generic, and includes quadroons, octoroons, and all other persons having any perceptible trace of African blood," the instructions stated. (p. 275) In the first census after the Civil War, blacks also faced an undercount. Alterman adds that the census "totals, especially for Negroes, were too low and were revised in later years by the Bureau of the Census." ( $p$. 275)

Locally, K. Keith Richard extensively studied the 1870 oregon census for his work in "Unwelcome Settlers: Black and Mulatto Oregon Pioneers, Part II" Oregon Historical Quarterly 84 (Summer 1983). Richard makes no mention of the scratching out.

92 Ibid.

93 Ibid.

94 Ibid.

95 Douglas County, Oregon. O'Neil marriage certificate, 17 June 1870 .

96 MCS, 1870.

97 Douglas County, Oregon. Acosta marriage license, date indecipherable, circa 1860s.

98 Ibid.

99 MCS, 1870 .

100 Ibid.

101 Ibid.

102 Jackson County, Oregon. Silva marriage certificate, 2 August 1871 .

103 Ibid., Langley marriage certificate, 2 August 1871.

104 Ibid., Brown marriage certificate, 14 August 1871.

105 Ibid., Marshall marriage certificate, 16 August 1871 . In the 1880 Jackson County census Thomas Brown was a fifty-eight-year-old gold miner listed as white. 
Sarah Brown, who was fifty-years-of-age, was described as Indian and Thomas's "wife." The Langley's also were included in the 1880 Jackson County census, with Edward, a forty-five-year-old gold miner, listed as white while Betsy, his thirty-four-year-old "wife," was described as Indian. The 1870 census for Jackson County listed Justice of the Peace James Wade as a thirty-nine-year old accountant from Tennessee married to a white woman from ohio.

106 MCS, 1870.

107 Ibid.

108 Ibid.

109 Ibid.

110 Ibid.

111 Ibid.

112 Ibid.

113 Ibid.

114 Ibid.

115 Ibid.

116 Ibid.

117 Harriet Duncan Munnick, Catholic Church Records of the Pacific Northwest, st. Louis, vol. 3, and st. Paul,

118 MCS, 1870 
RESERVATIONS WITH MARRIAGE:

RACIAL INTERMARRIAGE IN THE OREGON INDIAN CENSUS

FROM THE 1880s TO THE $1930 \mathrm{~s}$

During the mass immigration of the 1840s, swarms of settlers arrived in Oregon deeply covetous of the Indian lands. As Oregon evolved from provisional to territorial status, the acquisition of Indian areas became a paramount issue. When the Oregon Territory was formed in 1848, a federal superintendency of Indian affairs began to administer the region's Indian issues. Joseph Lane, the first territorial governor, served as the ex officio Indian superintendent until a separate official was appointed in 1851. 1 The Donation Land Act propelled the white encroachment onto these historic homelands. Congressional action formalized a federal policy to transfer the Indians and sped up the desire to extinguish Indian titles to land. "An 1850 federal law put forth the first Indian policy in Oregon by providing for a separate superintendent of Indian affairs and a treaty commission." 2 Federal and local authorities devised plans to extricate Indians from their lands in western Oregon and transplant the Indian populations to less desirable Eastern Oregon. While Indian tribes were amenable to treaties, they would not move East. "Originally, the Western Oregon tribes were to move east 
of the Cascade Mountains, but it was [Superintendent Joel] Palmer's decision to move them to a location on the coast, with the coast Range being the barrier to the valley," writes William Eugene Kent. ${ }^{3}$

Tensions escalated in the 1850s, with armed conflicts erupting in the Rogue River Wars in southern Oregon. Treaties obtained by superintendents Anson Dart and Palmer with the western and northern Indians reduced white hostilities by the end of the decade. In the following decade, the more isolated Indians of south-central and eastern Oregon agreed to treaties. Fearful of prolonging white takeover without any compensation, many Indian tribes adopted a pragmatic stance in the face of this alarming cultural disruption and dislocation.

By the end of the 1860 s, four reservations served as the new homes for many of the State's Indians. The Klamath Reservation was perched on the California border in south-central Oregon. The Siletz and Grand Ronde reservations ran along oregon's central Pacific coast. The Umatilla Reservation was nestled in the northeastern pocket of the state and the Warm Springs Reservation was located in central oregon. According to the authors of Oregon Indians, "the treaties brought about the most dramatic changes in Oregon Indian life between 1851 and $1868 . " 4$

The wrenching partitioning of the Indians was accomplished at the same time that the Bureau of Indian 83 
Affairs implemented a paradoxical plan. "While authorities used the separatist method of isolating tribes in remote areas, supposedly free from lawless frontier influences, they actively encouraged Indians to adopt non-Indian ways." 5 Three jurisdictions -- federal, state and tribal -intermingled in reservation society in a complicated relationship characterized by legally inconsistent interpretations and complicated by fluid boundaries. 6 The United States Constitution empowered the federal government with predominant authority over Indian territories and areas which were commonly referred to as "Indian country." A string of United States Supreme Court decisions since the inception of the reservation system supported the federal supremacy. In a seminal case, United States V. Kagama, the United States Supreme Court upheld the principle that the "Indian tribes are the wards of the nation" whose dependence on the federal government justified Indian submission to federal legal control. 7

Despite the federal government's prominent role in Indian judicial affairs, tribal authority governed a significant portion of internal tribal concerns and issues. In another line of decisions during the nineteenth century, the Supreme court granted tribes a far greater level of autonomy than the paternalistic legal approach. In an 1883 case which summed up this delegation of power, the Court in Ex Parte Crow Dog ${ }^{8}$ said that federal courts did not have jurisdiction over the murder of one Indian by 84 
another in Indian country.

According to the authors of The Nations Within: The Past and Future of American Indian Sovereignty, "there is no inherent power in any of the fifty states to deal with Indians at all." 9 Yet even though federal and tribal legal powers tended to supersede states' authority, state law increasingly encroached on Indian affairs in the reservation period, especially where white and Indian communities lived in close proximity. "The rights of the states within Indian country are based ultimately on the presence of non-Indian citizens within Indian country," writes Charles Wilkinson in American Indians, Time, and the Law. "As non-Indians moved in, so too did state law."10 When Indians did not live on the reservation or land controlled by the Bureau of Indian Affairs, state power was the foremost legal authority in their lives. "Not all Indian lived on trust land, and those that did not were generally subject to state laws in the same manner as any other citizen," notes Theodore Taylor in The Bureau of Indian Affairs. ${ }^{11}$ Location played a vital role in determining whether an Indian fell under state jurisdiction. According to Felix S. Cohen's Handbook of Federal Indian Law, state courts "usually have jurisdiction over Indians where the cause of action or some material event occurs outside Indian country."12

In the 1880s, several Oregon legal cases hinged on the conflict between these competing legal interests and 
highlighted the ascension of state law in the lives of Oregon Indians. "Three parallel cases developed in Oregon at the same time in a concerted [Bureau of Indian Affairs] effort to give Oregon criminal jurisdiction over reservation Indians," writes Sidney Harring in Crow Dog's case, an examination of nineteenth century Indian law. 13 In July 1880, the Bureau of Indian Affairs asked the army to detain three Siletz Indians on murder charges until the state assumed jurisdiction. After more than two years of languishing at Fort Vancouver without trial, the trio of Siletz Indians were released after the local Indian agent refused to comply with orders to hand them to state authorities. $^{14}$ In March 1883, a Grand Ronde Indian was convicted in state court and sentenced to death for the murder of two Indians on the reservation. 15 A third case involved a Siletz Indian arrested for murder and detained in the Benton County jail in Corvallis. Siletz agent E.A. Swan was directed by Washington superiors to first request that state officials appoint an attorney for the Indian. If state officials refused the request, then Swan was to ask the United States Attorney in Portland to select legal counsel. "The BIA requested an opinion from the [United States] attorney general, who acknowledging that Congress had failed to take jurisdiction over such crimes, held that Oregon had criminal jurisdiction over reservation Indians because such jurisdiction was not specifically excepted upon Oregon's admission to the union."16 
In 1887 the General Allotment Act, better known as the Dawes Act, accelerated the pace of non-Indian incursion into Indian country and the growing white presence helped to blur the jurisdictional lines in Oregon. The Act allowed reservations to be divided into individual allotments, which could not be sold for twenty-five years. Indians in Oregon were forced to choose an allotment on reservation land or have an allotment chosen for them. In either case, citizenship was conferred on an Indian who received an allotment. Ostensibly, the Dawes Act intended to acquaint the reservation Indians with private land ownership and farm practices. Instead, the act became a device that non-Indians used to accumulate valuable land. Furthermore, land which was left over after the allotment period was surplus land available on the open market. Many Indians in Oregon sold or rented their allotments to whites.

Just after the turn of the century, Commissioner of Indian Affairs W.A. Jones sent a directive which spelled out the Indian Affairs' marriage policy to all officials in charge of Indian agencies. The directive clearly bestowed upon states the power to define the type of marriages Indians could enter and placed the Indian officials in a subordinate position to the specific racial stipulations which existed in legislation such as Oregon's law. 17 Under the 1901 rules, United States Indian Agents were authorized to issue marriage licenses to Indians who wished to marry. The Indians could be married by a 
clergyman, a civil officer, or they could express vows of monogamy before witnesses. The memo stated "that no Indian shall be permitted to marry a person of any other race except in the manner prescribed by the laws of the state or territory in which such Indian resides."18

The Oregon Supreme Court affirmed Oregon's right to regulate interracial marriage in In Re Estate of Fred Paquet, a 1921 case which marked the only time the state's highest court tackled the 1866 marriage ban while the law existed. 19 The court was asked to determine who should receive the estate of Fred Paquet, a white man who died in Tillamook County in September 1919. Ophelia Paquet was a full Clatsop Indian who held that she was Fred's widow due to a marriage by Indian custom some thirty years before in the county. 20 The couple never attempted to marry through the state. John Paquet, Fred's brother, claimed that he was the rightly heir to the estate. Due to conflicting decisions by the circuit court, both parties appealed to the supreme court.

Even though the couple did not attempt to marry through state offices, Ophelia contended that the 1866 marriage law was unconstitutional and a discriminatory barrier, yet the Supreme court held that the law applied an equitable standard. "It will be noted that the statute does not discriminate. It applies alike to all persons either white, negroes, Chinese, Kanaka or Indians," the opinion stated. 21 The court ruled that an Oregon marriage between a 
white person and an Indian of more than one-half blood was valid only "where Indians lived together under the tribal relation and a tribal form of government and for the reason that they would then be subject only to the jurisdiction of Congress." 22 The Paquets did not fit this standard.

"She was not living on a reservation and was not a ward of the United States government, in fact the alleged marriage took place within Tillamook County and at a place where the state would have original and exclusive jurisdiction over any marriage contract between them, and both parties then lived and mingled with the white people as ordinary citizens of the state. Neither the government nor any Indian tribe had any control or jurisdiction over the place of the alleged marriage... As in this case where both parties and the alleged marriage were within the original and exclusive jurisdiction of the state, they are subject to and are bound by the state law." 23

Ultimately, the Court ruled against Ophelia on the major points of her appeal. The judges ruled that she was not legally the wife of Fred. They found her claims of custom marriage dubious. And they upheld the constitutionality of the interracial marriage law. Yet despite the overwhelming defeat of her legal right to the estate, the Court still expressed sympathy for her plight. "Although the question is not before this court, the writer feels that in the interests of justice, a fair and reasonable settlement should be made," the court said. 24

Beginning in the mid-1880s before the passage of the Dawes Act and running for more than a decade after the Paquet decision into the late 1930s, the microfilm 
collection of the annual Indian censuses provides half a century of evidence of interracial marriage in oregon. 25 The Indian agents who ran the Oregon reservations kept population figures from the inception of the reservations. Following the passage of the Dawes Act, the census of Indians became a crucial tool in determining Indian status and allotment eligibility. References to marriages with non-Indians grace the records of the four geographically distinct and autonomously administered reservations. By the late 1910s, specific Indian blood percentages were included next to each individual. In the $1920 \mathrm{~s}$ birth records stated the race of the parents. By the 1930s, the censuses combined each of these racial components with the inclusion of non-Indian spouses to show unequivocally that Indians and whites did not live separate lives. While the records do not verify an instance of an Indian agent contravening the 1901 Bureau of Indian Affairs policy by marrying a white person and an Indian of more than one-half blood, a succession of agents over more than fifty years knew that county clerks and clergymen solemnized a bounty of marriages which contravened the state marriage law. The Indian census illustrates that more than sixty years after the imposition of the reservation system and the initiation of the marriage ban Indians and non-Indians of many races across the state married and raised families with the full knowledge of local and reservation officials. 


\section{The Klamath Census}

Bordered by the lofty Cascades and demanding waterways, the Klamaths were sheltered from white contact longer than most of the region's Indians. The Hudson's Bay Company forged preliminary links with Southern oregon in the late 1830s, with several of the Company's employees marrying Indian women. The relative isolation and cordial relations were vanquished by the expeditions of J.C. Fremont, who chastised the region's Indians for their "treacherous disposition."26 The menacing tone of Fremont's expeditions in 1843 and 1846 was replicated by the pioneers who followed in his wake. "The American settlers, far from seeking a complementary role, were the first active competitors with the Indians for lands and resources," writes Theodore stern. "They brought with them wives who were often appalled at the Indian way of life, and they established for themselves an insular world in which the Indian could find little place." 27

Amidst the unfriendly overtures from the settlers and ominous fate of several severely displaced tribes, the Indians of the Klamath region signed a treaty on October 14, 1864.28 Twenty-one Klamath chiefs and four Modoc chiefs agreed to give up the lands east of the Cascades for the confines of the Klamath Reservation, located to the east of Crater Lake. 29 The Klamath Agency was instituted in May 1866 a few miles south of Fort Klamath. Due to intertribal rivalries, the Modocs were situated at Yainax, 
a sub-agency established in 1870 thirty-five miles east of the main boundary. ${ }^{30}$ The reservation was proclaimed officially open in February 1870.31 A military road was proposed which would pass straight through the reservation and during the 1870 s homesteaders began to settle along the road's right-of-way. 32

Interracial marriages and relationships were prevalent and well documented. In 1869 , an Indian agent based in Jacksonville to the west of the reservation reported sixty Indian women living in "casual unions" with whites, together with their children. 33 Many whites frowned upon interracial unions, especially when the relationships were seen as casual. "Indignant settlers in the Klamath Valley circulated a petition in 1870 , demanding that whites living with Indian women and fathering children upon them be required to marry them or that the women be sent back and punished by law," writes Stern. 34

"As time went on, however, a small but growing number of stable marriages appeared in the areas fringing the reservation; and others, contracted about the same period, later came to light in more distant regions in the course of allotting tribal members," writes Stern, who added that few mixed couples tried to remain on the reservation. 35

"The official and lay attitude was disdainful of 'squaw men,' and they in turn must have been reluctant to subject themselves to the minute regulation of Agency life and the limited economic opportunities there . . They may have found the kinsmen of their wives both abundant and demanding . . The wives may have been eager to reach6 beyond the limited opportunities of the reservation." 
In one case, a white man and his Indian wife who lived on the reservation made a special request during a family medical emergency. In January 1879, Klamath Agency agent Sinus Nickerson asked permission from the Commissioner of Indian Affairs for an Indian woman to bring her sick family members off the reservation. "Tobey Riddle, a Modoc woman, the wife of Frank Riddle, a white man living, desires to have father 'aged and infirm man' and Charley Riddle 'who is nearly blind' reside with her off the reservation," wrote Nickerson. "They need constant care and she is willing and anxious to care for them. I should have said that Charley Riddle is her brother. I would recommend that the request be granted for four months from February $1,1880 . " 37$

The Klamath Agency census of Indians begins on microfilm in 1885 , with reservation officials keeping records of the Indians by the categories of Indian name, English name, relationship in the household, sex and age. In 1895, the first reference to interracial marriages appeared in the census record. Compiled by U.S. Agent Marshall Petet, the 1895 document was also the first to list Indians alphabetically by their English name. Emma Coburn, a twenty-nine-year-old Klamath woman was the "wife of Joseph Coburn, white man." 38 The Coburns had four children, with their ages ranging from seven to two. Another twenty-nine-year-old Klamath woman, Belle White 
Miller, was recorded as "married [to] Jas H. Miller, white man."39 Neither of the husbands were listed in the census. The 1895 document included an interracial reference as the seven-year-old child of Louisa Johnson, a thirty-eightyear-old wife, was designated as "1/2 breed."40 The 1896 census listed Coburn and Miller as married to white men. In 1897, U.S. Indian Agent Joseph Emery separated the census into two sections, with Klamaths listed first and Modocs and Paiutes in the second section. Several new interracial relationships appeared. In the Klamath section, Belle Miller was listed as the wife of a white man. Lucinda Siemens was married to a white man, however her three sons, aged nine to three, did not receive a one-half designation. 41 The Klamath portion included Andrew Jackson, a fifty-three-year-old man described as a "negro adopted."42 Jackson was married to Susie Jackson, a forty-eight-year-old woman who was also known as "so-toke." 43

The Modoc and Paiute section included two references to interracial marriage. Ollie Davis was a thirty-two-year-old woman married to a white man. 44 This section also included a reference to tribal adoption for the Riddles, who were the subject of Nickerson's 1879 letter. Frank Riddle, a sixty-five-year-old "white man adopted" was married to Toby Riddle, a fifty-four-year-old woman also known as "Wi-ne-ma. 45

In both 1898 and 1899 , the annual census prepared 94 
by O.C. Applegate, the U.S. Indian Agent, failed to include any interracial references other than the two adopted tribal members. In 1898 only Andrew Jackson was included as a "negro adopted" while in 1899 both Jackson and Riddle were listed with references to their races. 46

In 1900 Applegate reinstated the references to interracial marriages. Eight Indian women were listed as the wives of white men, while the Jackson marriage was the only reference to a black-Indian union. Besides Coburn, Riddle and Siemens, five Indian women -- Lizzie Knight, Annie Lenz, Lavina Mann, Lydia Sampson, and Daisy Williams -- between the ages of nineteen and thirty-seven raised a total of twenty children with their husbands. 47

The 1900 federal census for Klamath County provided a similar view of racial intermarriage. Eleven interracial marriages were listed in the federal census, with seven of these marriages also documented in the Indian census. 48 All seven were recorded in the section for the "Klamath Indian Reservation."49 The reservation portion of the federal census included a category which documented the percentage of white blood. Coburn and Mann were described as the one-half Indian wives of white men who were ranchers. Thirty-six-year-old Emma and fifty-one-year-old Joe Coburn had been married for fourteen years. 50 The Manns, twenty-six-year-old Lavina and thirty-four-year-old Larry, had been married for twelve years. 51 Knight and Lenz were listed as one-half Indian wives of white men who were 
farmers. Thirty-one-year-old Annie had been married for fourteen years to thirty-nine-year-old German immigrant Charles Lenz. 52 Lizzie Knight was twenty-years-old while her husband William was twenty-seven-years-old. 53 They had been married for four years. Williams, who was an eighteen-year-old Klamath with one-half Klamath blood, had been married for just a year to Marvin Williams, a thirty-five-year-old white man employed as a stockman. 54

Five marriages with full Indian women were listed in the Klamath County census. The Jackson's thirty-year union was recorded with the couple living on the reservation. Andrew was a fifty-five-year-old black farmer from California while susie was a full Klamath born in Oregon. 55

Two marriages were recorded between white men and full Indian women who lived off the reservation as residents of Klamath Falls. Both of these couples were not listed in the Indian census. Antoine Prairie, a native of Portugal who had lived in the United States since 1882 , had been married to Amele, an Oregon-born Indian, for seventeen years. 56 The Prairies, who were both forty-one-years-old, had a fourteen-year-old son, who was listed as an Indian. 57 Thomas Moore was a sixty-five-year-old white man married to Mary, a fifty-five-year-old Indian. 58 Five children between the ages of twenty seven and seven were listed as Indian. 59 Two white-full Indian couples who lived on the 96 
reservation were included in the Klamath County census. The Riddles had been married for forty-two years. Sixty-five-year-old Frank was referred to as a "white man adopted into Modoc" and fifty-five-year-old Toby listed as a full Modoc. 60

A curious oversight to the Indian census during this time was that the yearly figures never showed that Julia Shaw was married to a white man when several sources, including the 1900 Klamath County census, proved that she and her husband forged a long-term relationship. A Lake County marriage certificate noted that James Shaw and "Julia (Indian)" were married by a minister of the gospel on May 13, 1881 at Shaw's house. 61 The request for a marriage license showed that two witnesses appeared before Justice of the Peace William Wright on April 26, 1881. In a sworn statement, Thomas Laing said that he knew James Shaw and "Julia (Indian)" personally and knew they had lived in Lake County for more than six months preceding the application and that each was over the age of twenty-one. 62 The thirty-year-old Shaw's sworn statement said that he wanted to enter into marriage with "Julia (Indian)" and that neither he nor the twenty-eight-year-old Julia were married presently. ${ }^{63}$ There was no mention of the law which banned marriage between whites and Indians of more than one-half blood and apparently the justice of the peace approved the request.

Julia Shaw was first mentioned in the Klamath Agency 97 
census in 1890 as a fifty-year-old wife. However in 1895, when the first references to marriages to white men appeared in the Indian census, Julia was not mentioned as having a white husband. In the 1900 Indian census Julia Shore [sic] is a sixty-one-yearold mother of two children, James, aged seventeen, and Ellen, aged fourteen. 64 There is no mention of being married to a white man.

Yet in the 1900 federal census for the Klamath Indian Reservation, James Shaw is the white fifty-eight-year-old head of a household with Julia, his fifty-two-year-old "wife," listed as an Indian. 65 The federal census noted that the couple had been married nineteen years. James was born in England while Julia was born in Oregon to parents both born in Oregon. They shared their residence with Lizzie Duvall, a twenty-two-year-old Indian stepdaughter and their children, James and Ellen, both listed as Indian. 66 In a section of the federal census on tribal affiliation, James, Sr. was listed as white, Julia was listed as Klamath with both her parents Klamaths, and the three children were Klamaths with a white father and a Klamath mother. 67 In the section on white blood percentage, Julia received a zero while the children were listed as one-half. ${ }^{68}$ By the 1910 federal census for Klamath County, Julia was a seventy-year-old Indian widow with a son listed as Indian but with a blood entry listing him as one-half Indian and one-half white. 69

In the 1901 Indian census conducted for the Klamath 98 
Agency, six of the women found in the 1900 Indian census were listed again as being married to white men, with the Jacksons marked as the sole black-Indian union. Thirty-two-year-old Esther Silvers Hart was included in the census as the wife of a white man and the mother of an eight-year-old daughter. 70

The census for 1902 listed twelve interracial marriages, with eleven Indian women married to white men and one black-Indian couple. Besides Coburn, Hart, Lenz, Mann, Siemens, and Williams, the record included a number of new entries. The new brides to the census included Laura (Ball) Witt, a twenty-seven-year-old Indian woman who had a one-year-old daughter known simply as "baby."71 Mollie Marcelle, an eighteen-year-old woman, was married to a white man but lived at the residence of her Indian mother, Minnie Corbell. 72 Another bride, Maggie Jane Pearson, who was twenty-six and the mother of a six-month-old daughter, also lived with her mother, Kate Cole. 73 Twenty-one-year-old Mary Parazoo lived with her seven-year-old son and her sixty-seven-year-old aunt. 74 The final addition in the 1902 census was Celia Brown Dufault, the forty-two-year-old mother of four children, ages ten to one. 75

In 1903 the total dipped to eight interracial marriages, with the only addition being Josie (Ball) Dompier, a forty-seven-year-old woman. 76 The 1904 and 1905 census did not provide any new marriages. In 1906, 
two new entries indicated mixed marriages. In a section listing Indians who lived off the reservation, Nellie Smith, a twenty-year-old was married to a white man. 77 The same year not only was Mollie Marcelle listed as married to a white man but her mother, Minnie Corbell, also was listed as the wife of a white man. 78

After a dozen years of records which listed at least one interracial marriage, the census stopped all references to mixed race relationships and families. Beginning in 1907 with Superintendent Horace Wilson, the censuses for the next twelve years under four other superintendents made no reference to whites or interracial marriages. 79

During this era, the reservation brimmed with allotment controversies which hinged on determining who was to be admitted as a tribal member. The Bureau of Indian Affairs used the term "enrolled" to describe formal membership in a specific tribe. The non-enrolled fell into two camps, either non-Indians or Indians who were listed in a spouse's Indian census but who were members of another tribe.

The original allotments were made in 1895 and resumed in 1909. But all children born after April 15, 1910 would be excluded from a share of land even though they were tribal members. If a person was born before April 15, 1910 then tribal membership was determined by the tribal council and, at times, the Indian agent. In this enrollment process, they used two criteria -- tribal kinship and residence with the tribe -- to make the final decisions 100 
on membership. 80

Federal legislation passed in this period further eroded the geographic lines between Indian and non-Indian cultures. Furthermore, the Burke Act of 1906 increased the number of whites with property on the reservation. The Burke Act left the trust period at twenty-five years but gave the Office of Indian Affairs authority to give selected Indian allottees patents which exempted their land from "all restrictions as to the sale, incumbrance or taxation." 81 Once the patent was obtained, citizenship was conferred on the allottee who was free to manage the land as they wished. By 1917, according to the History of Klamath County, "all [Indians] of less than half Indian blood and a number of others judged competent by a commission acting at the Agency had received patents." 82 While the census may not have shown any interracial marriages, the Agency still was interested because the information aided in preparing the annuity roll, which outlined who received the annuity payments from allotment trusts. $^{83}$ W.B. Freer, the chief clerk in charge of the Klamath Agency, asked the Klamath County clerk in January 1916 for "a list of all marriages between Indians of this reservation and between whites and Indians of this reservation which show on your records from January 1 , 1915, to January 1, 1916."84 He asked the county clerk "if we could be informed of any Indian marriages immediately after they have been entered in your office." 85 
Following a dozen years with no hint of a white presence or an interracial marriage in the annual censuses, the Indian census of 1919 appears quite remarkable for the depth of racial characterization. The 1919 census, the inaugural census for Supervisor in Charge Walter West, was the first census to include an entry on the degree of Indian blood. While there were no references to white husbands, the degree of blood of the mother and the children meant that the amount of Indian blood of the fathers could be calculated. The 1919 census included twenty cases where the mother was listed as full Indian or "4/4" and the children were listed as one-half Indian, thereby indicating that the husbands and fathers were non-Indians. 86 From the earlier censuses, two women, Minnie Corbell and Nettie Smith, fell into this category. In the cases of James Brown and Boyd Jackson, they were full Indian fathers with children listed as one-half. In five instances -including Emma Coburn, Celia Dufault, Annie Hart, Lucinda Siemens and Laura witt -- the mother was one-half and the children were one-quarter. 87 In two cases, including Annie Lenz, the mother was one-quarter Indian and the children were listed as one-eighth. 88

In 1920 West recorded fifteen cases where the mother was a full Indian and the children were one-half. 89 The same two full Indian fathers were listed with children of one-half blood. The census also recorded three Indian women who were listed as one-half and their children were 102 
listed as one-quarter.

Under the guidance of West, the 1921 census not only determined Indian blood percentages but added references to marriages with white men. Eleven women were married to white men. Five of the women were full Indian, with two of the wives listed as one-half and four listed as one-quarter. 90 Fanny Alta Gallagher Captain was a full Indian women born in 1892 who had two pre-teen daughters with the last name Gallagher. 91 Both of the girls were listed as one-half Indian blood. A third daughter, Lola, was born on June 10, 1921 and listed as one-half Indian blood. Amanda Hazel Conney Sargent Wilson, whose name reflected a number of marriages, was a full Indian woman born in 1893 who was married to a white man.92 Wilson's first child was a son with the last name Conney who was listed as a full Indian. But her second child, a daughter born on March 27, 1921, had the last name Sargent and was listed as one-half. An additional seven women were full Indians with children of one-half blood but no reference was made to a white husband.

The 1921 census did uncover an irregularity in which Minnie Corbell was recorded as one-half Indian but in the 1919 census she was listed as a full Indian. Her husband, John Corbell, was a white man enrolled as an Indian with documents from 1920 to verify this enrollment. 93 Despite Minnie's change of status, the Indian census rarely swayed in its blood percentages for an individual and displayed 103 
a yearly consistency.

Yet, once again, the census did go through patches when the racial information became scarce. The census for the rest of the 1920 s produced a wavering record. The few references to blood percentages for most of the decade would not unearth marriages where the Indian spouse was more than one-half Indian and therefore in violation of the marriage law. The census of 1922 through 1925 did not make any reference to marriages with white men. The only reference to interracial marriage in the 1926 record was Irving Crawford, a one-half Indian born in 1898, who was married to a white woman named Wilda Smith. ${ }^{94}$ one daughter born on January 21, 1926 was described as one-quarter. In the census the following year, the crawford marriage was the only one mentioned as interracial. 95

In late 1926 a local white rancher and prospective groom called on Superintendent L.D. Arnold to help him find a bride. The letter was filled with references which indicated that his quest to form a white-Indian union was not uncommon in the area. Jerome Fellers asked Arnold if the Klamath official could relieve him of his isolation on a La Pine ranch.

\footnotetext{
"As I am living on one of the meadow ranches of a cow outfit near here, and being it my permanent cow-coup and a working place, I've decided to get someone, who would make a good clean housekeeper, good common cook, and I know, there always were few girls of good, clean record, on the reservation, that were anxious to become a white man's wife. As to my calling and living in this pretty, 
but remote places, I am sure, I gguld not, keep a white woman on a ranch like this one."

Fellers described himself as a fit

thirty-three-year-old who enjoyed horseback riding and hoped to find a woman who liked the outdoors. "I have no objection against Klamath blood, whether quarter, half, or full. I will greatly appreciate your kindness of letting me know of how to get about, in this very problem," wrote Fellers. 97 Superintendent Arnold responded with a curt reply. "Please be advised that I am unable to give you any information in regard to any Indian girl who I believe would be interested in your proposition." 98

Yet while the Indian census during the middle and late 1920s made fewer references to interracial unions, the Klamath Agency began collecting birth records which served as evidence of miscegenation. Beginning in 1924, the annual census added a section listing the births to parents enrolled at the jurisdiction. Along with the child's tribe and degree of blood, the birth entries included specific references to the degree of blood of the parents. Between July 1924 and December 1936, the Klamath Agency recorded 482 births, with only six of the children born outside Oregon. In eighty-six of the births, or eighteen percent, the child had a white parent. In the case of thirty-eight children, or eight percent, the infant had a white parent and an Indian parent of more than one-half blood. Of the forty-nine births recorded 
between July 1, 1924 and June 30, 1925, eleven children had a white parent. 99 Nine fathers were white, with four of these men becoming a parent with a woman of more than one-half Indian blood. Two white women had a child with a father who was one-quarter Indian.

Seven of the fifty-one children born between July 1, 1925 and June 30,1926 had a white parent. 100 Eleven of the fifty-eight children born between July 1, 1926 and June 30,1927 had a white parent. ${ }^{101}$ Five of the forty-two children born between July 1, 1927 and June 30, 1928 had a white parent. 102 In the listings for July 1, 1928 to June 30,1929 -- which showed eight of thirty-eight children with a non-Indian parent -- the first reference was made in the birth record to a race other than white. 103

"Unnamed" Lotches was born on January 13, 1929 to a Mexican father and a full Indian woman. 104

In the 1929 general census, directions from the office of Indian Affairs spelled out the blood specifications for each Indian. If the person was full blood then the agent should mark the person with an "F." If the person possessed mixed blood then an "M" was to be used.105 However, Superintendent Arnold overlooked this order. Instead, he broke the degree of blood into percentages, with "4/4" signifying full Indian blood. Only two women were listed as full Indian blood with children listed as one-half. 106

The census did not include references to marriages 106 
with non-Indians, but a page from the Klamath census titled "marriages included in 1929 annual statistical report" listed two categories. 107 There were eleven marriages "between Indians" and eight listed "between Indians and whites."108 The lists did not show blood percentages but by using Indian census information from the 1930s, it becomes clear that several of the couples defied the marriage ban with an Indian spouse possessing illegal blood percentages. In the case of one 1929 couple, Abraham Charlie was a Klamath-Wasco Indian in his early sixties listed as a full blood married to Mildred Hobart, who was classified as a white woman. 109 vincent Bodner was a white man who was married in 1929 to Alfarata Skeen, who was a three-quarter Modoc in her early twenties. 110 The next year the office of Indian Affairs sent new instructions for charting blood percentages. Each person in the 1930 census would receive one of three marks. A full blood Indian would receive an "F." An Indian with one-fourth or more Indian blood would receive a "1/4 +." For less than one-fourth Indian blood, a person would be designated as "- 1/4."111 In 1930, unlike 1929, Arnold obeyed the directions. The 1930 census provided very little information on interracial marriage. The records failed to state which Klamath Reservation Indians were married to people of another race. However a list of the twenty-one marriages in 1930 involving Klamath Agency Indians possessed significant evidence of interracial marriage. The list 107 
showed ten marriages between Indians and recorded eleven marriages "between Indians \& Whites," with four of the marriages matching couples who crossed the legal limits. 112 Odis Wagner was a white man married to Imogene Moore, a full Klamath-Modoc in her early twenties. 113 Eldon Cress was a white man who wed Dina stokes, a nineteen-year-old full Klamath. 114

Adding to the lack of information which could be gleaned from the 1930 census was the ambiguity of a listing which stated "1/4+." Both Helen Applegate and her daughter Mabel Hendricks received "1/4 +" distinctions, yet an observer cannot presume to estimate the race of the father because of the number of degrees which fall under the category of one-quarter and above. 115

But even though the census record was less than complete the casual observer on the reservation could see that interracial links were prevalent. "In 1930, at a time when the total enrollment of the tribe was some 1,250 persons, the predominantly non-Indian population of one such reservation town, Chiloquin, and its environs was roughly 1,850 , a figure which placed it second in size in the entire county," writes stern. "Indian-white relationships in such communities could no longer be adequately regulated by the Agent."116

Following his census of 1931, which used the vague percentages of plus and minus, Agent C.M. Blair returned to the specific blood percentages in 1932. While references 
to marriages with whites were not included in the census, for the first time in the Indian census, non-enrolled people were entered. ${ }^{117}$ All of the non-enrolled people in the 1932 census were husbands of Indian women. However, these non-enrolled husbands did not have any racial information or data in the slots for age, tribe or degree of blood. The Bodners were listed in the 1932 census. Vincent Bodner was married to Alfarata Skeen Bodner, who was a twenty-five-year-old Modoc who possessed three-quarters Indian blood. Their child, Vincent Jr., who was born in March 1929, was listed as three-eighths Indian. ${ }^{118}$ The 1932 census also included seventeen non-enrolled husbands who lived with wives with the following blood percentages: five were married to women of three-quarters blood; one was married to a woman with five-eighths blood; six were married to women of one-half blood and five were wed to women of one-quarter blood. ${ }^{119}$ In all cases, the children of these couples had a blood percentage which could be calculated only if the father possessed no Indian blood.

The 1933 census of the Klamath Reservation proves unequivocally that racial intermarriage thrived. Conducted by Field Agent B.G. Courtwright, the census was the first to record the race of the non-Indian spouses. Combined with the specific blood percentages of the Indian spouse, the 1933 census brimmed with evidence that racial intermarriage was commonplace in twentieth-century Indian life. In total, ninety-six marriages joined a non-Indian 109 
with an Indian. 120 The census revealed thirty-two marriages which violated the state marriage law, which banned marriages between whites and Indians of more than one-half Indian blood. ${ }^{121}$ The census revealed nine marriages between white men and full Indian women, seven marriages between Mexican men and full Indian women, and two marriages between white women and full Indian men. ${ }^{122}$ Eleven marriages were between white men and women of three-quarter Indian blood. In one instance, Alfred Lara, a Spanish man, was married to Gertie Duvall, a Klamath of three-quarter Indian blood. ${ }^{123}$ The Lara and Duvall marriage had been the only one listed as between an Indian and a white in the 1932 statistical report on marriage. 124 Another marriage brought together a white woman and an Indian man of three-quarter blood. The census also included a marriage between a white man and a woman of five-eighths Indian blood.

Even though a good number of interracial marriages did not run afoul of the law's percentages, they highlighted the prevalence of uniting Indian and non-Indian cultures. Twenty-two marriages were between white men and one-half Indian women. Two marriages were between white men and three-eighths Indian women. Twenty marriages were between white men and one-quarter Indian women, and a further five were between white men and one-eighth Indian women. 125 The interracial patterns of Indian men became more visible in the 1933 census. Four marriages joined white women with one-half Indian men. Seven marriages were 
between white women and one-quarter Indian men and four marriages wed white women to one-eighth Indian men. 126

In a Klamath Agency memo listing marriages between the spring of 1933 and 1934, three categories of marriage showed fourteen legal marriages between Indians, one marriage by Indian custom, and five marriages between Indians and whites. 127 one of the interracial marriages was illegal. Gilbert Banford, a white man, married Grace Kane, a thirty-seven-year-old full Klamath. They were one of nine new interracial couples who graced the 1934 census. 128 Three of these marriages were illegal. Administered by Wade Crawford, the 1934 census resembled the 1933 census by including the race of non-Indian spouses and the specific blood percentages of Indians. The vast majority of the 1933 interracial couples were included in the 1934 census and the blood percentages for the Indians were the same as the previous year.

The census skips to 1937 , the last year that is available on microfilm. Crawford again listed race and blood percentage. But the census also included marriage data for newlyweds directly in the census and not just in a separate portion as previous years. The 1937 document contained twenty-two interracial couples which had not been listed before in the census. 129 Four of these marriages were between white men and women of more than one-half blood. Seventy-two interracial marriages which had appeared in previous census produced a total of 
ninety-four marriages. Troy Baldwin, a white man, adopted three full Indian stepchildren when he married Rebecca Charlie, a thirty-four-year-old full Klamath-Wasco. 130 The couple together had two children, ages two years and two months, who were listed as one-half. Imogene Moore Wagner, a twenty-nine-year-old full Klamath-Modoc, was married in 1935 to Floyd Fisher, a white man. 131 Mildred Lotches was a nineteen-year-old three-quarter Klamath-Shoshone who married Milburn Riddle, a white man, on May 27, 1935. 132 The Klamath Falls couple lived with their infant daughter Arlene, a three-eighths Klamath-Shoshone, who was born on June $5,1935.133$ Elvada Anderson, a twenty-year-old who was seven-eights Klamath-Modoc, was married to William Truran. Dewey, their one-year-old son, was listed as seven-sixteenths.

\section{The Siletz Census}

Located on Oregon's central Pacific coast, the Siletz Reservation was forged from a violent tempest. The Rogue River Wars in southern Oregon erupted in the first half of the 1850s. Frenzied gold miners and land hungry farmers increasingly encroached on historic Indian lands in the Umpqua region. The settlers viewed the native people with a particularly harsh disdain. The merest of perceived Indian transgressions produced vigilante volunteers scouring the region. 134 Indian reprisals set off a corresponding round of white attacks. In the summer of 1856 , Superintendent of Indian Affairs Joel Palmer ended the 
last vestiges of Indian resistance and carried out the terms of the signed treaties. Hundreds of Southern Oregon Indians from a plethora of tribes with distinct linguistic groups were transported in 1856 to the Siletz Reservation, originally called the Coast Reservation. 135 Two hundred more who were rounded up by the military walked the 125 miles north to the reservation bracketed by the Coast Range and the Pacific Ocean. 136 willamette Valley tribes resided on the much smaller Grand Ronde Reservation, which was built on the eastern side of the range after officials found that transporting supplies across the mountains was expensive and arduous. 137

Life at the Siletz Reservation for the varied conglomeration of Indians was problematic. Farming proved difficult in the mountainous environment. In 1865, a twenty-five mile swath running through the center of the reservation was diverted to whites so they could enjoy the economic opportunities on the coast in Newport. This cut the reservation into two sections. 138

The trend by the $1880 \mathrm{~s}$ saw a reservation continually swallowed up by land cessions, aided especially by the Dawes Act. Controversy hounded the handling of the final allotment decisions made in the 1890s. Land that had been ceded from the reservation by a proclamation from President Grover Cleveland was opened up for public sale in 1895.139 Between 1865 to 1910 , the original siletz area of some $1,3000,000$ acres and the Grand Ronde area of 60,000 acres 113 
shrunk by three-quarters. ${ }^{140}$ By the turn of the century, the population of the Siletz and Grand Ronde Indians came into greater contact with whites and dipped to less than 500 from the original 2,500.141 "After several generations of inter-tribal marriage at siletz, the distinct

characteristics of the different people disappeared," writes Kent. "Like his typical Caucasian counterpart, the siletz Indian is a product of several racial stocks. Many siletz people also married non-Indians as well."142

The Siletz census history, which begins on microfilm in 1896, did not immediately portray an interracial population. Providing the sketchiest view of interracial relations among the four reservations, the Siletz Agency census made its first reference to marriages with white men in 1911. Twenty-fiveyear-old Flora Chapman was the "wife of Lewis Chapman, white man."143 Agnes Newberry "married Mr. John Isaakson, white man" and Inez Larsen was listed as the wife of a white man. 144

In 1913, three more Indian women were listed as married to non-Indians, including Esther Pond and Nellie Aasen. Sixty-five-year-old Anna Orton was "married for some years to Rocky Detello, an Italian."145

The birth record for the Siletz Reservation was kept intermittently. Between 1919 and the spring of 1933 the census accumulated sixteen births and eight of these involved a white parent. However, after 1933, the siletz documents referred to interracial children with increasing 114 
regularity. From the spring of 1933 to the end of 1936, sixty-six births were recorded with twenty-two, or just over a third, including a white parent.

The census record failed to detail interracial marriages or children for almost two decades. But just as the birth records beginning in 1933 showed a more pronounced interracial quality to siletz life, the census carried out by James Ryan in 1933 recorded an interracial presence. While the directions for the census called for people to be listed in one of three ways -- F, 1/4+, and $-1 / 4$-- Ryan used specific blood percentages and listed spouses of Indians by their race. 146

The 1933 Siletz census unearthed fifteen interracial marriages, of which eleven skirted the marriage law. 147 Seven of the marriages involved white men and Indian women of more than one-half blood. George Baker was a white man married to Evaline Baker, a forty-five-year-old full Rogue River Indian. ${ }^{148}$ The Bakers had seven one-half Indian children ranging in age from twenty to four. Merrick Darcy was married to twenty-nineyear-old Maggie Dais, a full Kusa. 149 David Shrum was married to Lena Norwest Riggs, a forty-one-year-old full Umpqua. 150 verma strong was a twenty-two-year-old Tututni who was listed as fifteen-sixteenths Indian blood. She was married to Andrew Jay Goodell and together they had a two-year-old daughter who was listed as fifteen thirty-seconds. 151 Three couples were comprised of white men married to three-quarters 
Klamath women in their early fifties. The seven children from these marriages were all listed as three-eighths. 152 The only Mexican-Indian marriage joined Jesus Castonon and Jane Baxter, a seventy-one-year-old Tillamook. 153

The census also included four marriages between white women and Indian men which overstepped the racial percentages of the state law. 154 The Logan brothers, thirty-one-year-old Abeson and twenty-four-year-old Augustine, were full Tututni married to white women. 155 The five children from their marriages were all listed as one-half. In addition, twenty-three-year-old Lawrence Klamath, a seven-eighths Klamath Indian, was married to Kathleen Weller, a white woman. 156 Herman Hudson was a twenty-nine-year-old Umpqua listed as three-quarters Indian. 157 He was married to Ella Taplin and together they had a son listed as three-eighths.

In the 1934 census conducted by Ryan, ten of the 1933 couples were listed, but even though the Indian entries included blood percentages, the census failed to record the race of any of the non-Indian spouses. 158 However, a separate section carried out at the Salem Indian School revealed six interracial marriages with references to the half-dozen white husbands included in the entries. 159 All six of the wives listed at the boarding school were Fourth Section Allottees, a group of non-reservation Indians who were allotted some 5,000 acres of land in southewestern Oregon during the 1890 s under the fourth section of the 116 
Dawes Act. 160 None of these marriages involved an Indian woman of more than one-half blood.

The 1937 census carried out by Superintendent Paul Jackson discovered fourteen instances of interracial marriage in three categories. 161 The census of the siletz Reservation of the Salem Indian School documented one marriage between a white man and a full Indian woman. The Bakers, who were listed in the 1933 census, had six children who were all listed as one-half Indian. ${ }^{162}$ The other interracial couple in this section were the Koehlers, a white man and a one-half Chastacosta woman. Their five-month-old son, Richard, was listed as one-quarter Chastacosta both in the Indian census and the birth records of 1936.163

There was a single interracial marriage in the census of the Grand Ronde Reservation of the Salem Indian School, with Andrew Riggs, a fifty-seven-year-old full Umpqua married to Amanda Riggs. They had nine children, who were all listed as one-half. 164

The section on Fourth Section Allottees of the Salem Indian School contained eleven interracial marriages, with two of these exceeding the legal blood percentage. 165 Clyde Estabrook was a white man married to Helen Estabrook, a twenty-four-year-old Umpqua with a blood percentage of seventeen thirty-seconds. 166 Abraham Fry was a twenty-eight-year-old Rogue River Indian of three-quarter blood who was married to a white woman named Lorraine. ${ }^{167}$ 117 
Earl, their one-year-old son, was designated as three-eighths and was listed in the 1935 birth records. 168 The remaining interracial marriages fell into the following categories: five marriages between white men and one-half Indian women; two between white men and three-eighths Indian women and two between white men and one-quarter Indian women. 169

\section{The Umatilla Census}

The Umatilla, Cayuse and Walla Walla tribes reluctantly moved to the northeastern pocket of the state to their designated reservation which lay in the direct path of the Oregon Trail. 170 created by the Walla Walla Treaty of 1855, the Umatilla Reservation, from its inception in 1860, was not an isolated refuge or free from strenuous white interference. Lush grasslands which produced enviable grains enticed white settlers. ${ }^{171}$ The burgeoning town of Pendleton grew on the western cusp of the reservation. "In 1882 the tribes sold 640 acres to the town of Pendleton, but the biggest diminution of the tribal land base came three years later when Congress passed the slater Act."172 The legislation ordered the reduction and allotment of the Umatilla Reservation. The original treaty area of some 250,000 acres was lopped to approximately 160,000 by $1888 \cdot 173$

The microfilm of the Umatilla Agency census begins in 1886 with a clear understanding of the interracial dynamic on the reservation. B. Coffey, the Umatilla Indian 118 
Agent, wrote to the Office of Indian Affairs in July 1866 stating that in accordance with office instructions sent earlier in the year he was providing a census of "Indians and mixed bloods residing on the reservation."174 The census counted three tribes, with a total of 723 Umatilla, Cayuse and Walla Walla Indians. The 1886 census separated the additional 171 mixed bloods into their own section. 175 Ten mixed blood women living on the reservation were listed as married to white men. ${ }^{176}$ While several women were old enough to marry before the marriage statute became law, four of the wives were too young to marry before 1866 . Two sets of Indian children, the four Depot children, ages twenty to twelve, and the six Gignon children, ages twenty one to eleven, were listed as living with their white father. 177

The 1887 census deviated from the prior census by placing the mixed breeds within their tribal affiliation. So, one mixed Umatilla woman was listed as married to a white man and the six members of the Depot family were listed as mixed. 178 There were no references to mixed breeds among the 407 Cayuse. Yet, of 406 Walla Wallas, 205 were listed as mixed blood. 179

When Coffey sent his 1888 census to Washington in July, he added that he separated the three tribes and placed the mixed bloods in each tribe. 180 Once again, the Walla Walla produced the greatest number of mixed blood references, with 199 included in the total of $406 .^{181}$ 
The Umatilla recorded twelve mixed bloods out of 171 Indians and the Cayuse did not have a single mixed blood reference in the total of 407 .

A succession of Indian Agents from 1889 to 1905 included references to mixed bloods. 182 But since the 1887 document, the census did not make any references to marriages with whites. During this time, the white presence grew on the reservation. The first allotments and land sales commenced. Sales began in April 1891 and allotments were issued until December 1892. ${ }^{183}$ Valuable timber and grazing lands evaporated. "Frequently, when trust periods expired, they were forced to sell or lease their lands to non-Indian farmers and ranchers."184

A history of Umatilia County written at the turn of the century described the racial makeup of the reservation by discussing the demographics of the full blood and mixed blood populations.

"It is a rather remarkable fact that all the Indians on the reservation are full bloods, except the 200 Walla Wallas. There are 400 Cayuses, 200 Umatillas, 200 Walla Wallas, and 200 Walla Walla mixed bloods. These Walla Walla mixed bloods are the descendants of marriages between Hudson's Bay Company employees and Indian women who lived near the old post at Wallaula. The Indians are not dying off in this country, for in forty years the population of the reservation has not varied 100 souls. There are not so many $\mathrm{fH}_{\mathrm{f}} \mathrm{l}$ bloods, but the numbers have not diminished."

In 1910, the Indian census resumed after a four-year absence. The new superintendent, E.L. Swartzlander, complained to the Office of Indian Affairs that census data was incomplete. Furthermore, he believed that approval 120 
decisions on applicants for tribal funds were being made with erroneous numbers. "The division of tribal moneys was based on a population of 1205 Indians, though from what records the office obtained this number I cannot say," Swartzlander wrote in August 1910. "If the office wishes to approve any more of the applications in the office of Indians for their shares of the tribal funds, I recommend that the matter be held in abeyance for at least six months longer. At that time I will have a complete census of the Indians of the Umatilla Reservation."186

Four months later, Swartzlander sent his superiors an updated census. "The Indians belonging to this reservation are scattered over the entire northwestern part of the United States, and by corresponding with them I have been able to complete the census," wrote Swartzlander. 187 However the census of December 1910 , with 1065 total Indians, and the subsequent censuses from 1911 to 1913 made no reference to mixed blood or marriages with whites.

In August 1914 Swartzlander sent his recently completed survey to the office of Indians Affairs accompanied by a letter explaining the difficulties in gathering an exact count. "The census has been made with a great deal of care, and it is believed it is as near correct as it is possible to make it considering the scattered condition of the mixed blood allottees of the Umatilla Reservation," he wrote. "So far as the full blood Indians are concerned 121 
the census is absolutely correct."188 Yet, while the letter made such a strong distinction between mixed and full blood Indians, the 1914 census did not contain any references to mixed blood Indians, let alone to interracial marriages. 189

Over the next fourteen years, three superintendents kept an annual census but none of these documents made references to mixed bloods, marriages with whites, or blood percentages. In 1920, Swartzlander's census included a cover page stating that there were 584 full blood Indians on the census rolls and 533 mixed blood Indians. ${ }^{190}$ But the individual entries did not include information on mixed blood status.

Yet it was during this barren period for interracial references that the Umatilla Agency began collecting birth information. Beginning in July 1924 and running through December 1936, the Umatilla Agency recorded 259 births, with twenty-four babies, or nine percent, born to a white parent. A mere two of the twenty-four children were born to a white parent and an Indian of more than one-half blood. The first four years of the recording showed that only six of the eighty-three children had a white parent. In a further two instances, the listing showed a child born to a white mother and a father of $1 / 4+"$ Indian blood and a child born to a white father and a mother of $1 / 4+. "$ Even when individual blood percentages were added to the birth statistics in 1931, the interracial evidence from 122 
birth records was scant.

In 1929, O.L. Babcock, who had overseen the annual census since 1925, mentioned blood percentages for the first time in the body of the Umatilla census. Babcock placed specific blood percentages in the census even though it ran counter to Indian Affairs instructions. The instructions sent with the 1929 census stated that if an Indian was a full blood then an "F" should be used and if they were mixed blood then the recorder should use an "m."191 While the names and race of the spouses of the enrolled Indians were excluded in 1929, the blood percentages of the Indian parent and the children illustrated interracial relationships. Maud Barr was a full Indian born in 1903 who was listed as a wife. 192 She had a one-year-old son, John, who was listed as one-half. Under these percentages, the father was a non-Indian. The census also included four couples with a husband who was one-quarter Indian and a wife who was a full Indian. 193 There was one instance of a one-half Indian woman and her one-quarter child. Additionally, eighteen Indian women and nine Indian men were classified as one-quarter with children listed as one-eighth. 194 Two women were listed as one-eighth and their children were designated as one-sixteenth. On a separate page, Babcock provided an in-depth summary of the two racial categories which totaled 489 full bloods and the 619 mixed blood Indians. Each of these 123 
groups was broken into age groups. There were six children under one-year of age who were mixed blood. ${ }^{195}$ Twenty-five children between the ages of one and three were mixed blood while fifty-eight children between the ages of four to nine were mixed blood. For the ages ten to nineteen, there were 112 mixed bloods, and 137 mixed bloods between the ages of twenty and twenty nine. More than eighty-five percent of the mixed blood population of the Umatilla Reservation was under fifty years of age. 196

In 1930 and 1931 Babcock reverted to using the categories which cannot be studied to determine specific interracial relationships. He followed instructions and referred to full blood Indians as "F" and used "1/4+" for Indians of one-fourth blood or more and "-1/4" for Indians with less than one-fourth blood.

However the 1932 census contained a massive body of evidence verifying interracial marriage. Non-enrolled husbands were added to the census by their race and specific blood percentages were used. The census recorded 130 interracial marriages. 197 All of these marriages were between an Indian woman and a nonIndian man. Four marriages were between a white man and an Indian woman of more than one-half blood. Roy Hart was married to Lucy Laton, a forty-one-year-old full Cayuse-Umatilla. ${ }^{198}$ Their sixteen-year-old son was listed as one-half. Another local marriage paired Edward Todd with Lillian, a twenty-three-year-old Cayuse-Nez Perce. ${ }^{199}$ Two of the 
couples lived in Portland. Mary Walton was a forty-three-year-old full Walla Walla married to James Walton. 200 The other Portland residents were Josephine Warren, a thirty-year-old Umatilla-Walla Walla listed as eleven-sixteenths Indian, who was the wife of Roy Warren. 201 Roy adopted a stepson, Orville Perry, a six-year-old listed as nineteen thirty-seconds Indian. 202

The 1932 census highlighted the expanding demographics of the Indian populations, with many of the couples living outside of Oregon. Fifty-eight marriages matched a white man and a one-quarter Indian woman. 203 Twenty-one of these couples lived out of state. There were forty-four couples comprised of a white man and a one-eighth Indian woman. 204 Twenty of these couples resided outside Oregon. The percentages were divided into even smaller increments, as seven marriages were between white men and one-sixteenth Indian women and two marriages were between white men and Indian women of one thirty-second blood. 205

Three Mexican-Indian couples appeared in the census. Margaret Lara was a local full blooded Indian with Cayuse, Nez Perce and Umatilla heritage. The twenty-three-year-old Margaret was married to a Mr. Lara whose first name was not recorded. 206 The two other marriages were out-of-state couples consisting of a Mexican man and a one-half Indian woman.

While not against the law, the four black-Indian marriages added examples of the interracial diversity of 125 
Indian life. Bill Bell was a "Negro" married to Alice Barnhart, a forty-year-old full Umatilla woman. 207 Two full Indian stepchildren, ages fifteen and twelve, lived with the Bells. The three remaining couples lived in Portland. These marriages were between a black man and a three-quarter Indian woman, and two marriages between a black man and an Indian woman of five-eighths blood. 208 The census compiled by Babcock in 1933 was quite similar to the prior year's document as it included specific blood references and the race of the non-Indian spouse. The major difference was the inclusion of interracial couples where the husband was Indian and the wife was white. None of these twenty-eight couples had a husband who was more than one-half Indian. 209 Sixteen of the couples lived in state. The 1933 census added nine new marriages between white men and Indian women. 210 But none of these broke the marriage ban. In total, there were 161 interracial marriages Iisted in the 1933 census. 211

The 1934 census listed 160 marriages between whites and Indians of one-half or less blood. Only two marriages -- the Waltons and the Warrens of Portland -- breached the specifications of the marriage law.212 After an absence of two years, the census returned in 1937 with Babcock recording 165 interracial couples in the last census on microfilm. 213 The Waltons and Warrens once again served as the only evidence of couples who flouted the marriage ban. 214 


\section{The Warm Springs Census}

The varied Indians of the Columbia River who formed the Confederated Tribes of the Warm Springs Reservation faced similar obstacles to fostering traditional practices and keeping historic lands. White encroachment and government encouragement escalated in the 1850 s and by 1855 these tribes agreed to sign a treaty with Joel Palmer. The tribes swapped ten million acres for just under half-a-million in the face of government promises of payments and fishing and hunting privileges. 215 The coterie of Indian tribes faced a difficult cultural adjustment. From a rich history of fishing on the Columbia River, the Warm Springs tribes were thrust into an agrarian lifestyle in the desolate areas of central oregon, which represented the southern tip of their original territory. According to the authors of Oregon Indians, "subsistence farming combined with livestock and traditional food gathering enabled the people to survive the many leans years until timber production became a significant tribal resource in [the twentieth] century."216 The daunting adjustment was compounded in the early 1860 s by raids conducted by Northern Paiutes and, in the decades to follow, boundary disputes with government officials and local residents. 217 The first available Warm Springs census in 1886 shows that United States Indian Agent Jason Wheeler tracked a number of distinct tribes. 218 Along with Warm springs Indians, Wheeler kept separate numbers for John Day, Paiute, 
Tenino and Wasco Indians. From 1886 to 1913 , eight superintendents or Indian agents kept census records which did not make any references to mixed blood Indians, blood percentages or marriages with non-Indians.

In 1914, Superintendent Gilbert Hall furnished the first mention of a non-Indian in the census. Born in 1891, Adeline Brunoe was the wife of a Filipino referred to by only his last name, Auguilar. 219 Andrew Gabhart was the white husband of Bessie Peat, who was born in 1888. Three pre-teen stepdaughters lived at the Gabhart residence. 220 The next year, in a census conducted by A.M. Reynolds, the new superintendent, the only non-Indian reference was to Brunoe's Filipino husband, Estanslau Aguilar. 221 In the 1916 census compiled by Reynolds both Aguilar and Gabhart were included in the list of names but neither had a reference to their race. 222 Gabhart did not appear in the census record following 1917 while Aguilar appeared in each census until 1921 but with no mention of his nationality.

In 1922 Superintendent O.L. Babcock, who first administered the Warm Springs census in 1919 and later served at the Umatilla Reservation, collected several intriguing racial components in the census. Estanslau Aguilar was referred to as a "Philapeno" [sic] while Adeline was termed a Wasco. 223 The Aguilars had two daughters born in 1917 and 1920. Characterized as a "Jap,"224 George Danzuka was the husband of Loraine Brunoe, a Wasco who 
was born in 1898. The Danzukas had three sons, born in 1918, 1920 and 1921. Tom Robinson was the "Negro" husband of Annie Smoke, a Paiute born in 1882. 225 The final interracial marriage was between Manuel Garcia, a Mexican born in 1889, and Jeanette Brunoe, a Wasco born in 1894.226 In addition to two stepchildren, the couple raised Alfonso Garcia, a son born September 25, 1921.

From 1923 to 1927 , these four men were the only non-Indians stated as husbands of Indian women. In the case of Aguilar, in the 1926 census, he was listed with two daughters but no wife. 227 The next year Aguilar appeared in the census married to Evaline Polk, a Tenino born in 1908 and listed as Aguilar's "2nd. w."228

During this period, the Warm Springs officials started to collect birth data. From July 1924 to December 1935, the Agency recorded 288 births, with ten of the children, or just over three percent, having a non-Indian parent. The majority of these children were born to three of the interracial families previously described in the census. George Aguilar was born on February 22, 1930 and had his tribal affiliation listed as Wasco and Tenino. 229 Under degree of Indian blood, Aguilar's father was listed as none and his mother as full. The births of three Danzuka children were listed in the records. Ruth Danzuka was born on February 9, 1926, Virgil Danzuka was born on December 14, 1927, and Jerry Danzuka was born on March 29, 1930. 230 Virgil and Jerry were listed as Wasco while 129 
Ruth was listed as Warm Springs. Yet all of them shared a father with no Indian blood and a mother who was full Indian. The Garcias had three children in the birth records. Lupie, who was listed as Wasco, was born on November $19,1929.231$ The two other Garcia kids were listed as Wasco and Mexican. They were an unnamed child born on January 12, 1932 and Adolfo born on July 3,1933.232 The three remaining children were all named Kalani. They were Klamath and Wasco children whose father had no Indian blood and whose mother was a full Indian. 233 However, the Kalanis never appeared in the annual Indian census. In 1928, Superintendent J.B. Mortsolf added the first references to blood percentages to the body of the census. Evaline, Aguilar's second wife, was classified as a full Tenino. Aguilar's two daughters from his previous marriage to Adeline were listed as one-half Indian. 234

Loreen Danzuka was listed as a full Warm Springs Indian. The couple now had five children, ranging in age from ten to less than a year old, who were listed as one-half Indian. 235 Jeanette Garcia was a full Wasco and the Garcia's two children, born in 1921 and 1925, were listed as one-half. 236 Tom Robinson's wife Annie, a full Paiute, now lived in an asylum in Canton, South Dakota. 237 F.E. Perkins broke his 1929 census summary into mixed blood and full blood sections. Of the total agency population of 1,004 , roughly twelve percent, or 125 , were placed in the mixed blood slot. 238 In these categories, 
there was a further breakdown by age. Two mixed blood Indians were under a year old. Fifteen were between one and three-years-of-age and a further twenty-five were between the ages of four and nine. 239 In total, ninety-three of the 125 mixed blood Indians, or seventy-five percent, were under the age of thirty. 240

In the body of the census, Perkins included a new classification for interracial children. The description of the Aguilar's two daughters under degree of blood was "m."241 The same was true for the Danzuka's and Garcia's children.

A single white-Indian marriage was included in the 1929 census. Bessie Brunoe Reed, a full Indian born in 1888, was recently widowed by the death of Charles Reed. 242 She lived in Portland. The census also showed a marriage between George Reed, a white man, and Amy Pete, an Indian born in 1908 and listed as "m" under degree of blood. 243 In 1930 the census reverted to a system of defining Indians by one of three categories, with "F" meaning full blood, and "1/4+" and "-1/4" for all other distinctions. This technique had been adopted by several of the reservations in the late 1920s and early 1930s. Yet the 1930 Warm Springs census was unique in the entire catalogue of population surveys because it was the only census where references to a race other than Indian were scratched out after first being clearly recorded. In the case of the Aguilar, Danzuka, Garcia and Robinson families, the wives 131 
and children were included but the husbands were not entered. The Aguilar's two daughters originally had the words "Wasco and Philipino" [sic] typewritten as their tribal designation. But the word Philipino [sic] was marked through with a pen. 244 In the entry for Loreen Danzuka, the typewritten notation that she was the "wife of Geo Danzuka" was scratched out. 245 Under the five children's tribal affiliation, the original typewritten answer was "Wasco \& Jap."246 But the Japanese reference was marked through. The three Garcia children also had the Mexican reference in their "Wasco \& Mexican" affiliation scratched out. 247

Two new entries also faced racial revision. Charles Jackson was a thirty-seven-year-old Indian noted as "Wasco and white." 248 Three children, his father and his brother were also listed as "Wasco and White."249 All six had the white reference lined out. Peter Kalama was a seventy-one-year-old Indian described under tribe as "Paiute \& Hawawiian." [sic $]^{250}$ The reference to Hawaiian was scratched out.

In the 1931 census, the Aguilar, Danzuka and Garcia families were listed without the husbands, but the references to the children's mixed race were not scratched out. The Jackson's mixed race background also escaped revision. The only other reference to non-Indians was in the family of Emma Andrews, a forty-five-year-old Wasco with three illegitimate children. Fifteen-year-old Frank 
Brunoe was a Wasco, seven-year-old Rosie Gilly was listed as Wasco and Mexican, and four-year-old Sally Andrews was Wasco and Yakima. 251

In 1932 , the census reinstated the non-Indian fathers and specific blood percentages. The names were presented but the race of Danzuka, Garcia and Robinson were left blank. The Danzukas six children were listed as one-half Indian of Wasco and Japanese heritage. The Garcias five children were listed as one-half Wasco and Mexican. A new person was added to the Garcia household. Priscilla Hayashi was the eighteen-year-old stepdaughter of Garcia who was one-half Indian of Wasco and Japanese background. 252 As Jeanette Brunoe Garcia was a full Wasco Indian, the inference is that she had Priscilla with a Japanese man in approximately 1914. In the 1933 and 1934 census, the only reference to race was the mixed heritage of Danzuka and Garcia's children.

The 1937 census was the final census collected in the microfilm and included Danzuka's seven children as Wasco and Japanese. Garcia was listed as Mexican and his seven children as Wasco and Mexican. 253 There were two new interracial references in the 1937 census. Elizabeth Luella was a thirty-eight-year-old woman of Wasco and Puyallup ancestry listed as one-half. 254 she and her white husband, Francis Lewis, lived in Portland with two children, ages seventeen and thirteen, who were noted as one-quarter Indian. 255 Jeanette Garcia's daughter of Wasco and Japanese 133 
descent, Priscilla Hayashi, was married to Daniel Macy. Their son, Daniel Herbert, was born on January 8, 1936, and was listed as one-quarter Wasco. 256

The final references in the microfilm mentioned that two of the thirty births in 1938 were interracial. The Danzukas added to their brood when Dewey was born on March 7, 1938. 257 On June 10, the Macy's welcomed Robert Wayne, who was listed as "Wasco-Jap-White." 258

Plainly, by the 1930s, racial intermarriage was entrenched in the communities within and near the Indian reservations. By the 1930s, several of the reservations illustrated a frequency of miscegenation resembling the French-Canadian era a century earlier. Hundreds of interracial marriages and the countless hundreds of children from these unions testified to the reality that Indians were far from isolated from non-Indian cultures. Additionally, dozens of interracial marriages violated the marriage law. The census material from the four distinct areas of the state formed a body of evidence that clearly showed that miscegenation was active in a wide cross section of the population, from urban and rural communities to younger and older generations. The racial intermarriage which the census documented well into the twentieth century mocked the precepts and aspirations of the nineteenth century reservation system and the spirit and letter of the marriage law. 
1 Jeff Zucker, Kay Hummel and Bob Hogfoss, Oregon Indians (Portland: Western Imprints, 1983), p. 71.

2 Ibid., p. 89

3 William Eugene Kent, "The Siletz Indian Reservation 1855-1900" (Masters thesis, Portland State University, $1973), \mathrm{p} .2$.

4 Zucker, p. 89.

5 Ibid., p. 73 .

6 Laurence Schmeckebier, The Office of Indian Affairs: Its History, Activities and Organization (Baltimore: The Johns Hopkins Press, 1927), p. 256 .

7 Charles Wilkinson, American Indians, Time and the Law: Native Societies in a Modern Constitutional Democracy (New Haven: Yale University Press, 1987), p. 24.

8 Sidney Harring, Crow Dog's Case: American Indian sovereignty, tribal law, and United States law in the nineteenth century (Cambridge: Cambridge University Press, 1994), P. 1 .

9 Vine Deloria, Jr. and Clifford Lytle, The Nations within: The Past and Future of American Indian Sovereignty (New York: Pantheon Books, 1984), p. 262.

10 Wilkinson, p. 89.

11 Theodore Taylor, The Bureau of Indian Affairs (Boulder: Westview Press, 1984), p. 19.

12 Felix Cohen, Felix Cohen's Handbook of Federal Indian Law, (Charlottesville, Virginia: The Michie Company, $1982), \mathrm{p} .350$.

13 Harring, p. 117 .

14 Ibid.

15 Ibid.

16 Ibid., p. 118

17 Office of Indian Affairs instructions, 5 April 1901, from Commissioner W.A. Jones to United States Indian Agents . 
18 Ibid.

19 In Re Estate of Fred Paquet, 101 Or. 393 (1921).

20 Ibid.

21 Ibid., p. 399.

22 Ibid., p. 401

23 Ibid.

24 Ibid., p. 402 .

25 The survey of Oregon Indian censuses does not include the short-lived Malheur Reservation, which lasted only from 1872 to 1878 .

26 Theodore Stern, "The Klamath Indians and the Treaty of 1864," Oregon Historical Quarterly LVII No. 3, (September 1956), p. 234.

27 Ibid, p. 237 .

28 Robert H. Ruby and John A. Brown, A Guide to the Indian Tribes of the Pacific Northwest, (Norman: University of Oklahoma Press, 1986), p. 91.

29 Ibid.

30 Ibid.

31 Ibid.

32 zucker, p. 109.

33 Theodore Stern, The Klamath Tribe: A People and Their Reservation, (Seattle: University of Washington Press, 1965), p. 97 .

34 Ibid.

35 Ibid.

36 Ibid. However while Stern notes that official and lay attitudes did not look kindly on interracial couples, he adds on the same page that "interracial unions were encouraged not only by a dearth of white women but by an early preponderance of women among the Klamath and by regulation which put an end to polygamy." (p.98.)

37 Sinus Nickerson, letter of 3 January 1879 , to E.A. 136 
Wright.

38 U.S. Department of Interior, Office of Indian Affairs, Klamath Agency Census, 1895. A set of Agency records show that a series of Indian Agents and ministers performed marriages regularly from the mid-1890s to 1908. While several men and women with white-Indian parents married full blood Indians, none of the couples breached the state's marriage law.

39 Ibid.

40 Ibid.

41 U.S. Department of Interior, Office of Indian Affairs, Klamath Agency Census, 1897.

42 Ibid.

43 Ibid.

44 Ibid.

45 Ibid.

46 U.S. Department of Interior, Office of Indian Affairs, Klamath Agency Census, 1898.

47 U.S. Department of Interior, Office of Indian Affairs, Klamath Agency Census, 1900.

48 Bureau of the Census, Twelfth Census of the United States, 1900, Oregon, (Manuscript Census Schedules).

49 Ibid.

50 Ibid.

51 Ibid.

52 Ibid.

53 Ibid.

54 Ibid.

55 Ibid.

56 Ibid.

57 Ibid.

58 Ibid. 
59 Ibid.

60 Ibid.

61 Lake County, Oregon. Shaw marriage certificate, 13 May 1881.

62 Lake County, Oregon. Shaw marriage license, 26 April 1881 .

63 Ibid.

64 U.S. Department of Interior, Office of Indian Affairs, Klamath Agency Census, 1900 .

65 MCS, 1900

66 Ibid.

67 Ibid.

68 Ibid.

69 Bureau of the Census, Thirteenth Census of the United States, 1910, Oregon, (Manuscript Census Schedules).

70 U.S. Department of Interior, Office of Indian Affairs, Klamath Agency Census, 1901.

71 U.S. Department of Interior, Office of Indian Affairs, Klamath Agency Census, 1902 .

72 Ibid.

73 Ibid.

74 Ibid.

75 Ibid.

76 U.S. Department of Interior, Office of Indian Affairs, Klamath Agency Census, 1903.

77 U.S. Department of Interior, Office of Indian Affairs, Klamath Agency Census, 1906.

78 Ibid.

79 By 1910, the Indian census stopped recording the Indian name of the tribe members. In the Indian census from 1913 to 1915, several children were listed as illegitimate, but there were no references to 
the father's race.

80 Stern, Klamath Tribe, pp. 139-140.

81 Schmeckebier, p. 150 .

82 Linsy Sisemore, ed., History of Klamath County, Oregon (Klamath Falls, 1941), p. 91.

83 Stern, Klamath Tribe, pp. 139-140. Stern notes that analysis of annuity payments from trust shares delivered between November 1907 and January 1908 provide evidence of miscegenation. Payments were received by six married couples, in which both of the spouses were enrolled tribal members. Thirty-nine women and fourteen men who received payments were either single or married to non-enrolled spouses. "While other explanations are plausible, the figures are highly suggestive of a preponderance of off-reservation marriages between Indian women and white men." (p. 137)

84 W.B. Freer, letter of 18 January 1916, to Klamath County Clerk's Office.

85 Ibid.

86 U.S. Department of Interior, Office of Indian Affairs, Klamath Agency Census, 1919 .

87 Ibid.

88 Ibid.

89 U.S. Department of Interior, Office of Indian Affairs, Klamath Agency Census, 1920 .

90 U.S. Department of Interior, Office of Indian Affairs, Klamath Agency Census, 1921.

91 Ibid.

92 Ibid.

93 Ibid.

94 U.S. Department of Interior, Office of Indian Affairs, Klamath Agency Census, 1926.

95 U.S. Department of Interior, Office of Indian Affairs, Klamath Agency Census, 1927.

96 Jerome Fellers, letter of 5 December 1926, to L.D. Arnold. 
97 Ibid.

98 L.D. Arnold, letter of 16 December 1926, to Jerome Fellers.

99 U.S. Department of Interior, Office of Indian Affairs, Klamath Agency Birth Records, 1924-1925.

100 U.S. Department of Interior, Office of Indian Affairs, Klamath Agency Birth Records, 1925-1926.

101 U.S. Department of Interior, Office of Indian Affairs, Klamath Agency Birth Records, 1926-1927.

102 U.S. Department of Interior, Office of Indian Affairs, Klamath Agency Birth Records, 1927-1928.

103 U.S. Department of Interior, Office of Indian Affairs, Klamath Agency Birth Records, 1928-1929.

104 Ibid.

105 U.S. Department of Interior, Office of Indian Affairs, Klamath Agency Census, 1929 .

106 Ibid.

107 Ibid.

108 Ibid.

109 U.S. Department of Interior, Office of Indian Affairs, Klamath Agency Census, 1933.

110 Ibid.

111 U.S. Department of Interior, Office of Indian Affairs, Klamath Agency Census, 1930.

112 Klamath Agency, "Marriages included in 1930 statistical Report," no date. The 1931 list reported ten marriages between Indians and seven between Indians and whites.

113 Klamath Agency Census, 1933.

114 Ibid.

115 Klamath Agency Census, 1930.

116 Stern, Klamath Tribe, p. 126.

117 U.S. Department of Interior, Office of Indian Affairs, Klamath Agency Census, 1932 . 
118 Ibid.

119 Ibid.

120 Klamath Agency Census, 1933.

121 Ibid.

122 Ibid.

123 Ibid.

124 Klamath Agency, "List of Marriages included in 1932 annual statistical report," 15 June 1932. This list noted eight marriages "between Indians" and one marriage "between Indians and Whites."

125 Klamath Agency Census, 1933.

126 Ibid.

127 Klamath Agency, "Marriages During Year 4-1-33 to 3-31-34," no date.

128 U.S. Department of Interior, Office of Indian Affairs, Klamath Agency Census, 1934.

129 U.S. Department of Interior, Office of Indian Affairs, Klamath Agency Census, 1937.

130 Ibid.

131 Ibid.

132 Ibid.

133 Ibid.

134 Stephen Dow Beckham, Land of the Umpqua: A History of Douglas County, Oregon, (Roseburg: Douglas County Commissioners, 1986). Beckham provides a detailed account of the Rogue River Wars and their aftermath in Chapter 5, "Indian-White Relations."

135 Ruby, Guide, p. 48.

136 Ibid., p. 49.

137 Kent, p. 6.

138 Ruby, Guide, p. 50. 
139 Ibid.

140 Zucker, p. 113 .

141 Kent, p. 110 .

142 Ibid., p. 18. Father Adrian Croquet served as Catholic priest to the Grand Ronde Reservation for most of the second half of the nineteenth century. The Catholic Church records of Grand Ronde from 1860 to 1885 offer no conclusive evidence of marriages between Indians and non-Indians.

143 U.S. Department of Interior, Office of Indian Affairs, Siletz Agency Census, 1911.

144 Ibid.

145 U.S. Department of Interior, Office of Indian Affairs, Siletz Agency Census, 1913.

146 U.S. Department of Interior, Office of Indian Affairs, Siletz Agency Census, 1933.

147 Ibid.

148 Ibid.

149 Ibid.

150 Ibid.

151 Ibid.

152 Ibid.

153 Ibid.

154 Ibid.

155 Ibid.

156 Ibid.

157 Ibid.

158 U.S. Department of Interior, Office of Indian Affairs, Siletz Agency Census, 1934.

159 Ibid.

160 zucker, p. 115. 
161 U.S. Department of Interior, Office of Indian Affairs, Siletz Agency Census, 1937.

162 Ibid.

163 Ibid.

164 Ibid.

165 Ibid.

166 Ibid.

167 Ibid.

168 Ibid.

169 Ibid.

170 Ruby, Guide, p. 52 and Zucker, p. 101.

171 Zucker, p. 101.

172 Ibid.

173 Ibid.

174 U.S. Department of Interior, Office of Indian Affairs, Umatilla Agency Census, 1886. B. Coffey, Letter of 14 June 1886 , to Office of Indian Affairs.

175 Umatilla Agency Census, 1886.

176 Ibid.

177 Ibid.

178 U.S. Department of Interior, Office of Indian Affairs, Umatilla Agency Census, 1887.

179 Ibid.

180 U.S. Department of Interior, Office of Indian Affairs, Umatilla Agency Census, 1888. B. Coffey, Letter of July 17, 1888, to Office of Indian Affairs.

181 Umatilla Agency Census, 1888 .

182 U.S. Department of Interior, Office of Indian Affairs, Umatilla Agency Census, 1896. In an August 1896 letter, U.S. Indian Agent George Harkes complained to the office of Indian Affairs about the results of the census by 143 
blaming the "migratory habits of the Indians." He also noted that "it seems impossible to find out the exact number of Indians who are dead or alive."

183 Zucker, p. 101

184 Ibid.

185 Colonel William Parsons, An Illustrated History of Umatilla County (W.H. Lerner: 1902), p. 244 .

186 E. Swartzlander, letter of 4 August 1910, to Office of Indian Affairs.

187 U.S. Department of Interior, Office of Indian Affairs, Umatilla Agency Census, 1910. E. Swartzlander, letter of 12 December 1910, to Office of Indian Affairs.

188 U.S. Department of Interior, Office of Indian Affairs, Umatilla Agency Census, 1914. E. Swartzlander, letter of 24 August 1914, to Office of Indian Affairs.

189 Umatilla Agency Census, 1914

190 U.S. Department of Interior, Office of Indian Affairs, Umatilla Agency Census, 1920.

191 U.S. Department of Interior, Office of Indian Affairs, Umatilla Agency Census, 1929.

192 Ibid.

193 Ibid.

194 Ibid.

195 Ibid.

196 Ibid.

197 U.S. Department of Interior, Office of Indian Affairs, Umatilla Agency Census, 1932.

198 Ibid.

199 Ibid.

200 Ibid.

201 Ibid.

202 Ibid. 
203 Ibid.

204 Ibid.

205 Ibid.

206 Ibid.

207 Ibid.

208 Ibid.

209 U.S. Department of Interior, Office of Indian Affairs, Umatilla Agency Census, 1933.

210 Ibid.

211 Ibid.

212 U.S. Department of Interior, Office of Indian Affairs, Umatilla Agency Census, 1934.

213 U.S. Department of Interior, Office of Indian Affairs, Umatilla Agency Census, 1937.

214 Ibid.

215 Ruby, Guide, p. 56.

216 zucker, p. 97.

217 Ruby, Guide, p. 56 and Zucker, p. 97 .

218 U.S. Department of Interior, Office of Indian Affairs, Warm Springs Agency Census, 1886 .

219 U.S. Department of Interior, Office of Indian Affairs, Warm Springs Agency Census, 1914.

220 Ibid.

221 U.S. Department of Interior, Office of Indian Affairs, Warm Springs Agency Census, 1915.

222 U.S. Department of Interior, Office of Indian Affairs, Warm Springs Agency Census, 1916. The same people appeared in the 1917 census.

223 U.S. Department of Interior, Office of Indian Affairs, Warm Springs Agency Census, 1922 .

224 Ibid. 
225 Ibid.

226 Ibid.

227 U.S. Department of Interior, Office of Indian Affairs, Warm Springs Agency Census, 1926.

228 U.S. Department of Interior, Office of Indian Affairs, Warm Springs Agency Census, 1927.

229 U.S. Department of Interior, Office of Indian Affairs, Warm Springs Birth Records, 1929-1930.

230 U.S. Department of Interior, office of Indian Affairs, Warm Springs Birth Records, 1925-1926, 1926-1927, 1929-1930.

231 Warm Springs Birth Records 1929-1930.

232 U.S. Department of Interior, Office of Indian Affairs, Warm Springs Birth Records, 1931-1932, 1933-1934.

233 U.S. Department of Interior, Office of Indian Affairs, Warm Springs Birth Records, 1928-1929, 1929-1930, 1934-1935.

234 U.S. Department of Interior, Office of Indian Affairs, Warm Springs Agency Census, 1928.

235 Ibid.

236 Ibid.

237 Ibid.

238 U.S. Department of Interior, Office of Indian Affairs, Warm Springs Agency Census, 1929.

239 Ibid.

240 Ibid.

241 Ibid.

242 Ibid.

243 Ibid.

244 U.S. Department of Interior, Office of Indian Affairs, Warm Springs Agency Census, 1930.

245 Ibid. 
246 Ibid.

247 Ibid.

248 Ibid.

249 Ibid.

250 Ibid.

251 U.S. Department of Interior, Office of Indian Affairs, Warm Springs Agency Census, 1931.

252 U.S. Department of Interior, Office of Indian Affairs, Warm Springs Agency Census, 1932 .

253 U.S. Department of Interior, Office of Indian Affairs, Warm Springs Agency Census, 1937. Tom Robinson did not receive a reference to his race. His wife had moved to St. Elizabeth's Hospital in Washington, D.C.

254 Ibid.

255 Ibid.

256 Ibid.

257 U.S. Department of Interior, Office of Indian Affairs, Warm Springs Birth Records, 1938.

258 Ibid. 
REPEAL AND VALIDATION IN THE 1950s:

THE TERMINATION OF OREGON'S RACIAL INTERMARRIAGE BANS

Following World War II, the federal government eyed with increasing interest the idea of discontinuing the national government's role in Indian affairs and transferring power to the states. ${ }^{1}$ This transfer of authority was a concerted shift from the autonomy outlined in the Indian Reorganization Act of 1934, which ended the allotment system. The Reorganization Act also allowed Indian communities to restore tribal governments which had declined during the allotment process and form independent economic developments. The 1934 legislation still guaranteed firm federal dominion over Indian issues. Instead of a policy adhering to these tenets of the Indian "New Deal," an growing number of government and Indian officials lobbied for the assimilation of Native Americans into the larger American society under the auspices of state law. 2

In Termination and Relocation: Federal Indian Policy, 1945-1960, Donald Fixico postulates that President Harry Truman's Fair Deal program, which envisioned a greater level of economic opportunity for many of the country's downtrodden, buoyed the movement to end federal control 
in favor of state authority. ${ }^{3}$ world war II also directly influenced the call for assimilation. Soldiers of many races returned to America emboldened by their war experiences and ready to challenge the racial status quo which conferred second-class citizenship. The less benevolent attitudes of the cold war period conveyed a "widespread distrust of excessive government control and un-American customs or lifestyles. In light of this mood, tribalism, the reservation system and the trust relationship all became highly suspect." 4

After victory in 1948, Truman administration officials began to press with added fervor for Indian assimilation even though many Indian leaders were wary of the financial and social impact of ending federal control. Federal legislators and bureaucrats redcubled efforts to repeal or undercut the Reorganization Act and dismantle the Bureau of Indian Affairs. 5 This thrust toward reducing federal power in Indians' lives became popularly known as "termination." In 1949, the Hoover Commission, a national committee headed by former president Herbert Hoover which evaluated the organization of the executive branch, "recommended termination as a 'firm and continuing policy. "6 The appointment of Dillon Myer as Commissioner of the Bureau of Indian Affairs in 1950 meant that the agency was headed by a man who strongly endorsed termination. 7 Confronted by this persistent body of reformers, many of America's Native Americans faced an 
inevitable transition. "In the eyes of the federal government, Indian Americans had little choice but to become a part of the general populace and to share the same rights and privileges as other citizens," writes Fixico. 8

States with sizable Indian populations girded themselves for the added responsibility from the planned shift. The Governors' Interstate Indian Council was formed in 1948 to enhance cooperation between agencies overseeing Indian populations. In the spring of 1950 , the fourteen-state Governors' Conference on Indian Affairs met in Minneapolis, Minnesota and Salt Lake City, Utah to discuss efforts to integrate Indians into American society. Spurred by the collaborative work of the Conference, Governor Douglas McKay scheduled an Oregon Conference on Indian Affairs for the summer of 1950 which accelerated the pace of examining Oregon's Indian concerns.9 The July event brought together the state's foremost Indian authorities, with officials of the Bureau of Indian Affairs, the superintendents of the four oregon reservations, tribal leaders and state officials congregating to ready themselves for the impending termination.

While national events motivated McKay's decision to host the conference, he served as governor during a period when issues of race relations reverberated through oregon and an engaged civil rights movement emerged to challenge legal and social inequities. World War II brought an unprecedented influx of blacks into Oregon, predominantly 150 
in the Portland area. Drawn by work promised by the war effort, blacks faced discriminatory practices, most acutely in the spheres of housing and employment. Two groups founded in 1944 -- the Committee on Interracial Principles and Practices and the Urban League -- fought against the barriers to equal employment and public accommodations ${ }^{10}$ The state responded to pressure from a growing number of Oregonians by banning several common forms of discrimination. The state legislature passed a fair employment act in 1949. In the same year, the Oregon Supreme Court struck down as unconstitutional the 1923 Alien Land Law, which made it illegal for any person to own land who was ineligible for citizenship. The oregon law was directed toward Asians. In 1951 the legislature banned discrimination in vocational schools, and two years later approved a public accommodations law. 11 McKay himself had outlawed racial discrimination in the oregon National Guard the year before the conference. 12

Amidst these national and state trends, the Governor's Conference on Indian Affairs met on July 14, 1950 at the State Capitol Building. McKay, who later became Secretary of the Interior in President Dwight Eisenhower's first term, said he called the conference to appraise the status of Indians in the state. Furthermore, the gathering represented a chance "to explore the possibility of cooperating with all existing agencies to give the Indian a full and equal citizenship status that has been so long 
delayed and so justly deserved."13

The conference's agenda highlighted the growing sentiment to transfer federal control of Indian matters to the states. The agenda specifically hoped to establish closer ties between the State of Oregon and the Bureau of Indians Affairs. The meeting addressed the possibility of transferring health, educational, and all law enforcement activities from federal to state control. Ultimately, the agenda proposed to establish a mutual objective of abolishing the reservation system and creating an assimilated Indian society. ${ }^{14}$

During the conference, the racial intermarriage ban provoked resentment. Boyd Jackson, a Klamath representative to the meeting, spoke out against several discriminatory Oregon laws, including prohibitions on alcohol use for Indians. But he leveled his harshest criticism, towards the anti-miscegenation statute. "You have also discriminated against us by prohibiting intermarriage among your people. We have to take other means to evade that law. This creates lines of thought other than what the law was designed for," Jackson said. "The same holds true as far as the prohibition law is concerned; it causes us to be dodgers of the law instead of citizens in order to benefit or get what we want," said Jackson. ${ }^{15}$

The conference galvanized the forces who wanted to bring Indians into the Oregon fold without the encumbrance of discriminatory laws. The momentum to rid the state 152 
of these measures gained the Governor's approval.

Described in a biography of Oregon's governors as a "middle of the road Republican" who oversaw "a careful, conservative administration which won him a re-election," McKay provided strong support for the repeal of the state laws which discriminated against Indians. 16

A week after the gathering, E. Morgan Pryse, the Portland-based Area Director of the Bureau of Indian Affairs, wrote a letter to Myer detailing the conference's work. He told Myer that discussions "brought out" that Oregon had a law banning marriage between whites and Indians of more than one-half Indian blood and a liquor prohibition which supplemented a similar federal law. 17 "The Governor indicated that he would bring these matters to the attention of the legislators in the next session and recommend repeal of these statutes," Pryse said. 18

In the July 27, 1950 edition of the Madras Pioneer, Sam Scott, the Indian Correspondent for the central Oregon paper and a conference guest, wrote an article addressed to the enrolled members of the Warm Springs reservation. He reiterated the Governor's and Conference attendees desire to repeal the discriminatory laws. "There seems to be a unanimous agreement on abolishing the law forbidding the use and sale of Iiquor and also the law forbidding intermarriage with the Whites," wrote scott."

In a section titled "Assimilation Eyed," Scott noted that racial intermarriage had occurred in oregon despite 153 
the ban and forecast a thorough assimilation for the nation's Indians.

"Of course it's obvious that the process of assimilation has already begun and has been going on for some time through intermarriage and education and there will come a time when all the American Indians will eventually lose all racial identity as far as the color of the skin is concerned," scott wrote."

In August, Mckay was busy setting up a Governor's Advisory Committee on Indian Affairs, which consisted of twenty-one members from a wide range of Indian interests and agencies. The creation of an advisory committee was a major proposal from the conference. The advisory committee was chaired by A.H. Wright, who was Oregon's Director of Indian Education as well as McKay's representative on the Governors' Interstate Indian council. By November the advisory committee met to formulate its legislative recommendations to the governor. "I would like to remove the miscegenation law from the Oregon statutes. Any Oregon statute that is discriminatory in nature should be abolished," Wright said at the November meeting. "We have to start at home if we expect the federal government to follow our lead in doing away with discrimination." 21

The same month McKay received detailed counsel from Oregon Attorney General George Neuner on the ramifications of the proposed repeal of the comprehensive intermarriage law. In a November 30, 1950 memorandum, Neuner provided McKay with a synopsis of Oregon's two marriage bans. 22 
First, Neuner outlined the comprehensive marriage ban, which was listed as sections 23-1010 through 23-1012 of the Oregon Compiled Laws Annotated. "These laws were enacted by the Oregon legislature in 1866 and have been upon our statutes without amendment since that time," wrote Neuner. 23 He added that the 1866 law was passed subsequently to the first racial intermarriage law in 1862 , which was recorded as section 63-102 O.C.L.A. Neuner pointed out that the 1862 and 1866 laws shared the same language in reference to "negroes or Mongolians." 24

Neuner then included a comparison to other states in the region and described the recent fate of California's anti-miscegenation law. In the 1948 case of Perez v. Lippold, the California supreme court struck down the state's civil law which banned marriages "of white persons with negroes, Mongolians, members of the Malay race, or mulattoes." 25

"I have perused the statutes of neighboring states and have found no such discriminatory restriction against Indians of more than half blood, but did find a similar statute with reference to other races. The supreme court of the state of California in 1948 declared this statute invalid in that the law is discriminatory and irrational and unconstitutionally restricts ngt only religious liberty but the liberty to marry as well."

Neuner predicted that the intermarriage bans could face the same judicial treatment in oregon.

"This case was decided by a divided court, four for the majority and three for the minority and considering the concurring and dissenting opinions of the California court it is not beyond the realm of possibility that if the Oregon sections were brought to a simjlar constitutional test they would meet with the same fate. 
Neuner not only believed the law was vulnerable to

being overturned by the courts but he added a humanitarian rationale for discarding the 1866 law.

"The interest expressed by you with reference to removing the prohibition against a white person intermarrying with a person of more than one-half Indian blood is, I believe, timely. We have recognized the present generation of Indians who populate our state and intermingle with the white people thereof and are citizens in every respect. No doubt the removal of this restriction would do away with the discrimination ;fo bring about a better relationship between the races."

Yet, while Neuner applauded the repeal of the comprehensive marriage law, he mentioned that the 1862 law would still grace the statute books and seemed to suggest that the 1862 law did not necessarily need repeal.

"I doubt the efficacy of an amendment of the first section [of the $1866 \mathrm{law}$ ] above quoted, but believe that a repeal of all of the first three sections could be had without doing violence to the criminal laws of the state. This would leave -- 63-102, O.C.L.A., which prohibits the intermarrying of white persons with persons of one-fourth of more of negro or Mongolian blood."

Before the year was out, Mckay would be lobbied by another Indian organization to repeal the intermarriage law. In December 1950, the influential Wright, who was chairman of the Oregon Indian Council, wrote to McKay that the council unanimously decided that all discriminatory statutes pertaining to Indians must be removed from the state's law books. $^{30}$ Wright's letter stated that the Oregon Indian Council petitioned "the Governor to initiate such a program by making the following recommendations in his message to the 1951 legislature." 31 The laws the council 
specified for repeal were those denying the purchase or possession of liquor by Indians, plus the 1866 marriage law.

In a January 2, 1951 letter to Tom McCall, McKay's secretary and a future oregon governor, wright said that he had written the bills to repeal the laws and that he was currently working with the statute Revision Council to prepare the legislation for the upcoming session. 32 "As soon as I get these bills in shape to present to our legislature, perhaps it would be advisable to call a meeting of the council to discuss the bills as they are written and ways and means of getting them passed," Wright suggested. "It is sometimes easy enough to get a bill introduced in the legislature, but it is often difficult to get them passed." 33 A caucus of legislators supporting the bills was held in the Governor's office in the buildup to the session. 34 Two Oregon legislators on the Governor's advisory committee who were from districts with notable Indian populations -- Senator Philip Hitchcock, a Republican from Klamath Falls, and Representative Sprague Carter, a Republican from Pendleton -- took the lead in helping the bills through the legislature. 35

The wrangles over the miscegenation bill which punctuated the forty-sixth legislative session paralleled many of the arguments which erupted during the fourth session in 1866. Once again, national events fueled the debate over interracial marriage in oregon, with a 
controversial constitutional amendment replaced by the congressional and federal embrace of termination. Eighty-five years later, several legislators still could not publicly countenance these nuptials. Unions between whites and blacks generated the most overt hostility. Though opponents from the two eras shared similar revulsion for these marriages, they offered quite different arguments during the debates. Instead of the nineteenth-century alarm that racial intermarriage would assist the cause of black equality, several legislators intimated in the 1951 session that the sanction of racial intermarriage would hinder the political and social advancement of blacks. The legislative tussle highlighted the prominent role Mckay held in securing the repeal of the anti-miscegenation laws.

Senate Bill 110 was introduced on January 22 by Hitchcock and Senator Warren Gili; a Republican from Lebanon in Linn County. The bill called for the repeal of the entire 1866 law known as sections 23-1010 through 23-1012 of the criminal code. Furthermore, the bill amended section 63-102 of the civil code under marriage to rid the section of a provision barring marriages between a white person and a "negro or Mongolian" of one-fourth or more blood. The bill also amended a section of Oregon law which Neuner did not address in his memo to McKay. Section 9-902 of the Suits in Equity section of the Code of Civil Procedure, which dated from 1862, said that "all marriages which are prohibited by law - . on account of either of them being 158 
one-fourth or more of Negro blood, shall, if solemnized within this state, be absolutely void."36 senate Bill

110 removed all racial barriers to marriage that the oregon statute books contained.

The bill was referred to the Senate Committee on Law, where it met stiff opposition. A February 1 front page Oregonian article titled "Mixed-marriage proposal beaten" outlined the aggressive stance taken by both proponents and opponents of the repeal. 37 The committee the previous day "balked at permitting intermarriage between negroes and whites." 38 By a vote of four to three, the committee rejected a "do pass" motion on the bill. In testimony before the committee, Hitchcock stated that "the time has passed when any legislature should prohibit any marriage for racial reasons."39 But the committee was swayed by the position of Senator Thomas Mahoney, a Democrat from Portland, who told reporters that he was not opposed to white-Indian marriages, but that he could not countenance "negro and white" marriages. "It's a crime to unborn children," stated Mahoney. 40

News of the committee defeat prompted a response from the federal government's top Indian official in Oregon. Pryse of the Bureau of Indian Affairs reminded Hitchcock in a February 6 letter that the BIA would help during hearings on the repeal legislation. "From newspaper reports we understand that committee action taken on the so-called miscegenation statutes was unfavorable. Probably this 
resulted from the fact that individuals other than those with Indian blood were included in the proposed repeal of said statutes," wrote Pryse, who displayed racial tolerance beyond the confines of his specific jurisdiction. "Although this office is primarily concerned with the repeal of discriminatory legislation affecting people with Indian blood, certainly if we are to be democratic in our actions the repeal of the miscegenation statutes should be all inclusive." 41

The next month, the same committee reconsidered the bill and by the switch of one vote, S.B. 110 moved toward the full Senate. In a March 13 oregonian article titled "Marriage law clears hurdle," the bill gained approval by a four to three margin. 42 Senator William Walsh, a Republican from coos Bay and the committee chair, altered his earlier vote and approved the measure. But the opposition to the bill was still adamant. "Mahoney, who was denounced by the Young Democrats of Multnomah County for his opposition to the bill, said he is still against it on the grounds that 'it might agitate matters," the Oregonian reported. 43 Senator Frank Hilton, another opponent of the bill and a Republican from Portland, cautioned that "stirring up the issue now won't do any good. " 44

Gill, the bill's co-sponsor, told the oregonian that he wished to express his solidarity with the call by oregon Indians to repeal the law for its discriminatory content. 160 
"Marriages are made in heaven. How can we legislate against God?" Gill declared. 45

The vote on March 20 before the full senate showed the legislative body as a whole more sympathetic to the bill than the close committee vote indicated. A March 21 Oregonian story which ran across the middle of the front page was headlined "Senate Okehs Removal of Miscegenation Ban." 46 The story said that the senate voted twenty-one to seven "to wipe out all oregon legislation banning interracial marriages." 47 The article on the vote in the March 21 oregon Journal noted that "mixed marriages received the stamp of approval in the oregon Senate." 48

In his comments on the senate floor, Hitchcock "characterized the racial ban [as] 'an archaic statute, a disgrace to the state of oregon, which violates the constitution and the laws of God." 49

Hitchcock found an ally from southern Oregon in Senator Marie Wilcox, a Republican from Grants Pass in Josephine County. "She pointed out that many oregon veterans are marrying girls of dark skin from foreign lands," the Journal noted. 50 The March 21 Klamath Falls Herald and News added that Wilcox had been asked by several veterans to support the bill "so they could bring their wives home." 51

But Gill still attempted to quell concern with the repeal by stating that he did not foresee "any rush" to county clerks offices by interracial couples. 52 In committee testimony, Gill adopted a progressive role, 161 
speaking of marriages as heaven-made. Before the full

Senate, Gill spoke with a more ambivalent tone. "I can't say I favor such marriages but I don't disfavor them. It's a personal right," Gill said."

The Oregonian described Mahoney, Hilton and Senator Eugene Marsh, a Yamhill County Republican, as the leaders of the "fight against the bill."54 The trio "all said they had no objections to the action of principals in white and colored marriages, but that they considered such marriages unfair to the resulting children."55

The Salem Statesman quoted Marsh as calling the repeal "unfair to the children who are the offspring" of interracial marriages. 56 "They are outcasts," he added. 57 Marsh "discounted contentions that the feelings of principals in such marriages should be the paramount consideration, and cited various authorities establishing regulation of marriages as a prerogative of the legislature." 58

Hilton justified his stance by noting that Portland defeated a civil rights ordinance in November 1950 by a vote of 77,084 to 60,969 . The vote, he offered, "was evidence that people did not want mingling of the races." 59 Hilton added that "he objected only to whites marrying Negroes, and others indicated that was the only racial conflict in their minds." 60

The Journal stated that Mahoney believed interracial marriages "posed a great moral and social problem."61 
Furthermore, he stressed that the bill would "set civil rights back 20 years." 62 When Mahoney was accused of discriminating against "colored" people, he retorted that "it is just as discriminatory against whites as against colored persons."63 Despite black support for a civil rights ordinance in Oregon's largest city, Mahoney believed that "this is the kind of legislation Negroes do not want. "64

Mahoney felt so strongly opposed to the bill that he requested the inclusion of the following statement in the Journal of the Senate.

"Involving as it does a grave moral issue this bill has caused me great concern.

Commencing with my 1939 term as a senator I have fought for civil rights, for the right of all people, black as well as white, to social justice, but I fear the agitation of this matter of intermarriage will retard the progress of civil rights.

Countless times when urging the passage of civil rights legislation I have encountered the claim that the proponents of civil rights were ultimately proposing intermarriage between the races. This I have denied.

I do not subscribe to the theory that the blood of one race is different than the blood of another, that any one race is superior to the other, or that either race is inferior to the other--but I do not believe in intermarriage.

I have the highest respect for countless citizens of the colored race--I am proud to count them among my friends, but I believe ${ }^{5} 5_{5}$ would be doing them a disservice to vote for this bill."

The day after the senate vote, S.B. 110 entered the House and was reported back in early April with a recommendation for passage by the committee on state and 
Federal Affairs. But on the third reading of the bill on April 5, the bill was referred to the Committee on Judiciary on the motion of Representative Raymond Coulter, a Republican from Grants Pass. 66 The Committee on Judiciary substituted two House bills, H.B. 663 and 664 , for S.B. 110. Senate Bill 110 was found to have a defective title and so the split was procedurally necessary. 67 House Bill 663 amended section 9-902 while H.B. 664 tackled two sections of marriage law by amending section 63-102 of the 1862 law and repealing the 1866 law listed as sections 23-1010 through 23-1012.

On April 12, the House passed H.B. 663 by a vote of fortyone to three. 68 The three dissenters were all Republicans. The vote was conducted with three members absent and thirteen legislators excused. House Bill 664 was adopted the same day by a vote of forty-four to four, with the three earlier opponents joined by another Republican colleague. 69

With the House hurdles cleared, the senate once again tackled the issue of racial intermarriage. By a unanimous vote of thirty yeas, the Senate passed H.B. 663 on April 27.70 The companion bill, however, faced a stiffer test. On April 26, the Committee on Law sent to the Senate floor a majority report signed by four members which called for passage of the bill. On the same day, a minority report signed by Mahoney and Marsh recommended against the bill's passage. ${ }^{71}$ The senate adopted the majority report and 
passed H.B. 664 on April 30 by a vote of the nineteen to eight. 72 Besides the trio of Hilton, Mahoney and Marsh, three Republicans and two Democrats opposed the bill. Mckay signed both bills into law in early May.

Following the session Commissioner Myer praised McKay for his work in supporting and signing the bills which removed Oregon's discriminatory legislation towards Indians. "You and the people of your state are to be commended upon this forward step toward the integration of Indians into our American society," wrote Myer. 73

"The enactment of this legislation is an important milestone for these first Americans on the road to full independence and freedom from governmental paternalism of any sort. In the achievement of this goal the informed efforts of local, state and Federal officials--as well as of the Indians themselves and of other $7 q^{\text {rivate }}$ citizens--are all essential," Myer added.

Speaking to the Governor's Advisory Committee on Indian Affairs in September 1951, chairman Wright underscored the struggle to finalize the repeal of the Indian laws and lauded McKay's vital role in securing passage.

"I think you all know what a battle it took to get these bills passed.. . I followed this legislation through from start to finish, and these bills were passed because we had the backing and support of Governor McKay and his assistant, Tom McCall. When some of we lesser mortals say we want something done, people are not likely to pay much attention to us, but when we say the Goverpor of oregon supports this action, they will listen to us."

In the first half of the 1950s, the Eisenhower administration continued to pursue termination. Governor McKay had become Eisenhower's Secretary of the Interior in 1953 and in this capacity served as the chief 
administrator of termination proceedings from 1953 to 1956. In the early part of August 1953, Congress adopted House Concurrent Resolution 108, which stated that Congress wished to terminate its relationship with tribes. 76 Later the same month, Congress passed Public Law 83-280, which effectively transferred criminal and civil jurisdiction from tribal and federal authorities to the states. 77 In Oregon, the Warm Springs reservation obtained exemption from the transfer but the other reservations fell under state control. 78 Due to controversy over tribal membership and the disposition of land, the Klamaths did not receive final termination until 1961. 79

The Oregon Legislature addressed racial intermarriage twice in the 1950 s following the 1951 session and in the wake of the implementation of the federal termination policy. The 1951 legislative action repealed the interracial marriage bans while laws in 1955 and 1959 validated any interracial marriage which was prohibited by the 1866 and 1862 statutes.

In 1955, Representative Maurine Neuberger, a Democrat from Portland, sponsored House Bill 351, which validated all marriages previously banned under the 1866 law described in section 23-1010 through 23-1012 of the O.C.I.A. The bill passed both houses of the legislature unanimously. In 1953, Oregon revised the state's laws in a new format so that the O.C.I.A. was replaced by the Oregon Revised Statutes. Neuberger's legislation became O.R.S. 106.210 . 166 
Specifically, the legislation validated "any marriage in all other respects legal and regular but heretofore void by reason of Oregon Laws of 1866, Section 1 . . prohibiting marriage between a white person and one having Negro, Chinese, Kanaka or Indian blood."80 The children of those previously banned marriages were also deemed legitimate.

However, Oregon did not completely straighten out its interracial marriage statutes until the 1959 session. Four representatives sponsored House Bill 639, which added another section to O.R.S. 106.210 validating marriages which were illegal under the 1862 law to the earlier section implemented in 1955 which validated marriages banned by the 1866 law. Representative Doug Heider, a Republican from Salem and a co-sponsor of the bill, told the House that the legislation was necessary because of an "oversight in an earlier law legalizing interracial marriages in oregon." 81 While the senate passed the bill unanimously, the House passed the bill by a vote of fifty-four to two. The 1959 legislation validated all marriages "between a white person and one having Negro or Mongolian blood" which were previously barred by the 1862 law. 82 After almost one hundred years, the 1959 legislature erased all barriers to interracial marriage from the Oregon lawbooks with a final stamp of approval. 83 
1 Donald Fixico, Termination and Relocation: Federal Indian Policy, 1945-1960 (Alburquerque: University of New Mexico Press, 1986), p. ix. Fixico examines the movement to assimilation in the Preface of the book. Spurred by the General Citizenship Act of 1924, which conferred citizenship on all of America's Indians, the assimilation policy was galvanized by World War II.

2 Ibid.

3 Ibid., p. 45

4 zucker, p. 134

5 Fixico, pp. 45, 49 and 54.

6 Zucker, p. 77 .

7 Ibid.

8 Fixico, p. 45 .

9 Douglas McKay, "Summary of the Activities of the Governor's Committee on Indian Affairs as of April 1, 1952," Office of Governor Douglas McKay, administrative correspondence, Indian Affairs, 1950-1952, Oregon State Archives. The influence of the Governors' Interstate Indian Council on the Oregon conference in July 1950 is found in Theodore Taylor, The States and Their Indian Citizens (Washington D.C.: United States Department of Interior, Bureau of Indian Affairs, 1972), pp. 41-42.

10 Gordon Dodds, "The Civil Rights Movement in Oregon, 1944-1953," Author's personal papers, p. 4.

11 McLagan, p. 179.

12 Dodds, "Civil Rights Movement," p. 14.

13 "Minutes of Governor's Conference of Indian Affairs," 14 July 1950, Office of Governor Douglas McKay, administrative correspondence, Indian Affairs, 1950-1952, Oregon State Archives.

14 "Summary of the Activities of the Governor's Committee on Indian Affairs as of April 1, 1952."

15 "Minutes of Governor's Conference," p. 3. When Boyd Jackson referred to people taking "other means to evade" the marriage law, he hinted to the possibility that 
area couples traveled to states where white-Indian marriages were not barred in any way. Klamath Agency marriage records from the 1940s and early 1950s show a great many couples traveling to Washoe County, Nevada to marry in Reno. However, a survey of these records does not reveal a couple consisting of a white and an Indian of more than one-half blood making the journey. Census records do show that white-Indian couples traveled to Reno for their nuptials even though many of the Indian newlyweds were considerably less than one-half Indian blood. Despite a distance of approximately 250 miles from Klamath Falls, Reno has been a historically popular wedding site and honeymoon location for generations of Klamath county couples regardless of racial classification.

16 George Turnbull, Governors of Oregon (Portland: Binfords and Mort, 1959), pp. 94-95.

17 E. Morgan Pryse, letter of 21 July 1950, to D.S. Myer, Office of Governor Douglas McKay, administrative correspondence, Indian Affairs, 1950-1952, Oregon state Archives. Federal law prohibited the introduction of liquor into Indian country.

18 Ibid.

19 Madras Pioneer, 27 July 1950.

20 Ibid.

21 "Minutes of the Governor's Advisory Council on Indian Affairs," 29 November 1950, Office of Governor Douglas McKay, administrative correspondence, Indian Affairs, 1950-1952, Oregon State Archives.

22 George Neuner, memorandum of 30 November 1950, to Douglas McKay, Office of Governor Douglas McKay, administrative correspondence, Indian Affairs, 1950-1952, Oregon State Archives. The memorandum to McKay was not Neuner's first examination of the 1866 law. In a January 31 , 1945 Attorney General Opinion signed by Neuner but prepared by Assistant Attorney General Grace Bottler, Neuner told Douglas County District Attorney H.A. Canaday that the county should not issue a license for the marriage of a man of three-quarters Hawaiian blood and a white woman. Under the 1866 law known as sections 23-1010 through 23-1012 of the O.C.L.A., Neuner's office believed "it is quite clear that under the submitted state of facts, the county clerk should not issue a marriage license to these applicants." 22 Op. Atty Gen (1944-46) 101 . 
23 Ibid.

24 Ibid.

25 Ibid.

26 Ibid.

27 Ibid.

28 Ibid.

29 Ibid.

30 A.H. Wright, letter of 27 December 1950, to Douglas McKay, Office of Governor Douglas McKay, administrative correspondence, Indian Affairs, 1950-1952, Oregon State Archives.

31 Ibid.

32 A.H. Wright, letter of 2 January.1951, to Tom McCall, Office of Governor Douglas McKay, administrative correspondence, Indian Affairs, 1950-1952, Oregon state Archives.

33 Ibid.

34 "Minutes of Governor's Committee on Indian Affairs meeting," 11 September 1951, Office of Governor Douglas McKay, administrative correspondence, Indian Affairs, 1950-1952, Oregon State Archives.

35 Ibid.

36 Oregon Compiled Laws Annotated, Section 9-902, (San Francisco: Bancroft-Whitney, 1940), pp. 117-118.

37 Portland Oregonian, 1 February 1951, p. 1 .

38 Ibid.

39 Ibid.

40 Ibid.

41 E. Morgan Pryse, letter of 6 February 1951, to Philip Hitchcock, Office of Governor Douglas McKay, administrative correspondence, Indian Affairs, 1950-1952, Oregon State Archives.

42 Oregonian, 13 March 1951, p. 8 . 
43 Ibid.

44 Ibid.

45 Ibid.

46 Oregonian, 21 March 1951, p. 1.

47 Ibid.

48 Oregon Journal, 21 March 1951, p. 18.

49 oregonian, 21 March 1951.

50 Journal, 21 March 1951.

51 Klamath Falls Herald and News, 21 March 1951, p. 2 .

52 Salem Statesman, 21 March 1951, p. 5.

53 Ibid.

54 Oregonian, 21 March 1951.

55 Ibid.

56 Statesman, 21 March 1951.

57 Ibid.

58 Oregonian, 21 March 1951.

59 Ibid.

60 Ibid.

61 Journal, 21 March 1951.

62 Statesman, 21 March 1951.

63 Oregonian, 21 March 1951.

64 Statesman, 21 March 1951.

65 Oregon. Journal of the Forty-Sixth Regular Session of the senate, 20 March 1951 .

66 Oregon. Journal of the Forty-Sixth Regular Session of the House, 4 April 1951 .

67 Oregonian, 28 April 1951.

68 Journal of the House, 12 April 1951. 
69 Ibid.

70 Journal of the Senate, 27 April 1951.

71 Ibid., 26 April 1951.

72 Ibid., 30 April 1951.

73 D.S. Myer, letter of 5 June 1951, to Douglas McKay, Office of Governor Douglas McKay, administrative correspondence, Indian Affairs, 1950-1952, Oregon State Archives.

74 Ibid.

75 "Minutes of Governor's Committee on Indian Affairs meeting," 11 September 1951, Office of Governor Douglas McKay, administrative correspondence, Indian Affairs, 1950-1952, Oregon State Archives.

76 Zucker, p. 158 .

77 Ibid.

78 Ibid.

79 Fixico, pp. 117 and 181

80 Oregon Laws, 1955, p. 907.

81 Oregonian, 7 April 1951.

82 Oregon Laws, 1959, p. 937.

83 Ibid. 
CONCLUSION

For nearly ninety years, Oregon prohibited racial intermarriage. The practice was viewed as such an affront to society that even the attempt of a banned marriage was punishable with a jail sentence. By the end of the 1950s Oregon not only repealed the two major laws but validated any marriages which had been solemnized before the repeal. Yet fourteen years after the laws' repeal and two years before the United States Supreme Court struck down all intermarriage statutes in the Loving v. Virginia case, the Oregon Supreme Court in 1965 confronted the 1866 law. Similarly to the Paquet case in 1921, the legal tussle in Crawford v. Karr centered on an estate disputed between an alleged wife and a sibling who contested the marriage using the law.

Merle Crawford, a Klamath Indian, had died in December 1961. Two years later, his sister, Rosetta Betty Karr, filed a petition to administer his estate, which was granted to her. ${ }^{1}$ Three days after the judgment, Vivian Sisson Crawford filed a petition to revoke Rosetta's privilege because Vivian said she was Merle's widow. ${ }^{2}$ A Klamath County Circuit Court judge denied Vivian's motion, saying that no legally recognizable marriage was ever conducted. Court records stated that Vivian was a one-quarter Cherokee Indian who was not an enrolled member of any 173 
Klamath Reservation tribe. Merle was described as an enrolled member of Scotch-Irish and Indian descent. The couple had known each other since childhood, both being raised on the Klamath Reservation. "In February 1933, the parties being in love, agreed to live together as husband and wife in the [Klamath Reservation] home of [Vivian's] mother." 3 In 1945, the couple "each executed affidavits to the effect that they had orally agreed to become man and wife and had considered themselves to be man and wife since september 1933."4 These affidavits were delivered to the Klamath Agency superintendent, who recorded them in a marriage book. Furthermore, they held themselves out to the community as man and wife.

But the Klamath County judge said the couple did not comply with any tribal customs recognized by the Klamaths as constituting a marriage ceremony. The judge added that the 1866 law known as section 23-1010 of the O.C.L.A. was in force in 1933 and found that Vivian "must be taken as being a white person" and Merle was an Indian of "more than one-half blood." 5 This finding by the Klamath county court is contradicted by $\mathrm{Klamath}$ census information from the 1920s which lists Merle and Rosetta as one-half Indian over a several year period.

The Supreme court held that the repeal of the law in 1951 and subsequent validation of interracial marriages in 1955 and 1959 supported the Crawford's relationship. "Therefore, the marriage was not prohibited by any 
anti-miscegenation statute." 6 Despite some misgivings about the validity of a marriage ceremony, the supreme Court concluded that prima facie evidence of a marriage existed and reversed the trial court's decision by appointing Vivian as administrator of the estate.

After more than one hundred years of legal prohibition and uncertainty, the right to marry a person of any race was confirmed by the Oregon Supreme Court. Plainly, interracial marriages existed, even thrived, while the racial restrictions were imposed. The Indian censuses showed that people skirted the law for decades. In hundreds of cases, local and federal officials documented these unions and either openly or tacitly condoned them. But despite the maneuvers available to evade the law and the understanding shown by some authorities, the barriers spread an unmistakable message of intolerance. With the Crawford case, the century-long legal saga ended as the decision finally erased the notion that it was a criminal act to marry a person of another race. 


\section{ENDNOTES FOR CONCLUSION}

Crawford v. Karr, 242 Or. 259 (1965), p. 260.

2 Ibid.

3 Ibid.

4 Ibid., p. 261.

5 Ibid., p. 262 .

6 Ibid. 
BIBLIOGRAPHY

PRIMARY SOURCES

Public Documents

Bureau of the Census. Oregon. Oregon Historical Society. Seventh Census of the United States. 1850.

Eighth Census of the United States. 1860.

Ninth Census of the United States. 1870 .

Tenth Census of the United States. 1880 .

Twelfth Census of the United States. 1900.

Thirteenth Census of the United States. 1910 .

Office of Douglas McKay. Administrative Correspondence. Indian Affairs. 1950-1952. Oregon State Archives.

Office of Indian Affairs. Oregon Historical Society. Klamath Agency Census.

Siletz Agency Census.

Umatilla Agency Census.

Warm Springs Agency Census.

Church Records

Munnick, Harriet Duncan, ed. Catholic Church Records of the Pacific Northwest. Jacksonville. Portland: Binford and Mort, 1984 . - Catholic Church Records of the Pacific Northwest. Oregon City. Portland: Binford and Mort, 1984 .

- Catholic Church Records of the Pacific Northwest. Portland. Portland: Binford and Mort, 1986. 
- Catholic Church Records of the Pacific Northwest. Roseburg. Portland: Binford and Mort, 1986 .

- Catholic Church Records of the Pacific Northwest. St. Louis. Portland: Binford and Mort, 1982 .

- Catholic Church Records of the Pacific Northwest. St. Paul. Portland: Binford and Mort, 1979 .

- Catholic Church Records of the Pacific Northwest. Vancouver. St. Paul, Oregon: French Prairie Press, 1972 .

Donation Land Claims

Genealogical Forum of Portland, Oregon. Genealogical Material in Oregon Donation Land Claims, vol. 1. Portland: Genealogical Forum of Portland, 1962.

Legislative Records

Oregon Compiled Laws Annotated. San Francisco: BancroftWhitney, 1940 .

Oregon. Journal of the Fourth Regular Session of the House. 1866.

Oregon. Journal of the Fourth Regular Session of the Senate. 1866 .

Oregon. Journal of the Forty-Sixth Regular Session of the House. 1951 .

Oregon. Journal of the Forty-Sixth Regular Session of the Senate. 1951 .

Oregon Laws. 1866 .

Oregon Laws. 1955.

Oregon Laws. 1959.

Marriage Certificates

Clark County, Washington.

Douglas County, Oregon. 
Jackson County, Oregon.

Newspapers

Albany State Rights Democrat.

Klamath Falls Herald and News.

Madras Pioneer.

The Oregon Statesman.

Portland Oregonian.

Salem Daily Record.

Salem Statesman.

Oregon Legal Cases

22 Op. Atty Gen (1944-46) 101 .

Crawford v. Karr 242 Or. 259 (1965).

In Re Estate of Fred Paquet, 101 Or. 393 (1921).

Vandolf v. Otis, 1 Or. 153 (1854).

SECONDARY WORKS

Books

Alterman, Hyman. Counting People: The Census In History. New York: Harcourt, Brace and World, 1969.

Anderson, Margo. The American Census: A Social History.

New Haven: Yale University Press, 1988.

Bancroft, Hubert Howe. History of Oregon, vol. 1, 1834-1848, vol. 29 in The Works of Hubert Howe

Bancroft. San Francisco: The History Company, 1886.

Beckham, Stephen Dow. The Indians of Western Oregon: This Land was Theirs. Coos Bay, Oregon: Arago Books, 1977. 
- Land of the Umpqua: A History of Douglas County, Oregon. Roseburg: Douglas County Commissioners, 1986.

Brosnan, Cornelius. Jason Lee: Prophet of the New Oregon. New York: The Macmillan Company, 1932.

Brown, Jennifer. Strangers in Blood: Fur Trade Company Families in Indian Country. Vancouver: University of British Columbia, 1980 .

Carey, Charles. General History of Oregon Prior to 1861 , vol. 1. Portland: Metropolitan Press, 1935.

Clarke, S.A. Pioneer Days of Oregon History. Portland: J.K. Gill Company, 1905.

Cohen, Felix. Felix Cohen's Handbook of Federal Indian Law. Charlottesville, Virginia: The Michie Company, $\overline{1982}$.

Deloria, Jr., Vine and Clifford Lytle. The Nations Within: The Past and Future of American Indian Sovereignty. New York: Pantheon Books, 1984 .

Dodds, Gordon. The American Northwest: A History of Oregon and Washington. Arlington Heights, Illinois: The Forum Press, 1986. 1977

Oregon: A History. New York: W.W. Norton,

Fixico, Donald. Termination and Relocation: Federal Indian Policy, 1945-1960. Alburquerque: University of New Mexico Press, 1986.

Fogdall, Alberta Brooks. Royal Family of the Columbia: Dr. John McLoughlin and His Family. Portland: Binford and Mort, 1978 .

Harring, Sidney. Crow Dog's Case: American Indian sovereignty, tribal law, and United States law in the nineteenth century. Cambridge: Cambridge University Press, 1994.

Hussey, John. Champoeg: Place of Transition. Portland: Oregon Historical Society, 1967.

Johansen, Dorothy and Charles Gates. Empire of the Columbia: A History of the Pacific Northwest. New York: Harper and Row, 1957. 
Johannsen, Robert. Frontier Politics and Sectional Conflict: The Pacific Northwest on the Eve of the Civil War. Seattle: University of Washington Press, 1955 .

Johnson, David Alan. Founding the Far West: California, Oregon and Nevada, 1840-1890. Berkeley: University of California Press, 1992 .

Jordan, Winthrop. White Over Black: American Attitudes Toward the Negro, 1550-1812. Chapel Hill; University of North Carolina Press, 1968.

Judson, Katherine Berry. Early Days in Old Oregon. Portland: Metropolitan Press, 1935.

Loewenberg, Robert. Equality on the Oregon Frontier: Jason Lee and the Methodist Mission, 1834-1843. Seattle: University of Washington Press, 1976.

Lynch, Vera Martin. Free Land for Free Men: A Story of Clackamas County. Portland: Artline Publishing, 1973.

McLagan, Elizabeth. A Peculiar Paradise: A History of Blacks in Oregon, 1788-1940. Portland: The Georgian Press, 1980 .

Meyer, Melissa and Russell Thornton. "Indians and the Numbers Game: Quantitative Methods in Native American History." In New Directions in American Indian History, ed., Colin Calloway. Norman: University of Oklahoma Press, 1988.

Miller, Emma Gene. Clatsop County, Oregon: Its History, Legends, and Industries. Portland: Binford and Mort, 1958 .

Montgomery, Richard. The White Headed Eagle: John McLoughlin, Builder of an Empire. New York: The Macmillan Company, 1934.

Morris, Thomas. Southern Slavery and the Law, 1619-1860. Chapel Hill: The University of North Carolina Press, 1996.

Parsons, Colonel William. An Illustrated History of Umatilla County. W.H. Lerner, 1902 .

Ruby, Robert and John Brown. A Guide to the Indian Tribes of the Pacific Northwest. Norman: University of Oklahoma Press, 1986. 
- Indians of the Pacific Northwest: A History.

Norman: University of Oklahoma Press, 1981.

Schmeckebier, Lawrence. The office of Indian Affairs:

Its History, Activities and Organization. Baltimore:

The Johns Hopkins Press, 1927.

Schlesser, Norman Dennis. Bastion of Empire: The Hudson's Bay Company's Fort Umpqua. Oakland: Oakland Publishing, 1973 .

Stern, Theodore. The Klamath Tribe: A People and Their Reservation. Seattle: University of Washington Press, 1965 .

Taylor, Theodore. The Bureau of Indian Affairs. Boulder: Westview Press, 1984.

- The States and Their Indian Citizens. Washington D.C.: United States Department of Interior, Bureau of Indian Affairs, 1972.

Turnbull, George. Governors of Oregon. Portland: Binford and Mort, 1959.

Van Kirk, Sylvia. Many Tender Ties: Women in Fur-Trade Society, 1670-1870. Norman: University of Oklahoma Press, 1980 .

Wilkinson, Charles. American Indians, Time and the Law: Native Societies in a Modern Constitutional Democracy. New Haven: Yale University Press, 1987.

Williamson, Joel. New People: Miscegenation and Mulattoes in the United States. New York: The Free Press, 1980 .

Woodward, Walter Carleton. The Rise and Early History of Political Parties in Oregon, 1843-1868. Portland: J.K. Gill Company, 1913 .

Zucker, Jeff and Kay Hummel and Bob Hogfoss. Oregon Indians. Portland: Western Imprints, $198 \overline{3}$.

Journal Articles

Duniway, David and Neil Riggs. "Oregon Archives, 1841 1842." Oregon Historical Quarterly 60 (June 1959). 
Elliott, T.C. "A Hudson's Bay Company Marriage

Certificate." Oregon Historical Quarterly 10

(September 1909).

Hussey, John. "The Women of Fort Vancouver." Oregon

Historical Quarterly 92 (Fall 1991).

Richard, K. Keith. "Unwelcome Settlers: Black and Mulatto

Pioneers, Part I." Oregon Historical Quarterly 84

(Spring 1983).

"Unwelcome Settlers: Black and Mulatto Oregon Pioneers, Part II." Oregon Historical Society 84

(Summer 1983).

Stern, Theodore. "The Klamath Indians and the Treaty of 1864." Oregon Historical Quarterly 57 (September $1956)$.

Theses and Dissertations

Hajda, Yvonne. "Regional Social Organization in the Greater Lower Columbia, 1792-1830." Ph.D. diss., University of Washington, 1984.

Head, Harlow Zinser. "The Oregon Donation Claims and Their Patterns." Ph.D. diss., University of Oregon, 1971.

Kent, William Kent. "The Siletz Indian Reservation 1855-1900." Master's Thesis, Portland State University, 1973 .

\section{Unpublished Work}

Dodds, Gordon. "The Civil Rights Movement in Oregon, 19441953." 
Despite the existence of harsh racial intermarriage laws in oregon, interracial couples who wished to wed could find solace by crossing the columbia. The state of Washington never enacted marriage provisions which included racial restrictions. So, Oregon residents, especially like those in Portland who lived just across the border, did have a way of evading the law.

The issue of ridding the state of intermarriage limitations sparked the interest of several Multnomah County residents, who were perhaps especially motivated by living in such close proximity to a state which did not place racial restraints on marriage. Legislation to repeal the intermarriage bans was introduced by a Multnomah County Senator in 1893 after consultation with a local black minister. 1 The full senate defeated the proposal. 2 In 1917, a Multnomah County legislator once again filed legislation to remove the racial restrictions to marriage. Republican D.C. Lewis said that he introduced the bill "at the request of my colored constituents." 3 He supported the repeal by noting "if a white man loves a colored woman or a Chinese woman, let him marry her."4 Following a 
committee recommendation for defeat, the full House killed the legislation without a vote. ${ }^{5}$ These were the only repeal attempts until the efforts in 1951 .

I examined the clark County, Washington marriage certificates and applications for the following periods: $\operatorname{mid}-1921$ to $\operatorname{mid}-1922 ; 1925 ; 1930 ;$ and mid-1939 to mid-1940. These documents contained a space for "Color or Race." Each twelve-month period that I studied had at least one example of an Oregon couple whose racial percentages exceeded Oregon's law securing a marriage in Washington. A couple who lived in downtown Portland were married in Vancouver on September 6, 1921, by Minister A.D. Skagg. The groom, William Bibbens, was listed on the marriage certificate as a thirty-nine-year-old "colored" railroad waiter born in Texas. ${ }^{6}$ Dollie Foss was a thirty-year-old native of Illinois. It was the first marriage for each of the couple.

The next month, on October 7, Minister Skagg performed a ceremony in Vancouver for a "part Hawaiian" man from Portland and a white woman from Estacada. 7

Twenty-three-year-old F.F. Newcastle was born in Honolulu to parents born in California and Hawaii. The previously single Newcastle worked as a musician. Born in Oregon, twenty-four-year-old Ava Bateson was a housewife marrying for the second time.

The following month Skagg wed a Chinese man and a white woman in Vancouver. On November 16 , John Lee, who 185 
was born in Oregon to parents born in China, married Lou Erma Delmore, a California native. 8 Twenty-four-year-old John worked as a baker and lived in Portland's Del Mar Hotel. Delmore, a twenty-three-year-old Portland resident, was described as a housewife.

On the day before Christmas in 1921, Minister Chester Bennett wed thirty-six-year-old Andrew Charles and thirty-four-year-old Pearl Smith. Listed as an "Indian," Charles worked at a sawmill.9 Described as "white," Smith worked as a housekeeper. 10 From the marriage certificate, I am unable to determine whether Andrew Charles was an Indian of more than one-half blood. Compared to the previous couples, the marriage by this Portland couple may well have fallen within the legally prescribed limits. However, the next Portland couple wed in Vancouver would have been barred from solemnizing their marriage in Oregon. James Amaka, listed by race as a Hawaiian, married Eva Marie Whitaker, listed as white, on July 23, 1925. 11 A musician, the twenty-four-year-old Amaka had parents who were both born in Hawaii. Whitaker was fifteen-years-old and a native of Tennessee. Interestingly, the couple were married by Murry Fitzgerald, a minister who listed his residence as Portland.

In 1930, two Portland couples who exceeded the racial strictures of Oregon's law were married in Washington. Victor Hooker and Helen Hedsfeth exchanged vows in Camas on May 31, 1930. Hooker was listed on the marriage 186 
certificate as a member of the "Colored Race" while his bride was described as a member of the "White Race."12 A native Oregonian whose parents were born in England, Hooker worked as a "nursery-man."13 Hedsfeth, who was born in Canada, was a housewife.

On December 19, a Portland couple were married in Vancouver. The names are indecipherable but the racial information is clear. The twenty-four-year-old groom, who was born in Hawaii to Hawaiian parents, was listed as "brown" in the color category. ${ }^{14}$ The bride was a twenty-year-old white woman.

The marriage applications from late 1939 and early 1940 unearthed two Portland area interracial couples coming to Washington on their wedding day. James Andrews and Enola Sandy of Portland signed the marriage affidavit on December 14,1939 . In this document witnessed by clark County Deputy Auditor Catherine Kerwin, the couple swore that they did not conflict with any of the marriage restrictions of the state of Washington. The interracial aspect of their relationship was clearly spelled out on the application. A native of Alabama, Andrews was a twenty-eight-year-old "Negro" who worked as a jack hammer operator. 15 Sandy was a twenty-nine-year-old "White" housewife who was born in Oregon. 16

Jameson Long was a thirty-year-old Chinese clerk born in Portland who married twenty-three-year-old Dolly Kamp, a white waitress, who was also born in Portland. Long's 187 
parents were both born in China. Signed by another deputy auditor, the "marriage statistics" form filled out by the couple was dated January $12,1940.17$

These nine couples suggest that further study of the Clark County records will provide more evidence of Oregon couples sidestepping the Oregon law by crossing the Columbia. 


\section{A DISGUSTING SPECTACLE:}

PORTLAND'S RESPONSE TO THE AOKI-EMERY WEDDING

On March 15, 1909, the Portland Morning Oregonian printed a story from San Francisco detailing the engagement of Gungiro Aoki, a Japanese student, and Helen Gladys Emery, the white daughter of Archdeacon John A. Emery of the Episcopal Church. The impending Bay Area marriage "has not only attracted worldwide attention, but unpleasant threats have been made as to what will happen if the Japanese persists in carrying out his plan of marrying the lady in question." 1

By March 22, the paper was running a front page story on growing resentment against the marriage from the San Francisco suburb where the couple lived separately. A change of venue was suggested. "As for Aoki's alleged statement that the wedding would take place during the present week at Portland, [Helen's mother], Mrs. Emery declared that she knew of no such plans." 2

The Oregonian of March 24 told its readers that "Aoki expects to wed in Portland." ${ }^{3}$ A reporter in San Francisco interviewed Aoki, who said that the wedding was to take place within the week, but the exact date was still not determined. The anonymous reporter resorted to harsh 
editorializing. "America and his associations with

Americans have made very little impression on him. He has absolutely no sense of moral obligation . . He belongs altogether to the dishwashing type, lacking, however, the servility and good manners of that class." 4

On the evening of March 24, Helen Emery and her mother boarded "the Oregon express" with plans to arrive in Portland in two days. 5 A series of vertical headlines told readers that "Jap's fiancee on train for Oregon" and that both mother and daughter "expect tolerance in North." 6 The Emerys found little support in Portland. "They will find that the avenues to marriage have been fully and effectively shut off," a March 26 Oregonian article noted. 7 The Multnomah County Clerk's office had issued instructions to all its deputies on March 25 to refuse the couple a marriage license.

"'Not only refuse them a license, but if they attempt to argue the matter, throw them out of the office,' was Mr. Field's terse and unmistakable order to his office force." 8 The District Attorney's Office even intimated that if the couple was met by a public commotion, Aoki and Emery could face arrest under public nuisance laws. 9 Both of these county offices promised to carry out the threats to deny a marriage license even though their position did not follow the letter of the marriage law. "While the question is raised as to whether the couple can legally secure a license in Portland there is no question that they will be refused one. The Oregon law 190 
prohibits the intermarriage of white persons with negroes or Mongolians. Now, the Japanese disclaim being Mongols, but this claim does not meet the approval of the accepted authorities on race genealogy. At any rate the county Clerk and District Attorney will place their own construction on that law, and they are,ggreed that a Jap and a Mongolian are one and the same."

Despite an unequivocal Washington law which allowed people of any race to marry, Clark County District Attorney James stapleton stressed that he would exert pressure to stop the marriage. "I most emphatically oppose the intermarriage of Japanese and whites and while there is no legal impediment to such a marriage in this state, I should do all I can to prevent such a union," stapleton said. 11 The clark County auditor presented a less confrontational stance. "The laws of the state of Washington permit the marriage of Orientals and whites, and I shall have to grant the license if asked for here," stated M.D. Kies. 12

Even though personally opposed to the marriage, the mayor of Tacoma, John Linck, adopted a conciliatory tone.

There will be no demonstration against the Japanese and the Emery girl if they come to Tacoma to be married - . We will not tolerate mob interference with people in the peaceable pursuit of their rights . . Personally I am opposed to the mixture of these races, but I do 1 not think it is a question for any one to interfere in."

The Oregonian's editorial page on March 26 spared no contempt for the marriage in a column titled "A Disgusting spectacle."14

"The statutes of Oregon may not precisely forbid this marriage, but public sentiment is revolted by it. And the spirit of the statutes, if not the letter, condemns it. - Under the laws of Oregon we think it would be 191 
permissible to issue a marriage license to these erratic or misguided people. But we wonder what official can so far overcome his repugnance as to issue it; or what person, authorized by law to solempize marriages, will officiate at the mongrel ceremony."

The editorial saved its most scathing attack on the Emerys for the last paragraph of the piece.

The mere suggestion of such a marriage creates infinite disgust. Evidently the daughter who entertains it and the mother who supports it are religious and social perverts, who enjoy the notoriety."

On the afternoon of March 26, the mother and daughter spent, not surprisingly, less than ninety minutes in Portland, waiting only for a connecting train to Tacoma. "They learned while en route here from San Francisco on the Oregon Express that their welcome in Portland would be anything but cordial" wrote the oregonian." 17 But their short stay passed without incident.

"Fully 100 persons, who had gathered at the Union Depot to see the Emerys, were disappointed. As the Oregon Express drew up at the depot there was a craning of necks. It was generally believed the Jap was with them and that they might see a marriage license at the County clerk's Office. "18

Instead, the couple were married in a Seattle Episcopal Church on March 27, without any commotion.

Two years later a bill was introduced in the Oregon Legislature which would have amended the marriage law to criminalize marriages with "Hindus" and "Japanese" but no action nor vote was taken on the proposal. 19 


\section{ENDNOTES FOR APPENDIX A}

1 McLagan, p. 163

2 Ibid.

3 Ibid., p. 199

4 Ibid., p. 164 .

5 Ibid.

6 Clark County, Washington. Bibbens marriage certificate, 6 September 1921 .

7 Clark County, Washington. Newcastle marriage certificate, 7 October 1921 .

8 Clark County, Washington. Lee marriage certificate, 16 November 1921.

9 clark County, Washington. Charles marriage certificate, 24 December 1921 .

10 Ibid.

11 Clark County, Washington. Amaka marriage certificate, 23 July 1925.

12 clark County, Washington. Hooker marriage certificate, 31 May 1930.

13 Ibid.

14 Clark County, Washington. Name unrecognizable marriage certificate, 19 December 1930 .

15 Clark County, Washington. Andrews marriage affidavit, 14 December 1939.

16 Ibid.

17 Clark County, Washington. Long marriage affidavit, 12 January 1940 .

ENDNOTES FOR APPENDIX B

1 Portland Oregonian, 15 March 1909. 
2 Ibid., 22 March 1909, p. 1.

3 Ibid., 24 March 1909, p. 1.

4 Ibid.

5 Ibid., 25 March 1909, p. 1.

6 Ibid.

7 Ibid., 26 March 1909, p. 1.

8 Ibid.

9 Ibid.

10 Ibid., p. 8 .

11 Ibid.

12 Ibid.

13 Ibid.

14 Ibid., p. 10.

15 Ibid.

16 Ibid.

17 Ibid., 27 March 1909, p. 1.

18 Ibid.

19 McLagan, p. 164. 